\title{
CONSEQÜÊNCIAS DA AUTOFECUNDAÇÃO INDESEJÁVEL NA PRODUÇÃO DE SEMENTES HÍBRIDAS DE MILHO
}

\author{
Édila VILELA DE RESENDE Von PINHO \\ Engenheiro Agrônomo
}

Orientador: Prof. Dr. Sílvio Moure Cícero

Tese apresentada à Escola Superior de Agricultura "Luiz de Queiroz", da Universidade de São Paulo, para a obtenção do título de Doutor em Agronomia, Área de Concentração: Fitotecnia.

PIRACICABA

Estado de São Paulo - Brasil

Junho - 1995 
Ficha catalografica preparada pela Secto de Livros da Divisaio de Biblioteca e Documentaçäo - FCLQ/USF

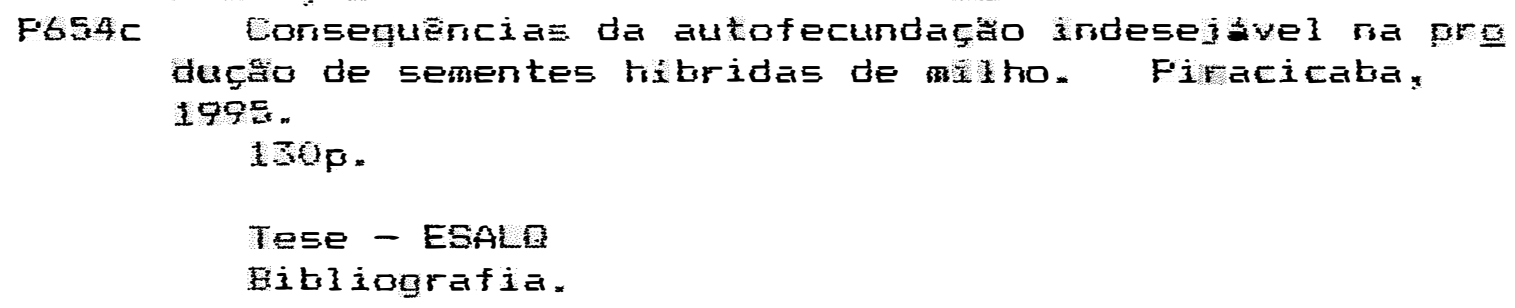
duça de sementes tibridas de milto. Firacicaba, $199^{\circ}$. $130 \mathrm{p}$.

TESE - ESALO

Bibliografia.

3. Milho - Eemente ribrida - Dualidade 2. Milho Semente híbide - Autofecundaçö Z. Semente hibrida Froducto I. Escola Superior de Agricultura Luiz de Queiroz, Firacicaba 
Aos meus pais José e Neuza Ao meu esposo Renzo pelo incentivo constante $e$ à minha filha Iolanda, motivo de alegria. 


\section{AGRADECIMENTOS}

Ao Prof. Dr. Sílvio Moure Cícero, pela orientação, amizade e constante apoio.

Aos professores Dr. Francisco Ferraz de Toledo, Dr. Walter Rodrigues da Silva e Dr. Júlio Marcos Filho pelos ensinamentos transmitidos e dedicação.

Aos Engenheiros Agrônomos Ana Dionísia C. L. Novembre e Helena M. C. P. Chamma pela amizade e apoio durante o curso.

Ao Prof. Dr. Décio Barbin pela atenção e valiosa colaboração no planejamento da análise estatística.

À Empresa Cargill Agrícola S/A - Divisão de Sementes Híbridas, através do Gerente de Pesquisas, Delmo Diogo Rodrigues, pelo apoio, sugestões e suporte oferecido para a condução deste trabalho.

Ao Engenheiro Agrônomo Renzo Garcia Von Pinho, pelo apoio, sugestões valiosas e pelo carinho dedicado.

Aos colegas do curso de pós-graduação pela amizade e incentivo, em especial à Maria Cristina Spínola, Monaliza Diniz, Marco Antonio de Sousa, Antonio D. Alexandre, Claudio Cavariani, Raimundo Velazco, Denise A.C. Billia, Clotilde Pinheiro Ferri e Denise Dias.

À CAPES (Coordenadoria de Assistência à Pesquisa) pelo suporte financeiro.

Aos professores e funcionários da ESALQ/USP, especialmente do Departamento de Agricultura pela amizade e convívio. 
Aos funcionários da Cargill Agrícola S/A- Campinas-SP, pelo apoio na condução de alguns experimentos de campo.

A todos, que de alguma maneira contribuíram para a realização desse trabalho. 


\section{ÍNDICE}

Página

Resumo viii

Summary $x$

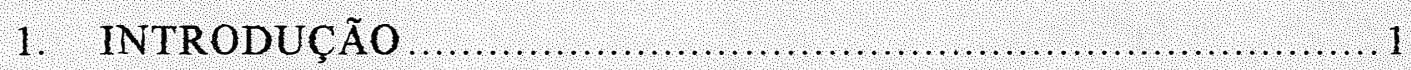

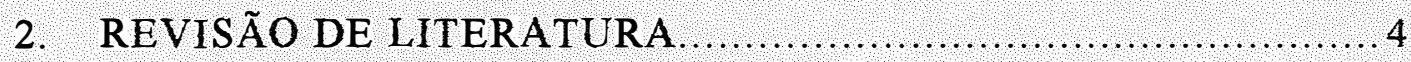

2.1. Heterose versus Produção ...................................... 4

2.2. Tipos de Híbridos e sua Performance $\ldots \ldots \ldots \ldots \ldots \ldots \ldots \ldots \ldots . \ldots \ldots$

2.3. Produção de Sementes Híbridas .............................. 12

2.4. Pureza Genética .............................................. 18

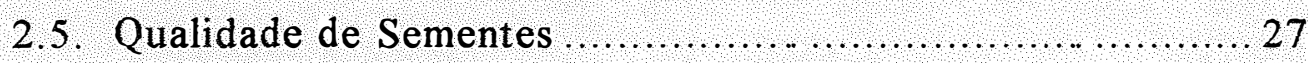

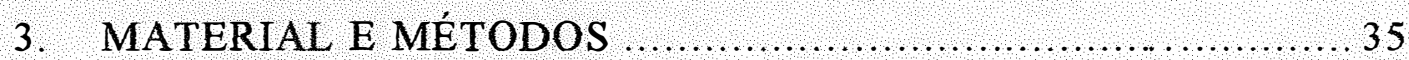

3.1. Produção de Sementes ........................................... 35

3.2. Avaliação da Qualidade Fisiológica .......................... 37

3.2.1. Teste de Germinação .................................. 37

3.2.2. Envelhecimento Artificial ......................... 38

3.2.3. Teste de Frio ...................................... 38

3.2.4. Teste de Condutividade Elétrica .................... 39

3.2.5. Emergência em Campo............................... 39

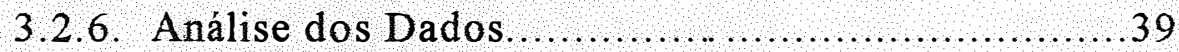


3.3. Ensaio em Campo........................................... 40

3.3.1. Determinações Pré-Colheita .......................... 45

3.3.2. Determinações Pós-Colheita ......................... 46

3.3.3. Análise dos Dados.................................47

3.4. Estudo de Metodologia para Avaliação

da Pureza Genética .......................................... 47

3.4.1. Avaliação em Sementes............................. 48

3.4.2. Avaliação no Estádio de Plântulas..................... 48

3.4.3. Avaliação de Plantas no Campo .......................49

3.4.4. Análise dos Dados.................................. 50

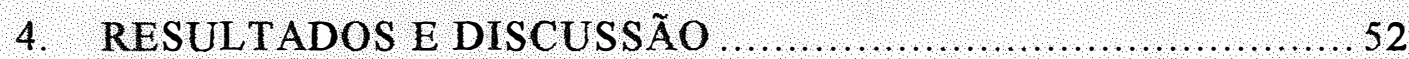

4.1. Avaliação da Qualidade Fisiológica ......................... 52

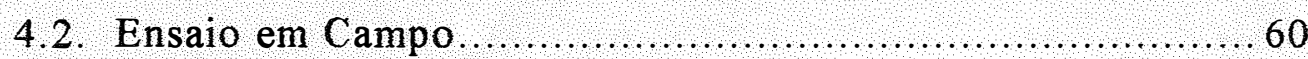

4.3. Avaliação da Pureza Genética.................................99

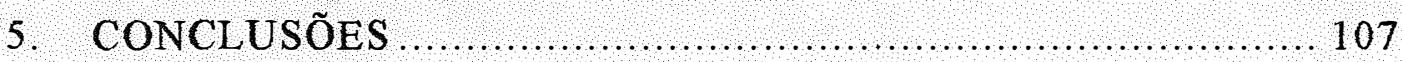

REFERÊNCIAS BIBLIOGRÁFICAS ............................... 108

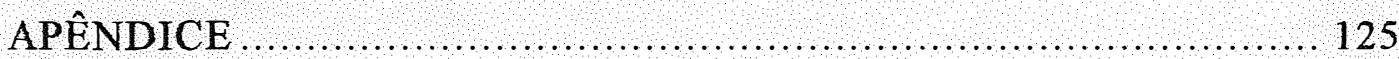




\title{
CONSEQÜÊNCIAS DA AUTOFECUNDAÇÃO INDESEJÁVEL NA PRODUÇÃO DE SEMENTES HÍBRIDAS DE MILHO
}

\author{
Autora: Édila Vilela de Resende Von Pinho \\ Orientador: Prof. Dr. Sílvio Moure Cícero
}

\section{RESUMO}

O presente trabalho foi realizado com o objetivo de avaliar a qualidade físiológica e componentes da produção, de lotes de sementes híbridas apresentando misturas com sementes provenientes do parental fêmea autofecundado em diferentes taxas. Estudaram-se metodologias para avaliação da pureza genética com o objetivo de identificar sementes provenientes de autofecundação no processo de produção de milho híbrido.

Para este estudo, foram produzidas sementes dos híbridos C 901, C 808 A, C 425 e C 701, sendo o primeiro um híbrido simples, o segundo triplo e os dois últimos duplos, e sementes provenientes dos parentais fêmeas autofecundados. Após obtenção dos materiais, sementes provenientes dos parentais fêmeas autofecundados foram misturadas com sementes híbridas nas taxas de $0,5,10,20$ e $100 \%$ e avaliadas em sua qualidade fisiológica, no Laboratório de Análise de Sementes da Escola Superior de Agricultura "Luiz de Queiroz", da Universidade de São Paulo. Para avaliação dos parâmetros, estande inicial e final, alturas de planta e de espiga, porcentagem de plantas quebradas e acamadas e produção de grãos, foram conduzidos experimentos em 
Ituverava, Guaíra, Piracicaba e Paranapanema; nos dois primeiros, a semeadura foi realizada na segunda época de cultivo denominada "safrinha" e nos dois últimos a semeadura deu-se em época normal.

A avaliação da pureza genética foi realizada em sementes, plântulas, plantas com 5-7 folhas, no florescimento, na colheita e em póscolheita, baseando-se principalmente, em características morfológicas.

A análise dos dados e a interpretação dos resultados permitiram concluir que: a) Lotes de sementes de milho do híbrido simples, apresentando mistura com sementes provenientes do parental fêmea autofecundado, apresentam redução na qualidade físiológica; b) Considerando os quatro híbridos estudados, houve redução média de $0,5 \%$ na produção de grãos para cada $1 \%$ de sementes provenientes de autofecundação misturadas nas sementes híbridas; c) A redução no rendimento de grãos dos híbridos estudados, decorrente de misturas com sementes dos parentais fêmeas autofecundados, depende, sobretudo, do rendimento das plantas provenientes de autofecundação e da capacidade de compensação das plantas híbridas; d) Em alguns híbridos, é possivel separar, com precisão, através de características morfológicas, as plantas autofecundadas das plantas híbridas. A época mais adequada para avaliação da pureza genética varia entre os híbridos. 


\title{
CONSEQUENSES OF UNDESIRABLE SELFINGS IN THE HYBRID CORN SEED PRODUCTION
}

\author{
Author: Édila Vilela de Resende Von Pinho \\ Adviser: Prof. Dr. Silvio Moure Cícero
}

\section{SUMMARY}

The objective of the present work was to evaluate the physiologic quality and main yield components of hybrid seed lots presenting mixes with seed obtained from female parents with different degrees of selfing. It was also studied the methodologies to evaluate the genetic purity, with the objective of identifying the contaminant selfed seed provoked by bad detasseling of the female parent, in the hybrid seed production process.

For this study it was produced hybrid seed and female parent selfed seed of the single cross hybrid C 901 , the three way hybrid C 808 A and the double cross hybrids C 425 and C 701 . Different ammounts of selfed seed of the parental females were mixed with the correspondent hybrid seed, to obtain samples with $0,5,10,20$ and $100 \%$ of selfed seed. These seed samples were evaluated for physiological quality in the seed lab of the Escola Superior de Agricultura "Luiz de Queiroz", from Universidade de São Paulo. In the evaluation of the yield components the traits evaluated were the initial and final stand, the plant and ear height, the percentage of root and stalk lodged 
plants and yield obtained by grain weight. The field trials were installed in the "safrinha" planting season at Ituverava and Guaira, and the normal planting season at Piracicaba and Paranapanema.

The evaluation of genetic purity was made at stage of seedlings, at young plants (5-7 leave plants), at flowering, at harvesting and, in the ears, after harvesting. The main criteria for evaluation was observation of several morphologic characteristics.

The analysis of data and interpretation of the results allowed: a) Corn single cross hybrid lots presenting mixes of female parent selfed seed showed reduction in physiological quality; b) The grain yield in the average hybrids studied presented a reduction of $0,5 \%$ for each $1,0 \%$ female parent selfed seed mixes with the hybrid seed; c) The reduction in the average grain yield in the hybrids studied provoked by mixture of female parent selfed seed were dependent, basically, by the yield and plant vigor of the plant obtained by the selfed seed; the capability of compensation by the other hybrid plants in the plot; d) Using morphologic characteristics, it is possible to separete the selfed plants from the hybrid seed with a good precision for some hybrids. The stage of development better suitable for the evaluation of the genetic purity varies from hybrid to hybrid. 


\section{INTRODUÇÄO}

Com o advento do milho híbrido houve um grande avanço na agricultura, principalmente no que se refere ao aumento do rendimento. $O$ exito da performance dos híbridos é o resultado do efeito heterótico, obtido pelo cruzamento de linhas diferentes geneticamente e que possuem boa capacidade combinatória.

Para garantir os beneficios da heterose, é de suma importância o controle da polinização em um campo de produção de sementes Este controle tem por objetivo garantir a hibridação através da polinização cruzada entre os parentais. Para isso há necessidade de evitar a ação do pólen produzido pelo parental fêmea, seja através do despendoamento ou pela utilização da macho esterilidade. A ação do pólen do parental fêmea proporciona um potencial de ocorrência de autofecundação, constituindo a principal fonte de contaminação genética em campos de produção de sementes. Como conseqüência, sementes provenientes do parental fêmea autofecundado podem se apresentar menos vigorosas, dando origem a plantas mais fracas e improdutivas, afetando diretamente o rendimento de grãos e comprometendo o ganho genético esperado com o cruzamento, uma vez que a endogamia observada no processo de autofecundação conduz à perda do vigor. 
Em programas de controle de qualidade de empresas produtoras de sementes de milho, vistorias são realizadas nos campos de produção durante o despendoamento para garantir a remoção dos pendões liberadores de pólen do parental fêmea, com o objetivo de assegurar a pureza genética do material a ser obtido.

Os padrões de campo para produção de sementes híbridas de milho relacionados à porcentagem tolerada de pendões do parental fêmea liberadores de pólen no Brasil são os mesmos adotados nos EUA e relatados por WYCK (1988). Entretanto não têm sido estabelecidos padrões de tolerância para porcentagem de sementes provenientes do parental fêmea autofecundado em lotes de sementes híbridas, com exceção feita a algumas empresas norte americanas produtoras de sementes de milho, que têm empregado padrões durante a condução da análise de pureza genética.

A baixa disponibilidade de resultados de pesquisa mostrando o efeito de misturas de sementes de milho provenientes do parental fêmea autofecundado, em lotes de sementes híbridas, na qualidade fisiológica das sementes e na produção de grãos, provavelmente tem contribuído para a inexistência dos referidos padrões Além da deficiência de trabalhos relacionados ao assunto, a falta de metodologias para identificação das sementes provenientes do parental fêmea autofecundado, misturadas às sementes híbridas comerciais contribui para a inexistência de padrões. Esta identificação torna-se mais fácil quando ocorre expressão de xênia, que possibilita o estudo de segregações genéticas na semente. Assim, sementes de 
natureza híbrida poderão ser reconhecidas por certos caracteres, como cor, condicionadas pelo genótipo do pólen, atuando no embrião ou no endosperma. No entanto, quando não ocorre expressão de xênia, há necessidade do uso de técnicas aplicáveis na indústria sementeira.

Este trabalho teve como objetivo avaliar a qualidade fisiológica e alguns componentes da produção de diferentes sementes híbridas de milho apresentando misturas com sementes provenientes do parental fêmea autofecundado em diferentes níveis. Procurou também estudar metodologias para identificação de sementes provenientes do parental fêmea autofecundado. 


\section{REVISATO DE LITERATURA}

\subsection{Heterose versus Produção}

A introdução do milho híbrido, por volta de 1920 , constituiu-se num dos maiores impulsos à agricultura moderna. $\mathrm{O}$ híbrido apresenta, na maioria das vezes, acréscimos em relação a uma série de caracteres quando comparado à média dos parentais (HAGEMAN et al., 1967; SURESH \& HANNA, 1975; FAKOREDE \& AGBANA, 1983). A heterose, foi empregada por SHULL em 1909 para expressar os efeitos benéficos da hibridação ou seja, o maior vigor da geração $F_{1}$ em relação à média dos pais ou ao pai mais produtivo (HALLAUER \& MIRANDA FILHO, 1981b). JUGENHEIMER (1959) definiu a heterose como um fenômeno em virtude do qual o cruzamento entre variedades produz um híbrido superior quanto ao rendimento e vigor. Em geral, o principal efeito esperado está relacionado com o aumento do rendimento. Contudo, uma série de caracteres agronômicos são melhorados e explorados através da heterose (ALLARD, 1971).

WHALEY (1944), relatou que a heterose refere-se a um estímulo fisiológico, produzido pela união de gametas diferentes, que resulta em maior rendimento, maior resistência a insetos e doenças, aumento no número e tamanho dos frutos, em decorrência do aumento da eficácia 
metabólica do híbrido. A mesma linha de pensamento foi abordada por JONES (1922) ao observar elevações no tamanho e no número de frutos devidas à heterose, resultado de maior número de células com ritmo mais acelerado de divisão e atividade celular. $\mathrm{O}$ mesmo autor citou, ainda, como manifestação da heterose, a eficiência biológica, como a atividade reprodutora e capacidade de sobrevivência. RUSSELL (1974) informou que o aumento da produtividade dos híbridos de milho sobre as variedades de polinização aberta, geralmente, é em torno de $25-35 \%$.

Vários autores tentaram elucidar o mecanismo da heterose, demonstrando interações gênicas aparentemente benéficas (SCANDALIOS et al, 1972, SCHWARTZ \& LAUGHNER, 1973). Várias teorias genéticas e bioquímicas foram propostas para explicação deste mecanismo; entretanto nenhuma delas é totalmente aceita (HAGEMAN et al, 1967).

Uma das hipóteses que procura explicar a heterose é a da dominância. Esta, sugerida por KEEBLE \& PELLEW (1910) e por BRUCE (1910), considera que os genes dominantes são favoráveis ao vigor enquanto, os recessivos, são desfavoráveis. Alguns pesquisadores como SHULL (1911) e East \& Hayes, citados por JUGENHEIMER (1959) discordaram desta hipótese uma vez, assim sendo, seria possível obter linhas puras tão vigorosas quanto os híbridos.

East \& Hayes, citados por JUGENHEIMER (1959), atribuíram ao vigor da geração $F_{1}$ a condição heterozigótica, ou seja, a heterose será tanto maior quanto maior for o número de genes em heterozigose. EAST 
(1936) propôs a teoria de atividade intra-alelomórfica com ausência de dominância. Esta implica em uma série de alelomorfos em um ponto A como, por exemplo, $\mathrm{A}^{1}, \mathrm{~A}^{2}, \mathrm{~A}^{3}$ e $\mathrm{A}^{4}$. Supõe-se que cada alelomorfo de ordem mais alta tenha atividade positiva com os mais baixos. Assim, ocorre maior eficácia fisiológica em $\mathrm{A}^{1} \mathrm{~A}^{4}$ do que em $\mathrm{A}^{1} \mathrm{~A}^{2}$ e a base da heterose seria a atividade complementar dos alelomorfos em um mesmo lugar. Entretanto, ainda existem divergências quanto à elucidação da heterose. Muitas pesquisas, relacionadas a métodos de melhoramento, desenvolvimento de linhagens, seleção de testadores e outros, têm sido conduzidas para se determinar a base genética da heterose (FEHR, 1987; HALLAUER et al., 1988). Além disso, o grau de dominância, a epistasia e a interação genótipo-ambiente são fatores que dificultam a elucidação da heterose (MANGELSDORF, 1928).

Na cultura do milho, a idéia sugerida por SHULL (1909), para obtenção de linhas puras e a sua utilização na produção de sementes híbridas expressando a heterose, é válida até hoje (MIRANDA FILHO \& VIEGAS, 1987; HALLAUER \& MIRANDA FILHO, 1981a).

Assim, o primeiro requisito em um programa de hibridação de milho é a obtenção de linhas autofecundadas. Estas são relativamente homozigóticas e obtidas mediante autofecundações e seleções. Os primeiros experimentos com autofecundação em milho foram conduzidos por DARWIN (1877), onde foram observadas reduções no vigor das plantas. Já McCLUER (1892) informou a respeito da obtenção de híbridos enfatizando que o cruzamento aumentava o vigor e o rendimento e que a autofecundação produzia 
plantas parcialmente estéreis, observou, ainda, que a segunda geração de sementes híbridas apresentava rendimento mais baixo do que a primeira geração. Entretanto, foi SHULL (1909) quem começou os trabalhos com autofecundação em milho visando a produção de milho híbrido, indicando a superioridade do cruzamento entre linhas autofecundadas. RICHEY (1922) reuniu dados de produtividade de 244 cruzamentos de cultivares de milho e observou que $86,5 \%$ foram superiores à média dos pais, $13,5 \%$ apresentaramse abaixo e $68,8 \%$ excederam os pais superiores. SHULL (1946) abordou a importância econômica da hibridação no melhoramento do milho.

No Brasil, a produção de sementes híbridas de milho, desenvolveu-se, principalmente, na região centro-sul, favorecendo a ampliação do número e capacidade produtiva das companhias privadas produtoras de sementes. Atualmente, vários híbridos comerciais adaptados para diferentes regiões são recomendados aos agricultores, após ensaios conduzidos em todo o território nacional (FERREIRA FILHO \& PERES, 1988).

\subsection{Tipos de Híbridos e sua Performance}

Já foi abordado que as linhas autofecundadas de milho são inferiores em vigor quando comparadas às variedades de polinização aberta. $O$ principal aproveitamento das linhas é na produção comercial de milho híbrido e, com o arranjo destas, é possível a produção de vários tipos de híbridos. Os tipos de híbridos comerciais mais utilizados são o simples, o duplo e o triplo. 
As sementes de híbridos simples são produzidas necessariamente, em plantas autofecundadas relativamente pouco produtoras de sementes e pólen justificando o alto custo de sua produção. Por este motivo, a produção de híbrido simples, sugerida por SHULL (1946), não foi imediatamente aplicada. Contudo, as pesquisas em melhoramento genético tem resultado em linhagens melhoradas com performance suficiente para proporcionar produção de sementes de híbridos simples comercial exeqüível. Uma das maneirạs encontradas, para reduzir o custo de produção de sementes de híbridos simples, é a da produção de híbridos simples modificados. Neste caso utiliza-se, como progenitor feminino, o híbrido de duas progênies afins da mesma linhagem e, como progenitor masculino, outra linhagem ou híbrido de progênies afins. Em qualquer caso, o custo de produção de sementes é reduzido porque o progenitor feminino apresenta maior vigor que se manifesta em maior produção. Desde a metade da década de 60 os híbridos simples estão substituindo os duplos nos EUA e, atualmente, a quase totalidade dos híbridos cultivados são de cruzamento simples (SCHNELL, 1975).

No Brasil, grande parte dos híbridos recomendados são duplos devido, principalmente, à baixa tecnologia utilizada pela maioria dos agricultores. Entretanto, nos últimos anos, tem havido uma tendência de aumento na oferta dos híbridos simples e triplos no mercado, visando atender os agricultores mais tecnificados.

As sementes de híbridos duplos são produzidas nas plantas de híbridos simples que, geralmente, produzem grandes quantidades de sementes e 
pólen Com isso o número de plantas produtoras de sementes pode ser maior do que o das plantas produtoras de pólen em campos de cruzamento. A sugestão de utilização de linhas puras combinadas em cruzamentos duplos, de menor custo tecnológico, foi proposta por JONES (1922).

JUGENHEIMER (1959) abordou que as plantas de híbridos simples, utilizadas para a produção de híbridos duplos, resistem mais às condições adversas do tempo e reduzem os riscos com a produção de sementes, quando comparados às das linhagens utilizadas na produção de híbridos simples. Os híbridos duplos e triplos apresentam maior estabilidade produtiva do que os híbridos simples, por se constituírem em mistura de genótipos; assim, terão menor variação em ambientes distintos devido à variabilidade genética da população (EBERHART \& RUSSELL, 1969).

Os híbridos triplos, provenientes de um híbrido simples, como parental feminino, e uma linhagem como parental masculino, têm sido utilizados por apresentarem maior uniformidade do que os híbridos duplos sem elevações apreciáveis no custo das sementes (SCHNELL, 1975). Entretanto, a superioridade dos híbridos simples para a produção de grãos, em relação aos demais, foi apresentada por JUGENHEIMER (1958), WEATHERSPOON (1970) e LOPEZ-PEREZ (1977).

Em condições similares de índice de área foliar, penetração de luz e população de plantas, vários componentes de produção de um híbrido duplo, seus dois híbridos simples parentais e suas linhagens parentais foram estudados por JOHNSON \& TANNER (1972). Sob a mesma população de 
plantas, os híbridos simples foram superiores às suas respectivas linhagens parentais quanto à produção de grãos, rendimento vegetativo, taxa de acúmulo de matéria seca, período de formação de grãos e índice de área foliar. Sob mesmo índice de área foliar e porcentagem de penetração de luz, as linhagens igualaram-se aos seus respectivos híbridos simples em produção vegetativa. Para os outros componentes de produção estudados, os híbridos simples foram superiores às linhagens parentais. O híbrido duplo se manteve, geralmente, em posição intermediária para a maioria dos componentes estudados; a porcentagem de sólidos solúveis nos colmos das linhagens foi superior à encontrada nos híbridos, o que pode ter ocasionado baixa taxa de enchimento de grãos.

Os híbridos triplos, algumas das vezes, mostram-se superiores aos simples quanto à performance média (SCHNELL, 1975). CRAIG (1977) enfatizou que, se a epistasia não estiver presente, a produção de híbridos duplos e triplos pode ser prognosticada pela produção média de híbridos simples parentais.

EBERHART (1969) desenvolveu trabalho com o objetivo de estudar a estabilidade de produção de híbridos simples. $O$ autor comentou que a estabilidade de produção pode ser desenvolvida através de técnicas apropriadas de seleção, incluindo seleção recorrente para produção e prolificidade nas populações parentais. Abordou as necessidades de instalação de ensaios sob diferentes condições ambientais e de existência de variação genética entre híbridos simples em relação à estabilidade de produção. 
Nesta mesma linha de trabalho, WEATHERSPOON (1970) comparou a produção de grãos de híbridos simples, duplos e triplos, provenientes das mesmas linhagens, estudando a interação genótipo-ambiente para os três tipos de híbridos. Em média, a produção de grãos foi maior para os híbridos simples, triplos e duplos respectivamente. $\mathrm{O}$ autor atribuiu os resultados à maior utilização dos efeitos epistáticos e dominantes nos híbridos simples e triplos em relação aos duplos. Entretanto, salientou que híbridos simples podem apresentar baixa performance dependendo, sobretudo, da combinação específica. Quanto à interação híbrido $\mathrm{x}$ ambiente, houve indicações de que os híbridos simples são mais sensíveis às condições ambientais do que os triplos e duplos; no entanto alguns híbridos simples mostraram-se relativamente estáveis.

A busca de estabilidade de produção nos cultivares tem ganhado importância com o crescimento de cultivo no período de fevereiro a agosto no Brasil. Este cultivo, comumente chamado "safrinha", tem sido realizado, principalmente, nos estados de São Paulo e do Paraná. A escolha do cultivar adequado, com sementes de alta qualidade, diminui o risco característico das culturas de entressafra.

Produtores de milho "safrinha", geralmente, usam medidas tecnológicas de baixo custo, como semeadura de grãos provenientes da segunda geração dos híbridos cultivados na safra normal, além do aproveitamento da adubação residual da cultura anterior. Contudo, tem sido verificado a viabilidade deste cultivo que permite a colheita de uma segunda 
safra no mesmo ano agrícola, proporcionando rentabilidade adicional ao produtor (DURÃES, 1993).

\subsection{Produção de Sementes Híbridas}

A produção de sementes híbridas comerciais de milho é conduzida em campos de cruzamento, a partir de sementes básicas de linhagens, híbridos simples ou híbridos simples modificados dependendo do tipo final de híbrido desejado. Para garantir o cruzamento dos parentais, há a necessidade de controle da polinização, geralmente feito pela remoção do pendão (HUTCHCROFT, 1959; SMITH \& WICK, 1984) ou pela utilização da macho esterilidade genético-citoplasmática no parental feminino, para garantir a polinização pelo parental masculino, $\mathrm{O}$ despendoamento pode ser realizado manualmente, ou em combinação com artifício mecânico, antes da emissão do pólen ou da emergência dos estilo-estigmas do parental feminino.

O despendoamento é uma operação que participa, expressivamente, do custo de produção das sementes híbridas de milho (AIRY, 1950). Assim, durante vários anos, geneticistas e melhoristas desenvolveram o emprego da esterilidade masculina para evitar o despendoamento (JOSEPHSON et al., 1978). A esterilidade citoplasmática, descrita por RHOADES (1933), foi utilizada por ROGERS \& EDWARDSON (1952), para a identificação do citoplasma $T$ (Texas) em milho.

Em virtude do citoplasma $T$ ser suscetível à raça $T$ de Helminthosporium maydis, a sua utilização generalizada na produção de 
híbridos, provocou epidemia de helmintosporiose em 1970 nos EUA e em 1971 no Brasil. A partir desta época, outros citoplasmas passaram a ser investigados e o tipo C (Charrua) foi selecionado por apresentar estabilidade sob variadas condições do ambiente (COCHRAN, 1975; JOSEPHSON et al,, 1978). Plantas da geração $F_{1}$, descendentes de linhagens maternas portadoras desta esterilidade, são, normalmente estéreis. Entretanto há esterilidade parcial e nula, indicando a existência de genes restauradores da fertilidade Assim, a esterilidade depende da ação de genes do núcleo, com ação dominante, e da natureza do citoplasma (CRAIG, 1977; JOSEPHSON et al,, 1978).

Além destes fatores genéticos, DUVICK (1959), verificou que as condições ambientais de umidade e de temperatura podem provocar variações nas taxas de esterilidade masculina entre 0 e $100 \%$; observou que a alta umidade, do solo ou da atmosfera, aliada às baixas temperaturas durante o período de florescimento, contribuíram para o aumento da restauração da fertilidade. Inversamente, seca e altas temperaturas promoveram a máxima esterilidade.

CRAIG (1977) citou o período de despendoamento como fator crítico na produção de sementes híbridas de milho. Destacou que os pendões devem ser removidos antes da liberação do pólen e da emergência dos estiloestigmas; quando o parental fêmea começa a liberar pólen antes da emergência total das folhas superiores ou quando a emissão dos estilo-estigmas ocorre ao mesmo tempo da liberação do pólen, torna-se mais difícil a supervisão do despendoamento. Condições ambientais podem dificultar o despendoamento: 
ventos fortes ou chuvas pesadas podem derrubar e entrelaçar plantas e altas temperaturas podem afetar a emergência de pendões e estilo-estigmas.

A adoção de padrões de tolerância para o número de pendões expostos do parental fêmea, sejam estes provenientes da restauração da fertilidade ou de falhas no despendoamento, é importante para a manutenção da pureza genética nos campos de produção de sementes de milho. Os padrões adotados no Brasil são os mesmos em vigor nos EUA: quando o parental fêmea apresenta $5 \%$ de espigas com estigmas receptivos, o limite de pendões indesejáveis liberando pólen é de $1 \%$ em cada inspeção ou $2 \%$ em um total de três inspeções realizadas em datas sucessivas (CRAIG, 1977; WRIGHT, 1980; WYCK, 1988) É considerado pendão liberador de pólen o que apresenta $2,5 \mathrm{~cm}$ ou mais, da parte superior com anteras expostas (WRIGHT, 1980).

Algumas empresas produtoras de sementes possuem padrões mais rigorosos mantendo este limite em $0,5 \%$. Outras empresas americanas produtoras de sementes adotam outros padrões no despendoamento, combinando a porcentagem de pendões do parental fêmea liberadores de pólen com a porcentagem de espigas com estigmas receptivos (WRIGHT, 1980). Esses padrões estão apresentados na Tabela 1.

AIRY (1950) trabalhou com vários padrões, superiores aos utilizados atualmente, para porcentagens de pendões expostos e de espigas com estilo-estigmas receptivos; não encontrou diferença na produção dos híbridos, possivelmente, em virtude da baixa taxa de autofecundação decorrente da maior produção de pólen do parental masculino em relação ao feminino. 
Tabela 1. Padrões usados para despendoamento em campos de sementes híbridas de milho para assegurar a pureza genética (WRIGHT, 1980).

\begin{tabular}{cccccc}
\hline \hline $\begin{array}{l}\text { Pendões do parental } \\
\text { fêmea que estão }\end{array}$ & \multicolumn{5}{c}{$\begin{array}{c}\text { Espigas do parental fêmea com } \\
\text { estilo-etigmas receptivos (\%) }\end{array}$} \\
\cline { 2 - 6 } liberando pólen (\%) & $<0,25$ & $0,26-4,0$ & $4,1-10,0$ & $10,1-25,0$ & $>25,0$ \\
\hline $0,00-0,24$ & Azul & Azul & Azul & Azul & Azul \\
0,25 & Azul & Azul & Azul & Azul & Verde \\
$0,26-0,50$ & Azul & Azul & Verde & Verm. & Verm. \\
$0,51-1,00$ & Azul & Verde & Verm. & Verm. & Verm. \\
$>1,0$ & Azul & Verm. & Verm. & Verm. & Verm. \\
\hline \hline
\end{tabular}

Azul- sementes híbridas de campos que terão mínimo de contamínação proveniente do parental fêmea autofecundado.

Verde-sementes híbridas de campos que podem ser misturadas com sementes de campo designados como azul para reduzir a porcentagem de contaminação proveniente do parental fêmea autofecundado.

Vermelho-sementes híbridas desses campos podem ser descartadas ou misturadas com sementes de campos designadas com a azul para reduzir a porcentagem de contaminação proveniente do parental fémea autofecundado.

Vermelho*-as operações de despendoamento são suspensas no campo e as sementes não são colhidas

Fatores envolvidos na dispersão do pólen, em campos de produção de sementes de milho, foram estudados por HUTCHCROFT (1959) sob três taxas parciais de despendoamento. Foram utilizados, como marcadores genéticos, o tipo de endosperma e a cor do pericarpo. Os resultados mostraram que a contaminação proveniente de um pendão isolado foi restrita a uma pequena área; entretanto, a distância alcançada pelo pólen contaminante e a data de emissão dos estilo-estigmas do parental fêmea contribuíram para a taxa de contaminação. $O$ indice de contaminação variou com a safra; na primeira $10 \%$ de plantas do parental fêmea não despendoadas promoveram $20 \%$ de contaminação. Entretanto, na safra posterior, $5 \%$ proporcionaram contaminação superior à $30 \%$.

Além do despendoamento e do uso de macho esterilidade genético-citoplasmática, o isolamento por distância, as barreiras naturais, as bordaduras de progenitores masculinos e as semeaduras em épocas não coincidentes com as dos campos vizinhos, têm sido tecnologias empregadas 
(CRAIG, 1977; RUSSEL \& HALLAUER, 1980; MIRANDA FILHO \& VIEGAS, 1987). AIRY (1950) abordou que a abundância de pólen no momento da emergência dos estilo-estigmas do parental feminino, contribui para aumentar a hibridação desejada.

AIRY (1950), RAYNOR et al. (1972) e SMITH \& WYCK (1984) enfatizaram a necessidade de assegurar a polinização cruzada, e conseqüentemente a pureza genética das sementes, através de despendoamento bem conduzido para que seja evitada a autofecundação que conduz à endogamia e consequente perda do vigor.

Os efeitos quantitativos da contaminação dos lotes de sementes híbridas com sementes do parental fêmea autofecundado, tem sido pouco estudado.

BATISTA (1981) utilizou sementes de milho provenientes de plantas autofecundadas e de polinização livre de duas subpopulações ESALQ VF-1 e observou efeitos de depressão por endogamia de 3,5\% em média, para peso e volume de 100 sementes.

Ensaio, envolvendo quatro híbridos com diferentes porcentagens do parental fêmea não despendoado, foi conduzido por CAPELLARO (1992). Sementes provenientes deste campo, foram semeadas para avaliação da produção de grãos e taxa de plantas acamadas no momento da colheita. O autor observou reduções no rendimento de grãos e elevações na taxa de acamamento à medida em que aumentou o número de plantas não despendoadas no campo de origem. 
Avaliando lotes de sementes híbridas de milho apresentando de 0 a $20 \%$ de sementes provenientes do parental fêmea autofecundado, VAN DER WERF et al. (1989) verificaram que, para cada $1 \%$ de sementes autofecundadas presentes na mistura, ocorreu decréscimo de $40-45 \mathrm{~kg} / \mathrm{ha}$ na produção de matéria verde.

PINTÉR (1984), trabalhando com híbridos simples, simples modificado e duplo, estudou o decréscimo, na produção de grãos, de lotes de sementes híbridas contendo $0,5,10,20$ e $30 \%$ de mistura com sementes provenientes do parental fêmea autofecundado. A redução no rendimento de grãos dos lotes, contendo misturas, foi maior nos híbridos simples e simples modificado do que no híbrido duplo. Resultados indicaram que o decréscimo no rendimento, decorrente da mistura, pode ser atenuado com o aumento da densidade de semeadura, Considerando os três híbridos estudados, lotes de sementes híbridas com $10 \%$ de mistura promoveram redução de $8 \%$ no rendimento médio de grãos. A análise de regressão, entre rendimento de grãos e porcentagem de sementes provenientes de autofecundação, não seguiu modelo exponencial, indicando que o efeito de uma unidade de contaminação sobre o rendimento de grãos foi mais pronunciado em baixas porcentagens de contaminação. Assim, o autor concluiu que a redução no rendimento de grãos depende do desempenho das plantas provenientes de autofecundação, e da capacidade de compensação das plantas híbridas.

Resultados encontrados por Frey, citado por PINTÉR (1984) e LOWENBERG (1986), indicaram redução do rendimento de grãos à medida em 
que foi aumentada a porcentagem de sementes provenientes de plantas do parental fêmea autofecundado, em híbridos simples. Quanto aos resultados encontrados por LOWENBERG (1986), para cada $1 \%$ de mistura nas sementes híbridas houve redução de $41 \mathrm{~kg} / \mathrm{ha}$ de grãos correspondente a, aproximadamente, $1 \%$ do rendimento.

Padrões de tolerância, para a presença de sementes provenientes do parental fêmea autofecundado, não têm sido estabelecidos pelos sistemas de produção de sementes. Contudo, empresas estrangeiras adotam, em híbridos simples, limite de $6 \%$ para a presença de sementes provenientes de plantas autofecundadas muito embora, quando semeados, os lotes possam provocar variações desinteressantes na maturidade, cor do grão e altura das plantas (WYCK, 1988).

\subsection{Pureza Genética}

A demanda por sementes híbridas de milho, com alta qualidade, tem aumentado significativamente nas últimas décadas devido ao aprimoramento tecnológico dos agricultores. Conseqüentemente, empresas produtoras de sementes têm investido no controle da qualidade, monitorando todas as fases da produção, objetivando assegurar a chegada ao agricultor da heterose alcançada pelo melhoramento genético, o que atesta a importância da manutenção da pureza genética, de cada combinação híbrida, em todas as fases do processo de produção (CRAIG, 1977; STUBER et al., 1988). 
Em campos de produção de sementes híbridas de milho, a remoção incompleta dos pendões liberadores de pólen do parental fêmea proporciona a ocorrência de autofecundação, principal causa de contaminação genética (HUTCHCROFT, 1959).

A mistura de sementes provenientes do parental fêmea autofecundado, com as sementes híbridas, reduz a qualidade do lote e promove perdas no rendimento contrárias aos objetivos do ganho genético alcançado pelos melhoristas (SMITH \& WYCK, 1984).

Padrões de tolerância, para impurezas genéticas não têm sido estabelecidos pelos sistemas de produção de sementes de milho. Talvez, um dos motivos, para esta situação, seja a falta de metodologias para identificação destas impurezas, principalmente no que se refere à existência de testes aplicáveis na rotina da análise de sementes.

As regras para análise de pureza da Association of Official Seed Analysts (AOSA, 1983) indicam que, diante da impossibilidade de identificação do cultivar através de características das sementes, devem ser consideradas características das plântulas ou das plantas em crescimento.

A expressão de xênia, descrita por JOHNSON \& MILLER (1939) em sementes de milho, pode ser utilizada na estimativa da pureza genética. Exemplo disso, é a mistura de sementes de endosperma duro e amarelo, com as de endosperma branco, mole e alta amilase; além das variações fenotípicas entre ambas, as de endosperma branco diferenciam-se, geneticamente, por apresentarem alelos homozigotos recessivos em um ou mais 
locos. Assim, contaminações resultantes de pólen estranho poderão ser identificadas nas sementes sem a necessidade de avaliação das características das plântulas. Quando ocorre xênia, alguns procedimentos poderão ser tomados para remoção das sementes contaminantes. O mais adequado seria a seleção visual anteriormente à secagem das espigas. Equipamentos eletrônicos, que separam pela cor, podem também, ser usados nesta finalidade, apesar de suas limitações de rendimento (WYCK, 1988).

Uma outra técnica utilizada para determinação da pureza genética, em sementes de milho, foi descrita por JUGENHEIMER (1958). Sementes de endosperma mole, provenientes de plantas do parental fêmea autofecundado foram separadas das sementes híbridas com endosperma duro, através de solução de iodo aplicada em endospermas expostos; os endospermas das sementes, provenientes de autofecundação, mostraram-se com coloração marrom avermelhada, enquanto os das sementes híbridas apresentaram-se com coloração azulada escura.

Testes eletroforéticos, baseados em caracteres bioquímicos, podem ser utilizados para diagnosticar cruzamentos e autofecundações (STUBER et al., 1988, MCDONALD, 1990), na căracterização de híbridos (KORANYI, 1989) e linhagens de milho (EDNIE et al,, 1978, GOODMAN \& STUBER, 1980). Estes testes são embasados em análises de polipeptídios, que representam o produto final de uma função gênica específica (CARRARO, 1990); o autor descreve que, nas técnicas de eletroforese, moléculas são separadas em solução onde é aplicada uma diferença de potencial elétrico. 
Dentre as técnicas utilizadas a SDS-PAGE é a que permite melhor resolução de bandas onde as proteínas perdendo o efeito de carga específica, separam-se devido às diferenças de peso molecular. A avaliação pode ser qualitativa (ausência ou presença) ou quantitativa (concentração dos polipeptídios).

As proteínas de reserva têm sido utilizadas, na eletroforese para estimar a pureza genética, uma vez que sofrem pouca influência dos fatores ambientais (GUPTA \& ROBBELEN, 1986). Entretanto, CHEN \& CHEN (1989) citam que o conteúdo protéico, em endospermas, parece ser controlado por vários genes estruturais em dosagens variáveis, segundo o cruzamento, devido à origem triplóide das células endospermáticas.

Perfis eletroforéticos de zeinas, a maior proteína de reserva em semente de milho, têm sido utilizados na caracterização de linhagens e híbridos (NUCCA et al., 1978; BRINK et al., 1989; OTTOBONI \& STEFFENSEN, 1989). Outros autores têm empregado o perfil eletroforético de proteínas do embrião de milho (DAMEVAL et al., 1987).

O perfil isoenzimático deve refletir a composição genética do cultivar. O número de isoenzimas e locos de zeinas possíveis de análise, através de perfis eletroforéticos, é muito reduzido quando comparado com o número de genes estimados no genoma de milho, apesar destas marcas genéticas estarem situadas em 17 dos 20 braços cromossômicos (SMITH \& SMITH, 1987). Assim, dependendo das linhagens envolvidas, os resultados poderão apresentar variadas correlações com os dados agronômicos. Entretanto, a 
eletroforese, de proteínas desnaturadas, avalia um número maior de polipeptídios (DAMEVAL et al., 1987).

O perfil eletroforético é influenciado pelo órgão vegetal e estádio de desenvolvimento. CARRARO (1990) encontrou maiores diferenças entre perfis eletroforéticos de órgãos do mesmo genótipo do que nos de genótipos diferentes, ainda que fossem fíxados o orgão e o estádio de desenvolvimento.

Apesar da divulgação dos testes eletroforéticos, para avaliação da pureza genética em milho, o seu uso demanda custos apreciáveis, representatividade das amostras e perfeito conhecimento das isoenzimas dos parentais do híbrido (SMITH \& WEISSINGER, 1984). Outras limitações destes testes, envolvendo o comportamento de isoenzimas em locos específicos, são abordadas por SMITH \& WEISSINGER (1984) e STUBER et al. (1988).

Alguns trabalhos têm enfatizado a utilização de características morfológicas das plantas, em vários estádios de desenvolvimento, para a avaliação da pureza genética em milho. Este tipo de avaliação torna-se importante uma vez que, em híbridos duplos a análise isoenzimática pode ser imprecisa devido às eventuais segregações presentes na população. Segregações algumas vezes são encontradas também em híbridos simples, dificultando a interpretação da análise isoenzimática (CARDY \& KANNENBERG, 1982).

A necessidade de serem feitas observações conjuntas na análise isoenzimática e nas características morfológicas no campo, para avaliação da 
pureza genética em milho, foi verificada por ORMAN et al. (1991), apesar de, isoladamente, as informações obtidas pela análise isoenzimática terem sido mais : precisas.

A avaliação da pureza genética, realizada em híbridos de milho através de características morfológicas, foi abordada por PAUKSENS (1960, 1975, 1978) e PAUKSENS \& DHESI (1978). Os autores citam as cores da base do mesocótilo e das raízes, a altura da planta, a ocorrência de perfilho, a data de emissão dos estilo-estígmas, a cor da antera e partes do pendão, a cor do estilo-estígma, o grau de macho esterilidade, as características da palha da espiga, as características dos grãos e espigas na maturidade, como características a serem consideradas. A coloração de um anel facilmente visualizado, envolvendo a base de cada uma das flores do pendão, parece ser um bom marcador em milho; este anel ocorre no ponto de conexão das glumas, podendo apresentar-se com colorações avermelhada, esverdeada, púrpura ou marrom. Entretanto, as características morfológicas podem apresentar imprecisão devido à interação com o ambiente e à falta de conhecimento do controle genético envolvido (DITMER, 1979; SCHMIDT, 1979; SMITH \& SMITH, 1989).

Por outro lado, problemas associados à interpretação de descritores morfológicos podem ser contornados com avaliações fenotípicas em condições ambientais distintas ou com a seleção de descritores de reduzida interação com o ambiente (GOODMAN \& PATERNIANI, 1969). 
SMITH \& SMITH (1989) estudaram o grau de interação ambiental, de 57 características morfológicas em 31 linhagens de milho, através de estimativas de repetibilidade de dados coletados em três locais durante dois anos. A estimativa de repetibilidade foi maior nos dados dos três locais em dois anos do que nos dados de três locais em um ano. No entanto, para a avaliação da pureza genética, a segunda situação mostrou-se mais interessante por permitir repetibilidade para características da espiga e pendão (cor do estiloestigma, número de ramificações no pendão primário, cor da antera e cor do grão) e para algumas características vegetativas (ângulo da folha e número de folhas).

As características morfológicas, utilizadas como descritores de híbridos de milho, estão sugeitas, ainda, à variabilidade na população, proveniente da diferença genética entre as linhas parentais e da geração de seleção (SMITH \& SMITH, 1987).

Variações na pigmentação de antocianina, em várias partes das planta, têm dificultado a identificação de cultivares de milho (SINGH \& SARKAR, 1982; SRIVASTAVA \& AGRAWAL, 1985; STYLES, 1993). Os autores enfatizaram que o entendimento da genética da pigmentação de antocianina, em milho, é dificultada pela presença e por interações de vários genes antocianínicos. Dezessete locos estão envolvidos na elaboração e distribuição do pigmento em vários tecidos de plantas e sementes; destes, nove são responsáveis pela expressão do pigmento na planta. Contudo, o alelo B parece ser o mais importante na determinação da presença da pigmentação. 
Entretanto, para a formação de pigmentação púrpura em todos os tecidos da planta, há a necessidade da ação complementar de sete genes, um deles passível de substituição pela luz solar. Quando o alelo recessivo b está presente, partes da planta não apresentam pigmentação púrpura ou marrom, apesar da presença de alguns pigmentos em tecidos de plantas ser condicionada pela epistase de alelos R sobre o alelo B.

Antocianinas são pigmentos flavonóides, sintetizados em tecidos de coleoptilo, raiz primária, lígula, margem de folhas, estilo-estigma, gluma, antera, pericarpo, escutelo, embrião, colmo, palha da espiga e outros. Análises genéticas têm identificado vários genes requeridos para a síntese de pigmentos antocianínicos. Entre estes, quatro alelos reguladores (R, B, C1 e PL) codificam proteínas necessárias para a transcrição de um grupo de genes estrutural, codificando a biossíntese de enzimas para formação de antocianina (COCCIOLONE \& CONE, 1993)

SINGH \& SARKAR (1982) apresentaram as constituições genotípicas requeridas para produção de antocianina em várias partes da planta. Em resumo, o alelo B é requerido para pigmentação de antocianina em todas as partes da planta, com exceção da coloração da antera e estilo-estígma. Contudo, o alelo $\mathrm{R}$ pode substituir o alelo $\mathrm{B}$ e da mesma maneira este último pode ser substituído pelo alelo LC em certas partes da planta (SINGH \& SARKAR, 1982, STYLES, 1993). O primeiro autor citou ainda que o alelo R1scm regula a síntese de antocianina no coleóptilo, mas apresenta pouca expressão no embrião e pericarpo. Alguns alelos como PL podem induzir a 
síntese e distribuição de antocianina sob baixa intensidade luminosa, enquanto outro alelo como pl iniciam suas atividades somente quando os tecidos são expostos a uma alta intensidade luminosa.

Quando o alelo B está envolvido na formação de antocianina, a avaliação e seleção de genótipos, através de características fenotípicas baseadas neste pigmento, têm sido viáveis (SRIVASTAVA \& AGRAWAL, 1985).

Trabalho conduzido por PAYNE (1986) mostrou que vários laboratórios filiados à AOSA utilizam características morfológicas de sementes e de plantas para a identificação varietal em algumas espécies. No caso específico do milho, $50 \%$ utilizam características morfológicas de plantas em vários estádios de desenvolvimento e os demais utilizam eletroforese de isoenzimas. $\mathrm{O}$ autor citou, como desvantagens da utilização de eletroforese, $\mathrm{O}$ alto custo do equipamento necessário, a necessidade de treinamento dos analistas e a baixa produtividade da análise. Entretanto, o tempo requerido é maior nas avaliações que consideram características morfológicas, que, adicionalmente, demandam o uso de maior espaço físico para a sua utilização.

Comparações entre as técnicas de eletroforese e de características morfológicas foram realizadas por SMITH \& WYCK (1984), com o objetivo de estimar a porcentagem de sementes provenientes do parental fêmea autofecundado em lotes de sementes híbridas de milho. As avaliações realizadas em campo, utilizando características morfológicas de plantas, foram efetuadas nos estádios de 5-7 folhas definitivas, na antese e na maturidade. 
Para a condução dos testes eletroforéticos utilizaram-se tecidos de coleoptilo de plântulas com cinco dias. Os resultados dos testes eletroforéticos foram mais exatos; os obtidos a partir de características morfológicas, nos estádios de planta com 5-7 folhas definitivas e na antese foram inconsistentes, enquanto os obtidos na maturidade, apresentaram-se com precisão intermediária.

\subsection{Qualidade de Sementes}

A qualidade da semente é fator a ser considerado em qualquer programa de produção agrícola, visto que as características agronômicas, dos cultivares obtidos pela pesquisa, chegam aos agricultores através da semente (BARROS, 1986). Esta pode ser analisada sob aspectos genéticos, físicos, físiológicos e sanitários. A qualidade genética é representada entre outros, por atributos de pureza varietal, homogeneidade, potencial de rendimento, resistência às moléstias e aos insetos, precocidade e qualidade do produto (POPINIGIS, 1975).

Cultivares com características específicas, resultantes de uma determinada combinação gênica, são desenvolvidos pelos melhoristas e requerem a manutenção de suas características para que possam expressar o seu potencial genético e suas qualidades agronômicas. Assim, em campos de produção de sementes híbridas de milho, são estabelecidos os limites máximos de tolerância para agentes de contaminação genética, durante o desenvolvimento da cultura, com o objetivo de manter a qualidade genética do cultivar. Dentre desses agentes, os pendões liberadores de pólen do parental 
fêmea proporcionam potencial de autofecundação e comprometem o ganho esperado com a heterose, podendo, ainda, influenciar a qualidade físiológica das sementes (EAGLES \& HARDACRE, 1978, SMITH \& WYCK, 1984).

A qualidade físiológica da semente compreende todos os atributos que indicam sua capacidade de desempenhar funções vitais, sendo caracterizada pelo poder germinativo, pelo vigor e pela longevidade (POPINIGIS, 1975).

As bases da heterose, ou vigor híbrido, não estão totalmente elucidadas. No entanto, o envolvimento de hormônios, como as auxinas (TAFURI, 1966) e giberelinas (ROOD et al., 1983 e 1990), na manifestação da heterose, parece evidente. Resultados de pesquisa têm indicado que o controle da síntese de $\alpha$-amilase, e subseqüente hidrólise das reservas de sementes, apresenta uma ligação entre as giberelinas e a heterose em milho (PALEG, 1965).

Resultados obtidos por ROOD et al. (1983 e 1990) sugerem que as linhagens de milho são menos vigorosas que seus híbridos descendentes em parte, em função da deficiência de giberelinas; houve uma correlação positiva entre o nível de giberelinas, encontrado nas plântulas, e os aumentos da taxa de crescimento, da área foliar e da altura de plantas de milho. O autor cita, ainda, a deficiência de giberelinas como uma das causas da depressão endogâmica.

Uma outra explicação para o maior vigor, observado em plântulas híbridas de milho, é a maior eficiência do sistema enzimático envolvido no processo de germinação. Entretanto, em alguns trabalhos, isto 
não tem sido verificado. HAGEMAN et al. (1967) não observou diferenças na atividade das enzimas triosefosfato, desidrogenase, aldolase e glicose-6-fosfato desidrogenase entre plântulas provenientes de sementes híbridas e de suas linhagens parentais.

BERNSTEIN (1943) estudou a mobilização de reservas do endosperma de sementes híbridas de milho, e de suas respectivas linhagens, durante o processo de germinação. Foi observada digestão mais rápida do amido, seguida pelo acúmulo de açúcares redutores no endosperma, nas sementes híbridas em relação as sementes das linhagens, proporcionando crescimento mais rápido nas plântulas híbridas.

Resultados obtidos, no trabalho desenvolvido por MARYAM \& JONES (1983), indicaram superioridade da qualidade fisiológica de sementes híbridas de milho, em relação às sementes de suas linhagens parentais, quanto ao número de sementes germinadas e à velocidade de emergência. Nesta mesma linha, PESEY (1970) estudou a tolerância ao frio de híbridos duplos e simples e de suas respectivas linhagens parentais. Maior emergência, sob baixas temperaturas, foi observada nos híbridos duplos, seguidos pelos híbridos simples e pelas linhagens. $O$ autor atribuiu este fato à constituição gênica do embrião e às características do endosperma e do pericarpo das sementes. Outro aspecto abordado, neste trabalho, foi o da existência de efeito maternal, no grau de tolerância às baixas temperaturas, sobre a germinação e velocidade de emergência nas plântulas híbridas; assim, plântulas descendentes de fêmeas com baixa tolerância a o frio, também apresentaram esta característica. O efeito 
materno na porcentagem de germinação, sob baixas temperaturas, também foi constatado por EAGLES \& HARDACRE (1978), ao observar depressão por endogamia, na velocidade de emergência.

Em programas de melhoramento de milho, 0 teste de frio tem se mostrado eficiente para a seleção de linhagens e híbridos tolerantes às condições de baixa temperatura (MARYAM \& JONES, 1983; HOPE et al., 1992). SCHELL et al. (1991) relatou que os híbridos podem apresentar comportamento diferente quanto à tolerância ao frio devido, principalmente, às diferenças no nível de ATP no embrião. O teste de frio, também, tem sido amplamente utilizado para avaliar o vigor de sementes de milho (TATUM \& ZUBER, 1943; RINKE, 1953; HOPPE, 1956; FRATIN, 1987).

Inicialmente o objetivo deste teste foi o de procurar simular condições desfavoráveis presentes na época de semeadura (excesso de umidade no solo e baixas temperaturas) nos Estados Unidos. Atualmente, este teste é empregado tanto para prever o desempenho das sementes no campo como no armazenamento, além de ser utilizado para avaliar o efeitos de tratamentos fungicidas nas sementes (MARCOS FILHO et al., 1987).

Embora empregado para avaliar o desempenho de sementes no campo, em condições de alta umidade do solo e baixa temperatura, o teste de frio pode apresentar baixa correlação com a emergência de plântulas nestas condições (BURRIS \& NAVRATIL, 1979); os autores atribuíram ao substrato a principal causa de imprecisão do teste. 
No teste de frio, a combinação de baixa temperatura com alta umidade é utilizada para permitir apenas a sobrevivência das sementes vigorosas, uma vez que as condições utilizadas podem reduzir a velocidade de germinação e favorecer o desenvolvimento de microrganismos prejudiciais (MARCOS FILHO et al., 1987).

Ênfase tem sido dada, também, à utilização do teste de envelhecimento artificial, para avaliação do vigor de sementes, por ser de fácil condução e aplicável em várias espécies, além de produzir informações consistentes (MCDONALD, 1977; LIN \& PEARCE, 1990; ODIEMAH, 1991). O princípio básico deste teste é o de que o processo de deterioração, nas condições do teste, é similar ao que ocorre em condições normais de armazenamento, porém com velocidade de deterioração aumentada. 0 potencial de armazenamento de 31 lotes de sementes de milho, determinado através do teste de envelhecimento artificial, mostrou uma correlação entre a germinação, após o envelhecimento artificial, e a viabilidade das sementes durante 0 armazenamento (DELOUCHE \& BASKIN, 1973).

Trabalho, desenvolvido por ODIEMAH (1991), mostrou resposta diferencial de dez híbridos de milho, quanto ao vigor, com o emprego do teste de envelhecimento artificial. Neste trabalho, híbridos com sementes de maior qualidade, foram os mais produtivos. $\mathrm{O}$ autor explica que a diferença na qualidade de sementes entre os híbridos foi devida, em parte, à variação genotípica. 
Sementes de um híbrido simples e um híbrido duplo de milho, apresentando duas linhagens parentais comuns, foram submetidas ao teste de envelhecimento artificial e ao teste padrão de germinação. Sementes do híbrido duplo apresentaram maior porcentagem de germinação em ambos os testes. A diferença em favor do híbrido duplo foi mais acentuada no teste de envelhecimento artificial. Neste trabalho, os autores estudaram a deterioração da membrana e mudanças bioquímicas ocorridas durante o processo de envelhecimento das sementes. Dentre outras mudanças, houve redução no material de reserva, como carboidratos e proteínas, e decréscimo na atividade de enzimas como a fosfatase ácida e a desidrogenase. Além disso, foram constatados aumentos no total de aminoácidos livres e na atividade de amilase e protease, confirmando a degradação de substâncias de reserva durante o envelhecimento (BASAVARAJAPPA et al., 1991).

Embora o envelhecimento artificial apresente características desejadas para um teste de vigor, é freqüente a falta de repetibilidade dos resultados dentro e entre laboratórios (KRZYZANOWSKI \& FRANÇA NETO, 1991). Um dos fatores que contribui para esta variação é o teor de água inicial da semente, que por sua vez, influencia o grau de deterioração durante o teste (MCDONALD, 1977).

A utilização do teste de condutividade elétrica, para a avaliação do vigor de sementes de várias espécies, tem aumentado nas últimas décadas (TEKRONY, 1983), inclusive na avaliação de sementes de milho (GILL \& DELOUCHE, 1973; CÍCERO, 1987; HERTER \& BURRIS, 1989, BRUGGINK 
et al, 1991). Neste teste, a qualidade das sementes é avaliada, mediante a leitura da condutividade elétrica, na solução de embebição de sementes. $\mathrm{O}$ valor da condutividade, função da quantidade de lixiviados na solução, está diretamente relacionado com a integridade das membranas celulares (VIEIRA, 1994). Assim, as sementes mais deterioradas liberam maiores quantidades de exsudatos, incluindo açúcares, ácidos orgânicos, aminoácidos, proteínas, substâncias inorgânicas e íons (MARCOS FILHO et al., 1987).

O teste padrão de germinação, também, é utilizado para a avaliação da qualidade físiológica das sementes de milho. No entanto, não oferece indicação segura do desempenho das sementes, nas condições de campo, por propiciar condições ótimas às sementes e, com isso permitir que sementes com avançado grau de deterioração originem plântulas consideradas como "normais" (TEKRONY \& EGLI, 1977; POPINIGIS, 1985). O dois primeiros autores destacaram que as transformações degenerativas, ocorridas durante o processo de deterioração e não adequadamente avaliadas pelo teste de germinação, podem exercer influência na capacidade de emergência, no crescimento e no rendimento das plantas resultantes. Essas transformações podem ser avaliadas pelos testes de vigor, que detectam pequenas diferenças entre os estádios de deterioração de lotes de sementes.

Avaliações, da deterioração das sementes, têm sido realizadas através de testes físiológicos (porcentagem e velocidade de germinação e emergência) e da observação de alterações bioquímicas ou metabólicas (respiração, atividade enzimática, variações nas substâncias de reserva e 
organização do sistema de membranas) (McDONALD Jr., 1980; BEWLEY \& BLACK, 1985). Sabe-se que a deterioração manifesta-se de diferentes formas, razão pela qual vários testes de vigor têm sido propostos, uma vez que um teste não consegue avaliar, isoladamente, todos os fatores que podem afetar o estabelecimento das plântulas no campo. 


\section{MATERIAL E MÉTODOS}

O presente trabalho foi conduzido no laboratório de análise de sementes e na área experimental do Departamento de Agricultura da Escola Superior de Agricultura "Luiz de Queiroz" (ESALQ) da Universidade de São Paulo, em Piracicaba SP, e nas áreas experimentais da Cargill Agrícola S/A em Santa Helena de Goiás GO, Paranapanema SP, Guaíra SP e Ituverava SP.

\subsection{Produção de Sementes}

Inicialmente, foram instalados campos de produção de sementes na estação experimental da Cargill Agrícola S/A em Santa Helena de Goiás GO, em julho de 1992, para obtenção de sementes dos híbridos C 701, C 425, C 808 A e C 901. As características destes híbridos estão apresentadas na Tabela 2.

Tabela 2. Descrição dos híbridos utilizados no trabalho.

\begin{tabular}{llcll}
\hline \hline Híbrido & Típo e Ciclo & Soma Térmica* & Grão e Cor & Porte \\
\hline C 701 & duplo/precoce & 860 & semi duro/alaranjado & médio/alto \\
C 425 & duplo/precoce & 900 & semi duro/alaranjado & médio/alto \\
C 808 A & triplo/super precoce & 810 & semi duro/alaranjado & médio/baixo \\
C 901 & simples/super precoce & 790 & semi dentado/amarelo & baixo \\
\hline \hline
\end{tabular}

* plantio até florescimento

Concomitantemente à produção das sementes híbridas, foram produzidas sementes do parental fêmea autofecundado de cada híbrido. Para a 
obtenção das sementes híbridas, foram instaladas 15 linhas de $5 \mathrm{~m}$ de comprimento de cada parental. Para garantir o cruzamento entre os parentais, foram realizados o despendoamento nas linhas do parental fềmea e a proteção de suas espigas com saco plástico. Quando os estilo-estígmas encontravam-se receptivos, procedeu-se ao cruzamento, manualmente, com pólen do parental masculino coletado de várias plantas e homogeneizado.

Sementes, provenientes do parental fêmea autofecundado, foram obtidas em 15 linhas de $5 \mathrm{~m}$ de comprimento. As espigas foram protegidas e a autofecundação realizada quando os estilo-estígmas encontravam-se receptivos.

Durante o processo de produção das sementes, foram realizados os tratos culturais recomendados à cultura. A adubação na semeadura, foi realizada de acordo com análise do solo, na dosagem de $350 \mathrm{~kg} / \mathrm{ha}$ da fórmula 5:25:25. Após trinta dias da semeadura, foi realizada adubação em cobertura na dosagem de 90 kg de nitrogênio/ha.

Em novembro de 1992, procedeu-se à colheita manual das espigas que, na ocasião apresentavam sementes com grau de umidade em torno de $25 \%$. A secagem, foi realizada em secador de espigas e seguida pela debulha manual.

A classificação das sementes, pela largura, foi realizada em peneiras manuais; foram utilizadas, apenas, as sementes retidas na peneira com crivos de diâmetro com $22 / 64$ de polegada. Após a classificação, as sementes foram tratadas com inseticidas (deltametrina $2,5 \%, 1 \mathrm{ppm}$ e pirimiphos-metil $50 \%, 4 \mathrm{ppm}$ ) e fungicida (captan $75 \%, 1200 \mathrm{ppm}$ ). 
A identificação das sementes híbridas e das sementes provenientes do parental fêmea autofecundado, foi efetuada com corantes distintos durante o tratamento sanitário para facilitar a instalação dos ensaios subseqüentes.

Sementes do parental fêmea autofecundado foram misturadas às sementes híbridas nas taxas de: $0,5,10,20$ e $100 \%$ constituindo novos lotes. Assim, avaliou-se o efeito das misturas na qualidade físiológica dos lotes e em componentes da produção.

\subsection{Avaliação da Qualidade Fisiológica}

Para a avaliação da qualidade físiológica dos lotes, foram conduzidos testes de germinação, envelhecimento artificial, frio, condutividade elétrica e emergência em campo.

\subsubsection{Teste de Germinação}

O teste de germinação, realizado com duas sub-amostras de 50 sementes para cada repetição, foi instalado em papel toalha, marca Germitest, na forma de rolo, umedecido com água na quantidade equivalente a 2,5 vezes o peso do substrato seco. A seguir as sementes foram colocadas para germinar em aparelho regulado à temperatura constante de $30^{\circ} \mathrm{C}$. As avaliações foram feitas aos quatro e sete dias após a semeadura, segundo as prescrições contidas nas Regras para Análise de Sementes (BRASIL, 1980). 


\subsubsection{Envelhecimento Artificial}

Duas sub-amostras de 50 sementes, para cada repetição foram acondicionadas em mini-câmaras individuais, tipo gerbox com tela. No fundo da mini-câmara foram adicionadas $40 \mathrm{ml}$ de água destilada e, em seguida, foram mantidas em temperatura de $42^{\circ} \mathrm{C}$ por 96 horas, conforme metodologia proposta pela AOSA (1983) e descrita por MARCOS FILHO et al. (1987) e MARCOS FILHO (1994).

Após o período de envelhecimento, as sementes foram colocadas para germinar, segundo a metodologia descrita no item 3.2.1, com contagem das plântulas normais após 4 dias de permanência no germinador.

\subsubsection{Teste de Frio}

O teste de frio foi conduzido em caixa plástica utilizando, como substrato, mistura de areia e solo proveniente de área cultivada com milho, durante vários anos, na proporção de $2: 1$ em peso, respectivamente. A umidade do substrato foi ajustada para $60 \%$ da capacidade de retenção.

Utilizaram-se 400 sementes, por tratamento, distribuidas em quatro repetições de 100 sementes. Após a semeadura, as sementes foram cobertas com uma camada de $3 \mathrm{~cm}$ do substrato e as caixas foram protegidas da desidratação e dispostas, ao acaso, em câmara regulada a $10^{\circ} \mathrm{C}$ por sete dias (MARCOS FILHO et al., 1987). Após esse período, as caixas foram mantidas, sob condições de ambiente no laboratório, para a contagem das plântulas emersas no sétimo dia. 


\subsubsection{Teste de Condutividade Elétrica}

O teste de condutividade elétrica foi conduzido segundo metodologia descrita por MARCOS FILHO et al. (1987) e VIEIRA (1994). Quatro repetições de 25 sementes, para cada tratamento, previamente escolhidas, para remoção das que se apresentavam visualmente danificadas, foram pesadas em balança analítica e colocadas em copos plásticos, contendo $75 \mathrm{ml}$ de água destilada, e mantidas à temperatura de $25^{\circ} \mathrm{C}$ por 24 horas. No final desse período, a condutividade elétrica da solução foi determinada através de leituras em condutivímetro Digimed CD-20; os valores foram expressos em $\mu \mathrm{mhos} / \mathrm{cm} / \mathrm{g}$ de sementes.

\subsubsection{Emergência em Campo}

Para avaliação da emergência em campo, utilizaram-se quatro repetições de 100 sementes, por tratamento, distribuídas em sulcos com 3 metros de comprimento e $5 \mathrm{~cm}$ de profundidade espaçados de $30 \mathrm{~cm}$. Após 21 dias da semeadura, procedeu-se à contagem do número de plântulas emersas. Durante o período de condução do teste, o solo foi mantido úmido através de irrigação.

\subsubsection{Análise dos Dados}

Os testes realizados para avaliação da qualidade fisiológica seguiram o delineamento experimental inteiramente casualizado em esquema fatorial $(4 \times 5)$ com quatro repetições. Os fatores estudados foram: 
- Híbridos: C 701, C 425, C 808 A e C 901.

- Taxas de contaminação nos lotes: $0,5,10,20$ e $100 \%$.

A transformação dos dados porcentuais não foi necessária uma vez que a diferença, entre a maior e a menor média dos testes, não ultrapassou $20 \%$. Transformações são recomendadas quando a diferença torna-se mais acentuada (BANZATTO \& KRONKA, 1992).

A comparação das médias foi feita pelo teste de Duncan ao nível de $1 \%$ de probabilidade. A análise dos dados foi realizada através do sistema de Análise Estatística - SANEST para micro computadores (ZONTA et al., 1984).

\subsection{Ensaio em Campo}

Os experimentos foram conduzidos nos municípios de Ituverava, Guaíra, Piracicaba e Paranapanema, localizados no Estado de São Paulo. Nos dois primeiros locais, a semeadura foi realizada na época de cultivo denominada "safrinha". Em Piracicaba e Paranapanema a semeadura deu-se em época normal.

Os dados referentes a altitude e latitude desses locais estão apresentados na Tabela 3.

Tabela 3. Locais de semeadura com respectivas altitude e latitude.

\begin{tabular}{lcl}
\hline Local & Altitude & Latitude \\
\hline Ituverava & $605 \mathrm{~m}$ & $20^{\circ} 20^{\prime}$ (sul) \\
Guaíra & $490 \mathrm{~m}$ & $20^{\circ} 18^{\prime}$ (sul) \\
Piracicaba & $545 \mathrm{~m}$ & $22^{\circ} 74^{\prime}$ (sul) \\
Paranapanema & $610 \mathrm{~m}$ & $23^{\circ} 40^{\prime}$ (sul) \\
\hline \hline
\end{tabular}


Antes da instalação dos experimentos, foram retiradas amostras de solo para a avaliação das propriedades químicas, cujos resultados estão apresentados na Tabela 4.

Tabela 4. Resultados de análise química do solo dos diferentes locais.

\begin{tabular}{lrrcc}
\hline \hline & \multicolumn{3}{c}{ Locais } \\
\cline { 2 - 5 } & Ituverava & Guaíra & Piracicaba & Paranapanema \\
\hline $\mathrm{pH}\left(\mathrm{CaCl}_{2}\right)$ & 5,70 & 5,70 & 4,70 & 5,90 \\
Carbono orgânico (\%) & 3,80 & 3,70 & 2,60 & 2,40 \\
$\mathrm{PO}_{4}^{3-}(\mathrm{ppm})$ & 12,00 & 15,00 & 12,00 & 1,00 \\
$\mathrm{~K}^{+}(\mathrm{meq} / 100 \mathrm{ml}$ de terra) & 0,54 & 0,59 & 0,51 & 0,29 \\
$\mathrm{Ca}^{2+}$ (meq/100ml de terra) & 7,80 & 6,90 & 4,00 & 5,50 \\
$\mathrm{Mg}^{2+}($ meq/100ml de terra) & 1,10 & 1,10 & 0,90 & 1,10 \\
$\mathrm{H}^{+}+\mathrm{Al}^{2+}($ meq/100ml de terra) & 1,80 & 1,80 & 5,20 & 1,50 \\
$\mathrm{~V}(\%)$ & 84,00 & 82,70 & 51,00 & 82,10 \\
\hline
\end{tabular}

Nas Figuras 1, 2, 5 e 6 estão apresentados os dados de distribuição de chuvas e nas Figuras 3, 4, 7 e 8 os dados de temperaturas máxima, mínima e média que ocorreram nos locais durante o ciclo da cultura.

As datas de semeadura e colheita dos ensaios, nos diferentes locais, estão representados na Tabela 5.

Tabela 5. Data de semeadura e colheita dos ensaios de campo.

\begin{tabular}{lcc}
\hline Local & Semeadura & Colheita \\
\hline Ituverava & $09 / 03 / 93$ & $10 / 08 / 03$ \\
Guaíra & $10 / 03 / 93$ & $11 / 08 / 93$ \\
Piracicaba & $22 / 12 / 92$ & $30 / 04 / 93$ \\
Paranapanema & $19 / 12 / 92$ & $22 / 04 / 93$ \\
\hline
\end{tabular}



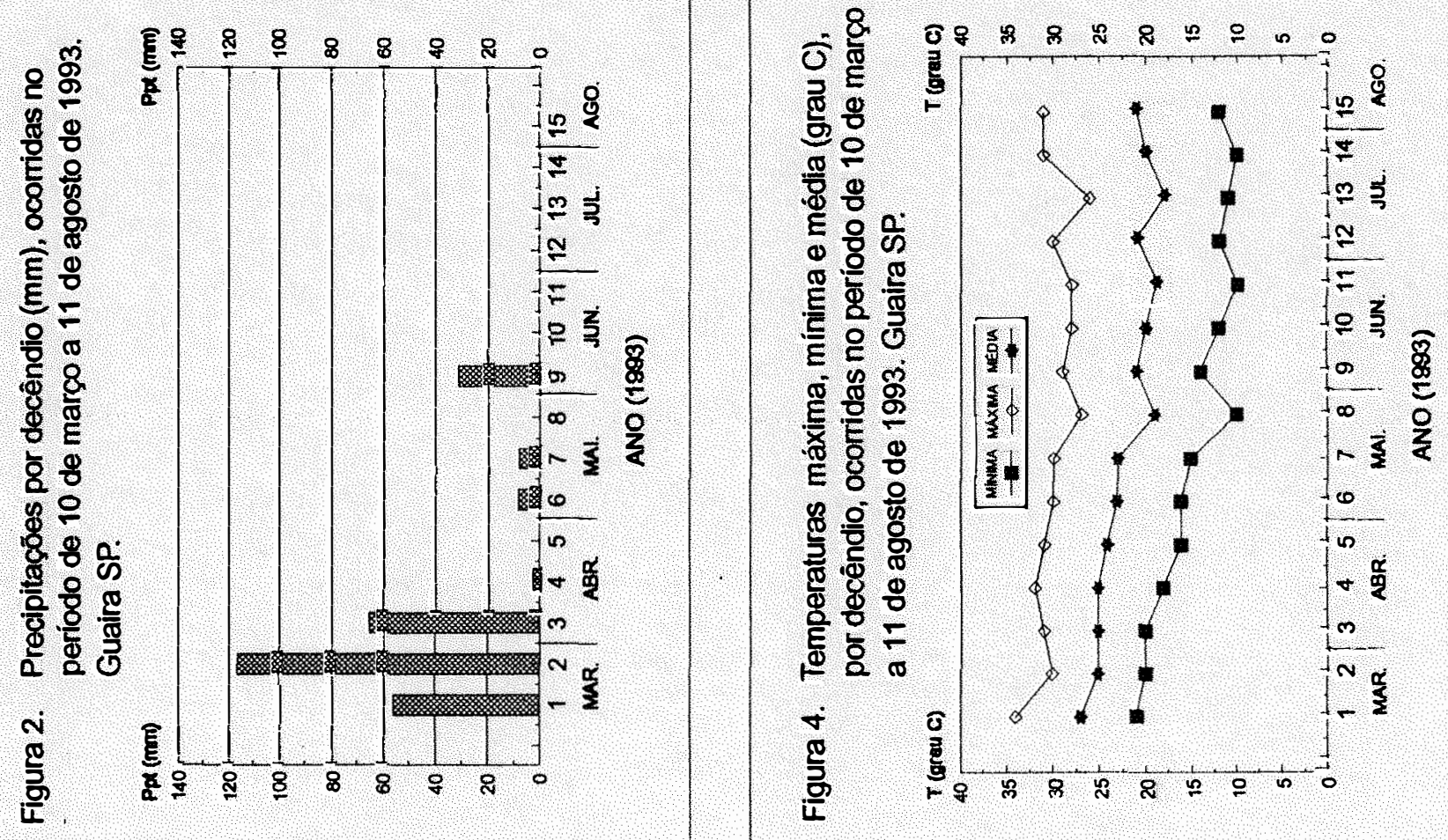

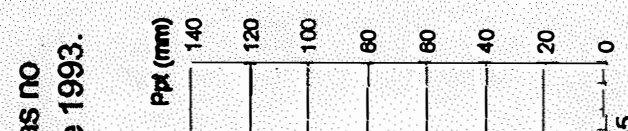

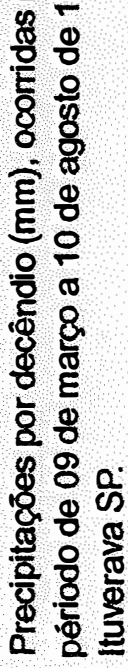

$\frac{12}{7}$

- ई

으

$=$

$-1$

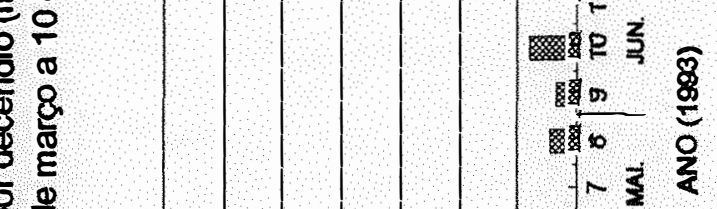

0

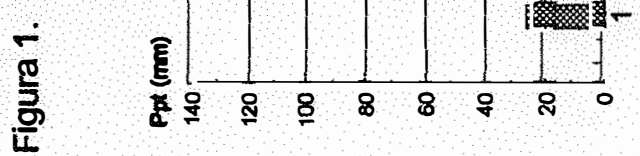

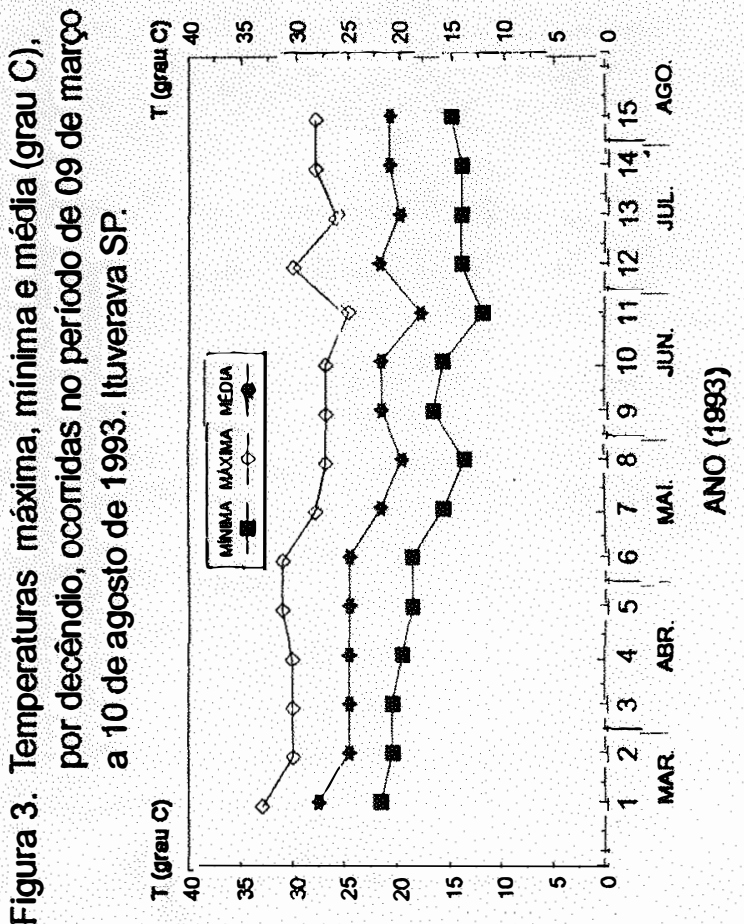



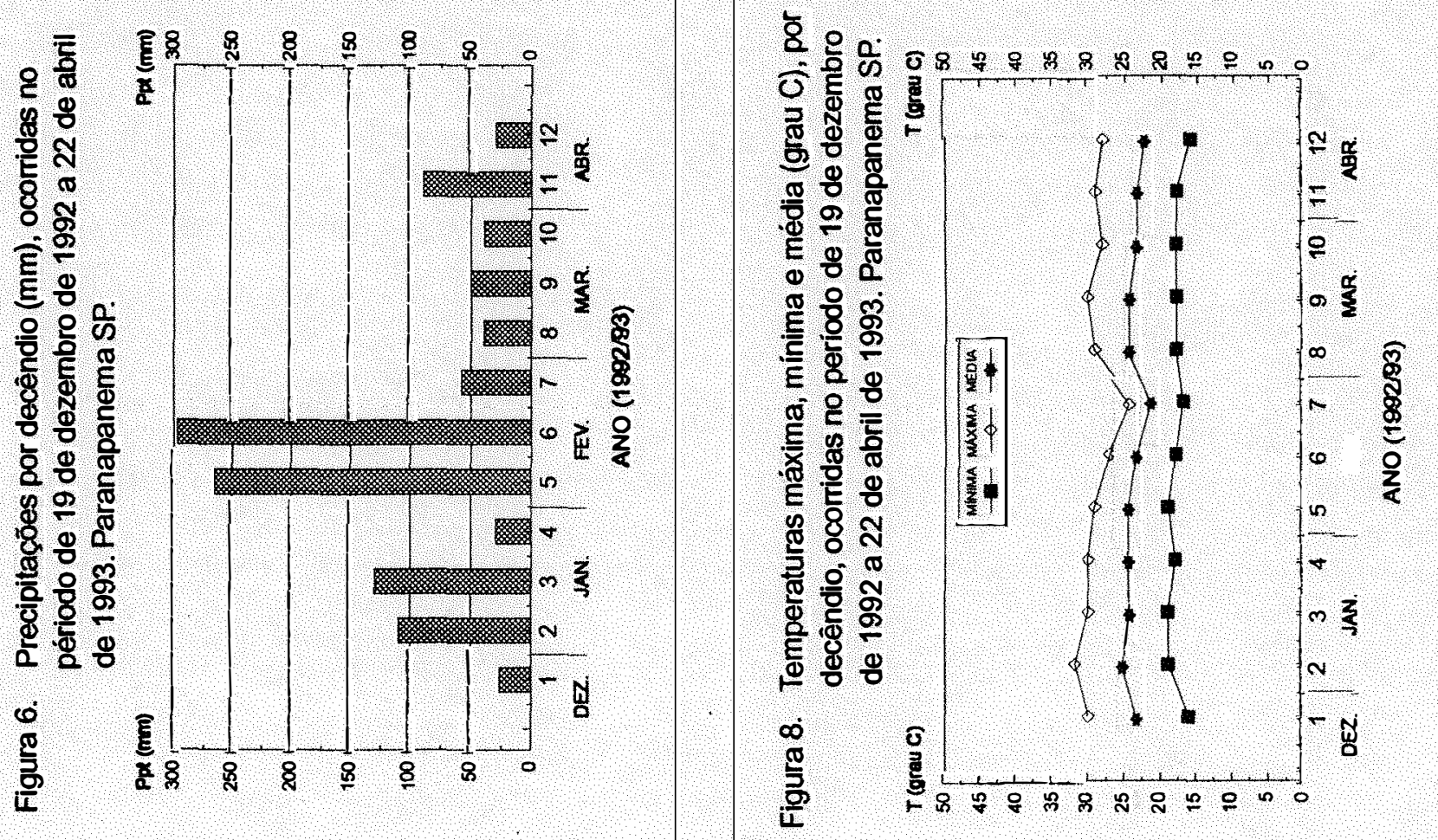

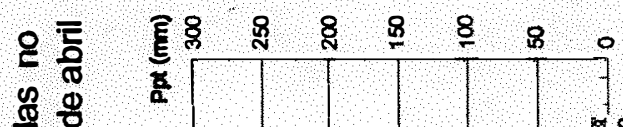
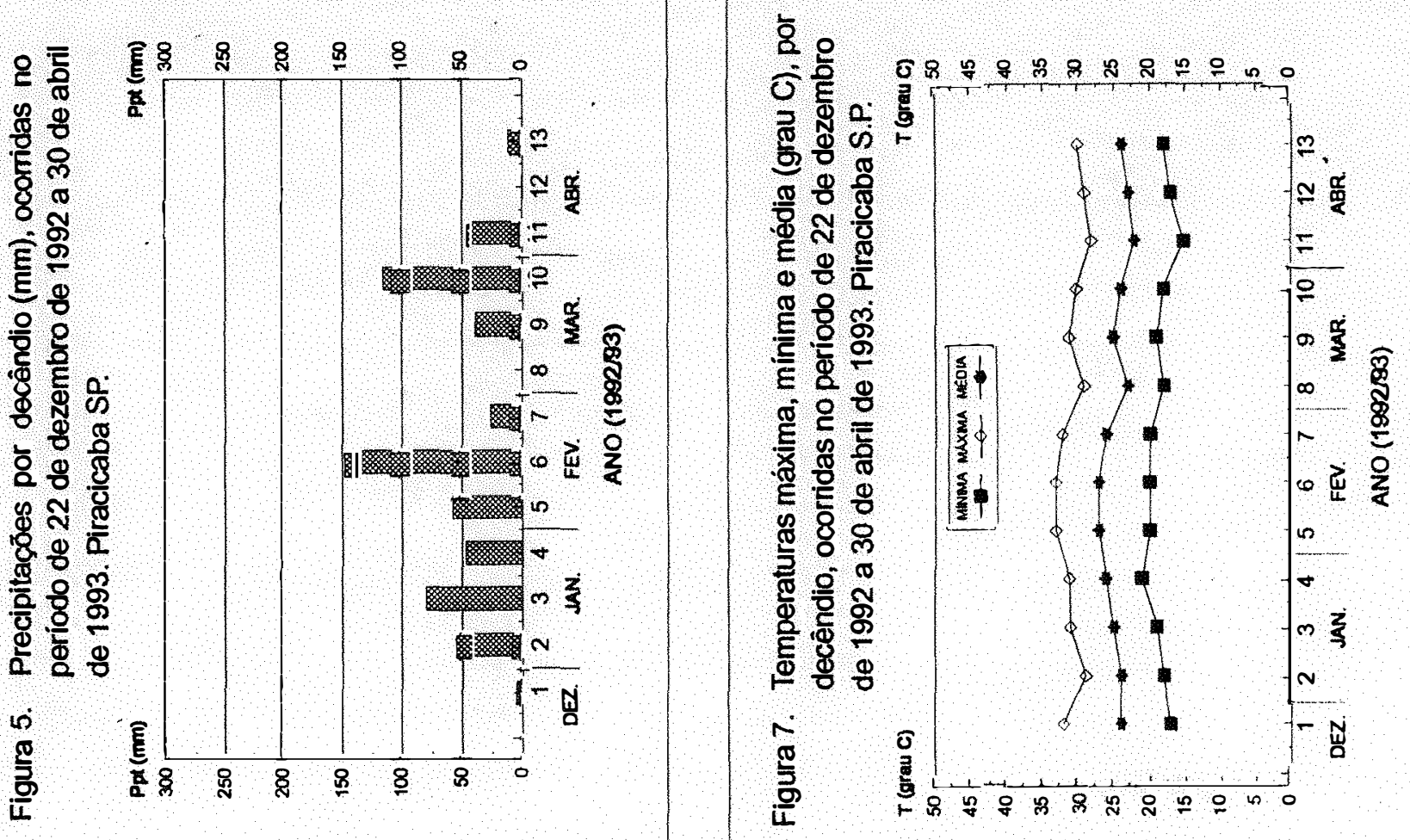
O delineamento experimental utilizado foi o de blocos ao acaso com esquema fatorial $(4 \times 5)$ com seis repetições, tendo-se como fatores:

$$
\begin{aligned}
& \text { - Híbridos: C 701, C 425, C } 808 \text { A e C } 901 \text {. } \\
& \text { _ } \quad \text { Taxas de contaminação nos lotes: } 0,5,10,20 \text { e } 100 \% \text {. }
\end{aligned}
$$

Cada parcela constou de seis linhas de $5 \mathrm{~m}$ de comprimento, espaçadas de $0,90 \mathrm{~m}$ entre si, contendo cinco plantas por metro linear. Para garantir a densidade populacional foram semeadas dez sementes por metro, sendo duas senentes por cova, procedendo-se o desbaste, aos 30 dias após a semeadura. Consideraram-se como úteis apenas as quatro linhas centrais da parcela.

As taxas de contaminação dos lotes dentro das parcelas, foram conseguidas com a marcação, através de estacas de bambu, do local de colocação das sementes provenientes de autofecundação; adicionalmente, um croqui indicava as posições na parcela. Por ocasião do desbaste, as plantas provenientes de autofecundação foram etiquetadas, facilitando as avaliações posteriores.

Nos experimentos em Piracicaba e Paranapanema foi feita uma adubação básica de semeadura, equivalente a $400 \mathrm{~kg} / \mathrm{ha}$ da fórmula comercial 4-2020. Em Guaíra e Ituverava a adubação de semeadura correspondeu à metade da utilizada em Piracicaba e Paranapanema procurando simular a adotada pelos agricultores no cultivo do milho "safrinha".

Em Piracicaba e Paranapanema foram realizadas adubações em cobertura, aos 30 e 45 dias após a semeadura, ambas na dosagem de $45 \mathrm{~kg}$ de nitrogênio/ha na forma de sulfato de amônio. Em Guaíra e Ituverava, a cobertura 
foi feita aos 30 dias após a semeadura com a dosagem de $60 \mathrm{~kg}$ de nitrogênio/ha na forma de sulfato de amônio.

No decorrer do experimento foram empregados os tratos culturais recomendados para a cultura. Paranapanema foi o único local em que a irrigação foi utilizada.

Conduzida manualmente, a colheita foi realizada separadamente para plantas híbridas e para plantas provenientes de autofecundação, quando os grãos apresentavam ao redor de $18 \%$ de teor de água.

As espigas foram trilhadas, em debulhador manual, e, em seguida, procedeu-se à pesagem dos grãos. Durante a pesagem foram retiradas amostras dos grãos que acondicionadas em sacos plásticos, foram encaminhadas para a determinação do grau de umidade. $\mathrm{O}$ rendimento de grãos foi calculado, utilizando a fórmula indicada por TAVARES (1972), com peso corrigido para $13 \%$ de umidade.

\subsubsection{Determinações Pré-Colheita}

\section{a) População inicial:}

Foi determinado pela contagem do número de plantas emersas aos 30 dias após a data de semeadura.

\section{b) População final:}

Foi determinado pela contagem do número de plantas na ocasião da colheita. 


\section{c) Altura das plantas:}

Foi determinada com a medição da distância existente entre o nível do solo e a inserção da bainha da folha mais alta. Para isso, foram amostradas cinco plantas por parcela.

\section{d) Altura da espiga:}

Cinco plantas por parcela foram amostradas e as alturas das espigas foram determinadas tomando-se a distância entre o nível do solo e a inserção da espiga mais alta.

\section{e) Plantas quebradas e acamadas:}

Por ocasião da determinação da população final, foram contadas as plantas quebradas e acamadas. Foram consideradas acamadas as plantas que, não quebradas, formavam ângulo interno menor que 45 graus com o solo.

\subsubsection{Determinações Pós-Colheita}

\section{a) Produção de grãos por planta}

Foi determinada pelo quociente da produção de grãos pelo número de plantas obtidas na população final.

\section{b) Produção total de grãos}

Para a obtenção da produção total de grãos por parcela, foram somados os pesos de grãos provenientes de plantas híbridas e os de plantas autofecundadas. 
As determinações correspondentes à população inicial e final, altura das plantas, altura da espiga, plantas quebradas e acamadas e produção de grãos por planta, foram realizadas separadamente, dentro de cada parcela, para as plantas híbridas e para as provenientes de autofecundação. Tal procedimento foi adotado por permitir a avaliação do comportamento de tais plantas nos diferentes tratamentos, isoladamente.

\subsubsection{Análise dos Dados}

As análises de variância foram realizadas para cada local e, posteriormente considerando os quatro locais.

A análise dos dados, incluindo estudo de regressão para a produção total de grãos foi realizada por meio do Sistema de Análise Estatística SANEST para micro computadores (ZONTA et al., 1984). As médias foram comparadas pelo teste de Duncan ( $1 \%$ de probabilidade).

\subsection{Estudo de Metodologia para Avaliação da Pureza Genética}

Ensaios foram instalados objetivando levantar características morfológicas que pudessem ser utilizadas como marcadores para a identificação de sementes provenientes do parental fêmea autofecundado. Avaliações foram realizadas em sementes e em plantas em vários estádios de desenvolvimento. 


\subsubsection{Avaliação em Sementes}

Para a avaliação em sementes foi aplicada a técnica descrita por JUGENHEIMER (1958), utilizando solução de iodo.

Quatro repetições de 50 sementes, provenientes do parental fêmea autofecundado e híbridas foram seccionadas no sentido longitudinal para exposição dos endospermas. A seguir, foram acondicionadas em placas de petri imersas em solução de iodo a $4 \%$, durante cinco minutos. Após este período foi observado a coloração resultante da reação entre o iodo e o amido endospermático.

\subsubsection{Avaliação no Estádio de Plântulas}

Sementes híbridas e sementes provenientes do parental fêmea autofecundado foram semeadas em caixas plásticas distintas, contendo solo e areia na mesma proporção. A avaliação foi realizada, no terceiro dia após a emergência, quando os dois primeiros folíolos já se encontravam desenvolvidos.

Para a avaliação, as plântulas foram arrancadas e colocadas sobre superficie de cor branca formando quatro parcelas de 100 plântulas cada; cada parcela continha $20 \%$ de plântulas provenientes do parental fêmea autofecundado. Nestas condições, houve controle do número e da posição das plântulas provenientes do parental fêmea autofecundado na parcela.

Após a preparação das parcelas, três avaliadores, previamente informados das características que deveriam ser observadas, avaliaram cada plântula, julgando quais eram provenientes de sementes híbridas e quais eram provenientes do parental fêmea autofecundado. 
As características observadas para separação das plântulas foram as cores da bainha da primeira folha, do coleoptilo e da nervura central da primeira folha, todas relacionados à presença e à intensidade de antocianina. Observaramse, também, características, relacionadas ao vigor das plântulas, como número de folíolos expostos e ainda tonalidade da cor verde das folhas.

\subsubsection{Avaliação de Plantas no Campo}

Com o objetivo de verificar a possibilidade de diferenciação entre plantas provenientes de sementes híbridas e plantas provenientes do parental fêmea autofecundado, através de características morfológicas, foi instalado um experimento no campo em dezembro de 1993.

Foi utilizado o delineamento de blocos ao acaso, com quatro repetições, sendo cada parcela constituída por uma linha de $20 \mathrm{~m}$ de comprimento contendo $80 \%$ de plantas híbridas e $20 \%$ daquelas provenientes do parental fêmea autofecundado. A densidade foi de 5 plantas/metro, totalizando 100 plantas por parcela.

Os locais que continham sementes provenientes do parental fêmea autofecundado, foram marcados com estacas de bambu na semeadura. Por ocasião do desbaste, as estacas foram arrancadas e o controle da posição das plantas autofecundadas foi feito por meio de croqui.

Ao lado das linhas, nas quais foram realizadas as avaliações, foi semeada uma linha contendo, apenas, plantas provenientes do parental fêmea autofecundado de cada híbrido, objetivando facilitar a identificação destas quando 
misturadas às plantas híbridas na linha ao lado. O espaçamento entre as linhas foi de $1 \mathrm{~m}$.

As avaliações foram realizadas por três avaliadores que desconheciam a porcentagem existente de plantas provenientes do parental fêmea autofecundado. As plantas foram avaliadas individualmente e o avaliador apontava as plantas que julgava serem provenientes do parental fềmea autofecundado.

As plantas foram avaliadas quando apresentavam de 5-7 folhas, no florescimento, na colheita e em pós-colheita. Na primeira época as características avaliadas foram o vigor das plantas e o ângulo de inserção das folhas. Na segunda, foram avaliadas as cores da antera, dos estilo-estigmas e das glumas das flores masculinas, a precocidade no florescimento feminino e o vigor das plantas. Na colheita foram avaliados o vigor das plantas, o tamanho das espigas, a cor e o tipo de endosperma dos grãos. Em pós-colheita, avaliaram-se características da espiga.

\subsubsection{Análise dos Dados}

Foram calculadas as porcentagens de acerto e de erro durante as avaliações de pureza genética. A porcentagem de acerto foi calculada pelo quociente da freqüência observada pela freqüência esperada, multiplicado por cem.

No cálculo da porcentagem de erro foram computadas as plantas híbridas consideradas como provenientes do parental fêmea autofecundado e as plantas autofecundadas que deixaram de ser consideradas nas avaliações. $\mathrm{O}$ somatório dessas plantas foi dividido pelo número total de plantas na parcela e multiplicado por cem. 
Foi calculado o desvio padrão da média dos resultados obtidos nas quatro repetições obtidas pelos três avaliadores, conforme PIMENTEL GOMES (1987).

Para verificar a significância dos desvios, ocorridos entre os resultados obtidos pelos avaliadores foi utilizado o teste de qui-quadrado $\left(\lambda^{2}\right)$. Neste teste, os desvios foram transformados em um único valor de $\lambda^{2}$, representando a medida padronizada da magnitude dos desvios (RAMALHO et al., 1990).

$O$ valor de $\lambda^{2}$ foi estimado pela seguinte expressão:

$$
\lambda^{2}=\sum(\mathrm{Fo}-\mathrm{Fe})^{2} / \mathrm{Fe}
$$

sendo:

- Fo: freqüência observada de plantas provenientes de sementes do parental fêmea autofecundado.

- Fe: freqüência esperada de plantas provenientes de sementes do parental fêmea autofecundado.

Os dados de freqüência esperada e observada foram obtidos da média de quatro repetições para cada avaliador. 


\section{RESULTADOS E DISCUSSÃO}

\subsection{Avaliação da Qualidade Fisiológica}

Na Tabela 6 , estão apresentados os dados relativos ao resumo da análise de variância para os resultados dos testes de germinação, emergência em campo, de frio, de envelhecimento artificial e de condutividade elétrica.

Tabela 6. Resumo da análise de variância para os resultados do teste de germinação (TG-\%), emergência em campo (EC-\%), teste de frio (TF-\%), envelhecimento artificial (EA-\%) e condutividade elétrica (CE- $\mu \mathrm{mhos} / \mathrm{cm} / \mathrm{g}$ ). Piracicaba, 1994.

\begin{tabular}{|c|c|c|c|c|c|c|}
\hline \multirow[b]{3}{*}{ FV } & \multirow[b]{3}{*}{ GL } & \multicolumn{5}{|c|}{ Quadrados Médios } \\
\hline & & \multicolumn{2}{|c|}{ Germinação } & \multicolumn{3}{|c|}{ Vigor } \\
\hline & & TG & $\mathrm{EC}$ & TF & EA & $\mathrm{CE}$ \\
\hline Híbridos $(\mathrm{H})$ & 3 & $194,24 * *$ & $223,54 * *$ & $75,34^{* *}$ & $404,10^{* *}$ & $191,80^{* *}$ \\
\hline Taxas de Contaminação (C) & 4 & $20,77 * *$ & $38,47 * *$ & $17,80 * *$ & $41,73 * *$ & $0,52 \mathrm{NS}$ \\
\hline $\mathrm{H} \times \mathrm{C}$ & 12 & $6,77^{* *}$ & $14,49 * *$ & $7,95 * *$ & $32,92 * *$ & $1,94 * *$ \\
\hline Resíduo & 60 & 1,42 & 5,51 & 1,94 & 3,62 & 0,25 \\
\hline $\mathrm{CV}(\%)$ & & 1,24 & 2,54 & 1,44 & 1,99 & 6,37 \\
\hline Média & & 96,00 & 92,00 & 97,00 & 96,00 & 7,85 \\
\hline
\end{tabular}

** - significativo ao nível de $1 \%$ de probabilidade.

NS - não significativo.

Foram observadas diferenças significativas entre híbridos, taxas de contaminação e na interação híbridos x taxas de contaminação, com exceção do fator taxas de contaminação no teste de condutividade elétrica. 
Na Figura 9 estão apresentadas as médias das porcentagens de germinação. Para os híbridos C 701, C 425 e C 808 A, sementes provenientes do parental fêmea autofecundado, misturadas em diferentes proporções nos lotes de sementes híbridas, não influenciaram na germinação das sementes. No entanto, isso não foi verificado na mistura com o híbrido simples C 901; à medida em que foi aumentada a proporção de mistura foi observada redução da germinação.

Provavelmente, a redução da germinação, em lotes de híbridos simples, em função da contaminação, seja dependente da condição endogâmica do contaminante, que, neste caso é uma linhagem. Alguns autores têm enfatizado que as sementes das linhagens endogâmicas, na maioria das vezes, apresentam-se inferiores à de seus híbridos quanto à qualidade fisiológica (EAGLES \& HARDACRE, 1978; MARYAM \& JONES, 1983; SMITH \& WYCK, 1984; ROOD et al., 1990). O último autor atribuiu o fato à deficiência de giberelinas nas linhagens endogâmicas. BERNSTEN (1943), por outro lado considerou a maior mobilização de reservas do endosperma de sementes híbridas como sendo a promotora da diferenciação.

Os resultados observados mostraram haver manifestação da heterose na germinação de sementes de híbrido simples, indicando a participação do genótipo no desempenho.

Considerando os diferentes híbridos, observou-se menor germinação das sementes do híbrido C 901 (Figura 9). Diferenças, quanto a este parâmetro, não foram observadas entre os híbridos C 701, C 425 e 
C 808 A. Os resultados médios onde se aplicou o teste para a comparação de médias entre os híbridos também envolveram resultados das amostras contendo sementes provenientes do parental fêmea autofecundado, o que poderia ter contribuído para esse resultado. Entretanto, quando se comparou os resultados obtidos somente para as sementes híbridas ( $0 \%$ de contaminação), sementes do híbrido C 901 também apresentaram menor germinação.

A comparação entre genótipos foi possível em virtude do processo produtivo haver ocorrido em condições idênticas de área, tratos culturais, colheita, secagem e debulha.

Os resultados do teste de frio (Figura 10), indicaram que as taxas de contaminação não ocasionaram diferenças no vigor dos lotes dos híbridos C 701 e C 425 . No caso dos híbridos C 808 A e C 901, híbridos triplo e simples respectivamente, as contaminações de $100 \%$ promoveram redução no vigor. Estes resultados coincidem com os encontrados por PESEY (1970), uma vez que o autor encontrou maior tolerância ao frio nos híbridos simples em relação às suas linhagens parentais.

O híbrido simples C 901 , independentemente da taxa de contaminação apresentou menor vigor em relação aos híbridos duplos (C 701 e C 425) e triplo (C 808 A) (Figura 10). PESEY (1970), observou maior emergência de plântulas de híbridos duplos, do que em híbridos simples e linhagens, sob baixas temperaturas do solo. O mesmo autor considerou a existência de efeito maternal na tolerância ao frio. 
Figura 9. Resultados médios de germinação de sementes de milho (\%), pelo teste padrão, obtidos de diferentes híbridos sob diferentes taxas de contaminação. Piracicaba, 1994.

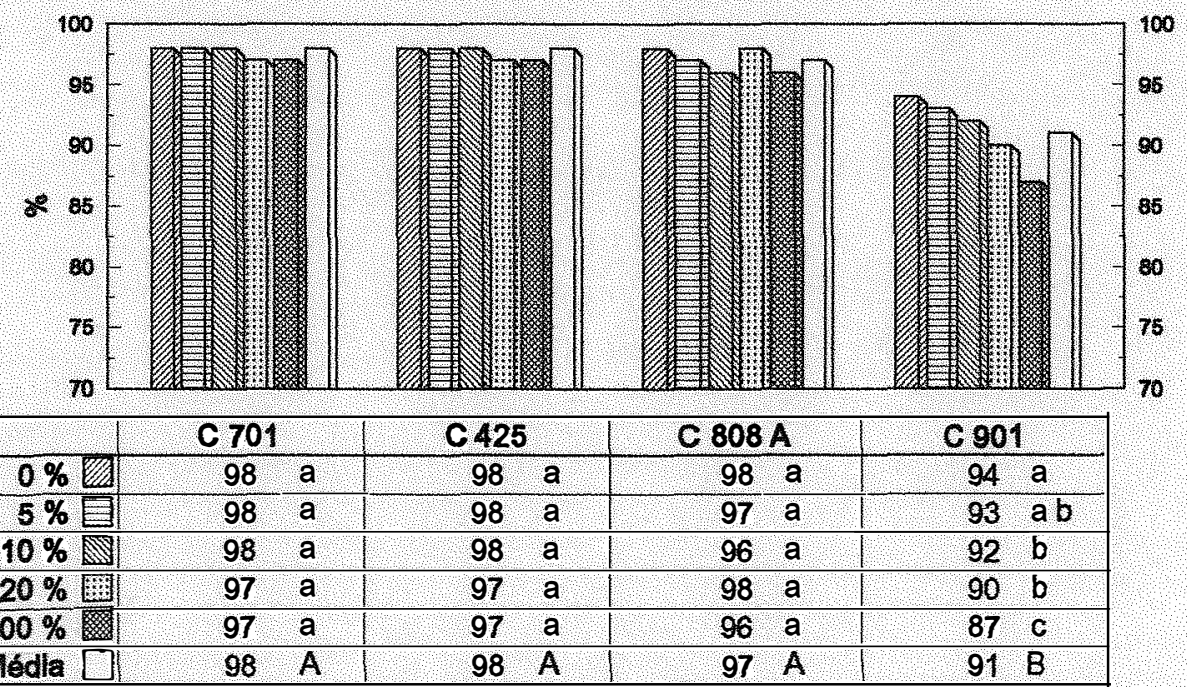

As médias seguidas das mesmas letras minusculas na coluna e maiúsculas na linha näo diferem entre si pelo teste de Duncan ao nivel de $1 \%$ de probabilidade.

Figura 10. Resultados médios de vigor de sementes de milho (\%), pelo teste de frio, obtidos de diferentes híbridos sob diferentes taxas de contaminação. Piracicaba, 1994.

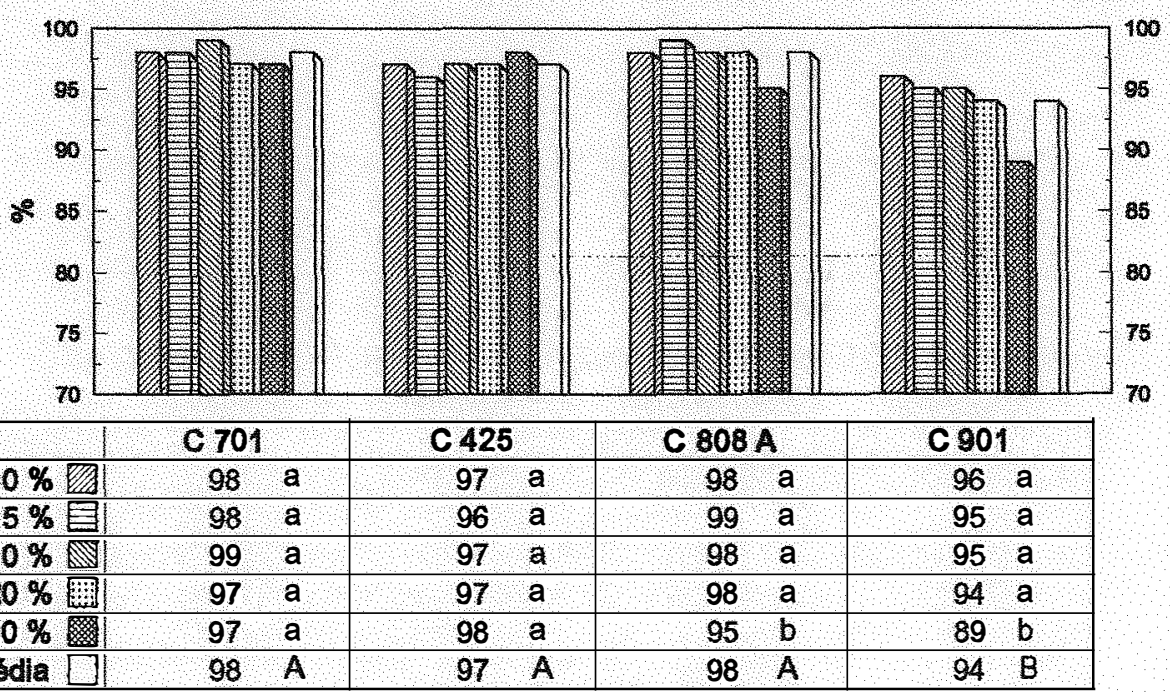

As medias seguidas das mesmas letras minúsculas na coluna e maiúsculas na linha não diferen entre si pelo teste de Duncan ao nivel de $1 \%$ de probabilidade. 
No presente trabalho, os tratamentos com $100 \%$ de contaminação, representaram lotes compostos, exclusivamente, de sementes dos parentais fêmeas autofecundados, que no caso do híbrido C 901, mostraram-se menos vigorosas nas condições proporcionadas pelo teste de frio. Considerando o efeito maternal na tolerância ao frio, a eventual menor tolerância da respectiva linhagem pode ter contribuído para a performance inferior do respectivo híbrido em relação aos demais. A depressão por endogamia mostrou-se mais efetiva no parental fêmea autofecundado do híbrido simples por ser uma linhagem; no entanto, misturas de sementes deste parental com sementes híbridas, em taxas de até $20 \%$, não reduziram o vigor do lote no teste de frio.

O teste de envelhecimento artificial (Figura 11) indicou, exclusivamente no híbrido C 901 , que o aumento da participação das sementes contaminantes no lote de sementes híbridas, levou à redução no vigor.

Sementes do híbrido simples C 901 ( $0 \%$ de contaminação) apresentaram-se menos vigorosas, no teste de envelhecimento artificial, do que as sementes dos híbridos C 701, C 425 e C 808 A. ODIEMAH (1991), encontrou da mesma forma, diferenças nas respostas de sementes de híbridos de milho submetidas ao teste de envelhecimento artificial. BASAVARAJAPPA (1991), no mesmo teste, observou superioridade das sementes do híbrido duplo em relação às dos híbridos simples. 
Quanto aos resultados do teste de emergência em campo (Figura 12), não foi verificada diferença entre as taxas de contaminação nos híbridos C 701, C 425 e C 808 A. No híbrido C 901 , o tratamento com $100 \%$ de contaminação foi inferior aos demais que, por sua vez, foram similares entre si. Neste teste, seguindo a tendência dos anteriores, as sementes puras $(0 \%$ de contaminação), do híbrido simples C 901 , apresentaram inferioridade em relação às dos demais.

O teste de condutividade elétrica acusou, em termos gerais, variação no vigor das sementes dos híbridos (Figura 13).

O comportamento do lote do híbrido C 901 , com $100 \%$ de contaminantes, apresentou menor condutividade elétrica do que nas demais taxas de contaminação, indicando superioridade de vigor. De acordo com os resultados obtidos nos demais testes, este resultado deveria ser o oposto; devido à ausência de trabalhos relacionados a esse assunto, torna-se difícil a discussão do resultado. No entanto, aparentemente, pode-se suspeitar de baixa relação entre o vigor genético dos híbridos e a integridade das membranas das sementes. Isto significa que não seria seguro comparar genótipos de milho, objetivando avaliação da qualidade fisiológica das sementes através do teste de condutividade elétrica.

Na Figura 14 estão apresentados os resultados médios, obtidos nos testes empregados para a avaliação da qualidade fisiológica de lotes de sementes com várias taxas de contaminação em diferentes híbridos. 
Figura 11. Resultados médios de vigor de sementes de milho (\%), pelo teste de envelhecimento artificial, obtidos de diferentes hibridos sob diferentes taxas de contaminação. Piracicaba, 1994.

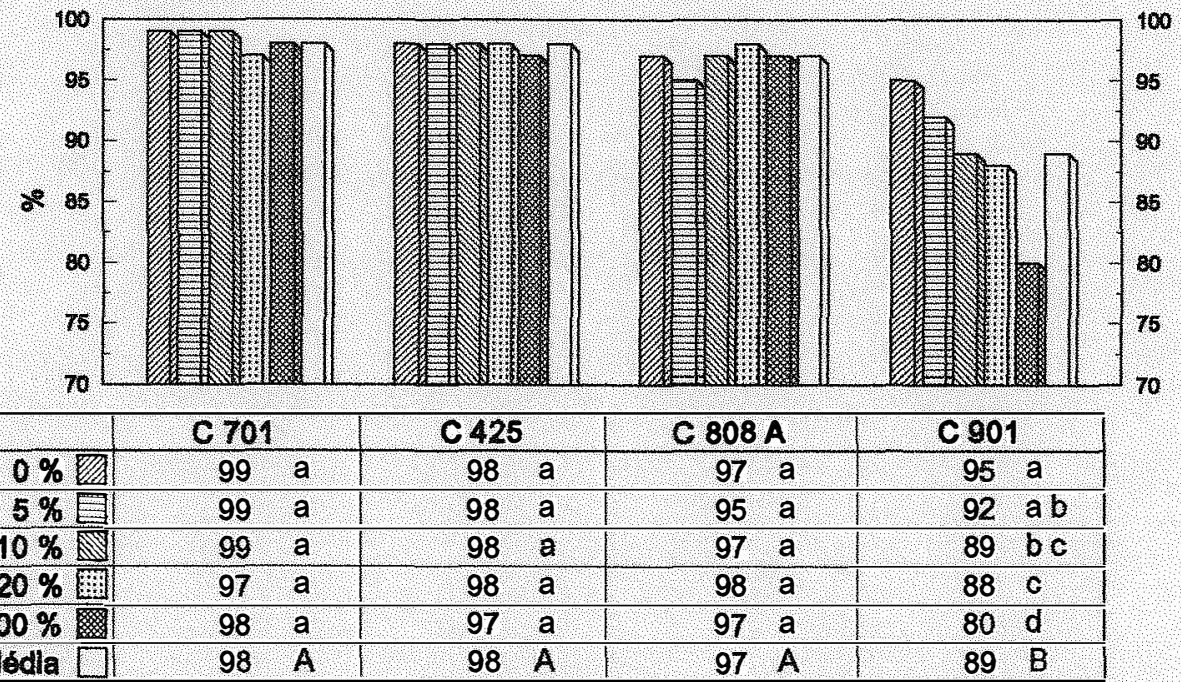

As médias seguidas das mesmas letras minúsculas na coluna e maiúsculas na linha năo diferem entre si pelo teste de Duncan ao nivel de $1 \%$ de probabilidade.

Figura 12. Resultados médios de germinação de sementes de milho (\%), pelo teste de emergência em campo, obtidos de diferentes híbridos sob diferentes taxas de contaminação. Piracicaba, 1994.

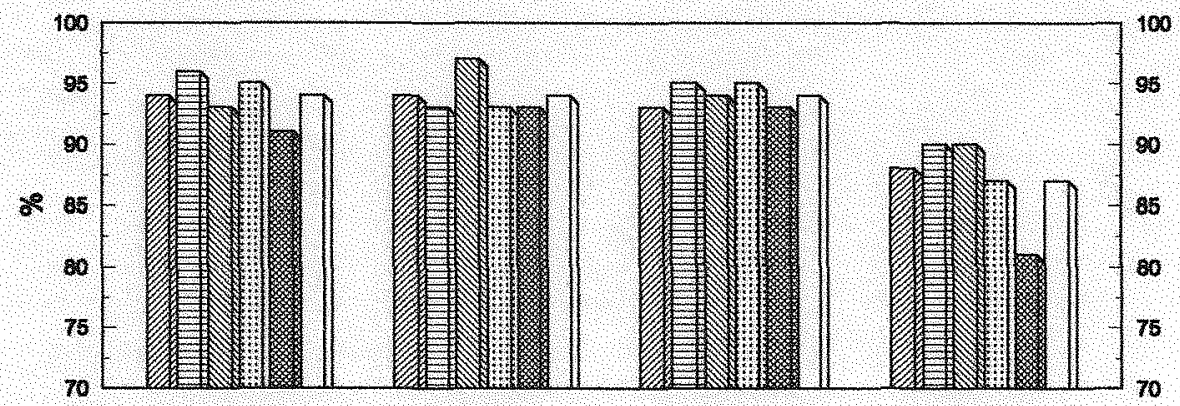

\begin{tabular}{|c|c|c|c|c|c|c|c|c|}
\hline & \multicolumn{2}{|c|}{ C 701} & \multicolumn{2}{|c|}{ C 425} & \multicolumn{2}{|c|}{ C $808 \mathrm{~A}$} & \multicolumn{2}{|c|}{ C 901} \\
\hline $0 \%$ & 94 & a & 94 & a & 93 & a & 88 & a \\
\hline $5 \% \square$ & 96 & a & 93 & a & 95 & a & 90 & a \\
\hline $10 \% \circlearrowleft$ & 93 & a & 97 & a & 94 & a & 90 & a \\
\hline $20 \%$ W & 95 & a & 93 & $a$ & 95 & a & 87 & a \\
\hline $100 \%$ & 91 & a & 93 & a & 93 & $a$ & 81 & $b$ \\
\hline Módia $\square$ & 94 & A & 94 & A & 94 & A & 87 & $\mathrm{~B}$ \\
\hline
\end{tabular}

As médias seguidas das mesmas letras minúsculas na coluna e maiúsculas na linha não diferem entre si pelo teste de Duncan ao nivel de $1 \%$ de probabilidade. 
Figura 13. Resultados médios de vigor de sementes de milho (Mmhos/cm/g), pelo teste de condutividade elétrica, obtidos de diferentes híbridos sob diferentes taxas de contaminação. Piracicaba, 1994.

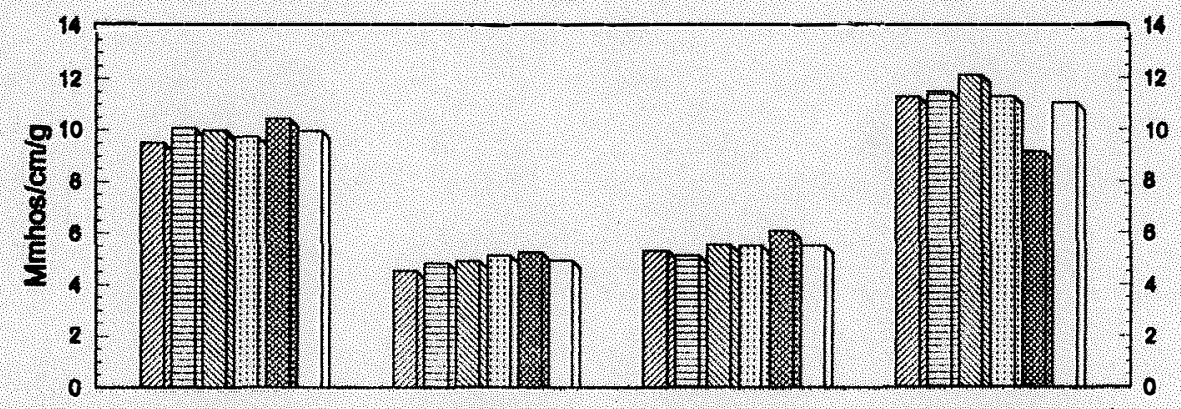

\begin{tabular}{|c|c|c|c|c|c|c|}
\hline & C701 & C425 & C $808 \mathrm{~A}$ & & C 901 & \\
\hline $0 \% \mathscr{Z}$ & 9,52 a & 4,53 ? & 5,31 & a & 11,26 & a \\
\hline $5 \%$ & 10,07 a & 4,82 & 5,12 & a & 11,46 & a \\
\hline $10 \%$ & 9,98 a & 4,87 ? & 5,54 & a & 12,11 & a \\
\hline $20 \%$ & 9,74 a & 5,10 ? & 5,50 & a & 11,28 & a \\
\hline $100 \%$ 列 & 10,45 a & 5,25 . & 6,06 & a & 9,14 & b \\
\hline Médla & $9,95 \mathrm{~B}$ & 4,91 C & 5,50 & C & 1105 & $\mathrm{~A}$ \\
\hline
\end{tabular}

As médias seguidas das mesmas letras minúsculas na coluna e maiúsculas na linha náo diferem entre si pelo teste de Duncan ao nivel de $1 \%$ de probabilidade.

Figura 14. Resultados médios de germinação de sementes de milho, pelo teste padrão $(\%)$ e emergência em campo $(\%)$ e de vigor, pelo teste de frio (\%), envelhecimento artificial (\%), e condutividade elétrica (Mmhos/cm/g) sob diferentes taxas de contaminação e híbridos. Piracicaba, 1994.

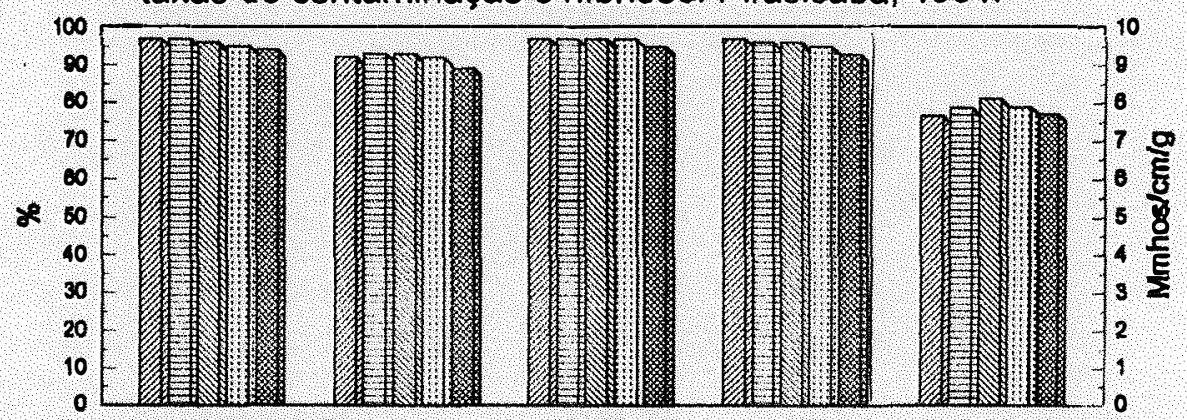

\begin{tabular}{|c|c|c|c|c|c|}
\hline & T. GERM. & EMER. CAM. & T. FRIO & ENV. ART. & CON. ELET \\
\hline $0 \%$ V & 97,00 a & $92,00 \quad a$ & 97,00 a & 97,00 a & 7,65 a \\
\hline $6 \% \Xi$ & 97,00 a b & 93,00 a & 97,00 a & 96,00 a & 7,86 a \\
\hline $10 \%$ & $96,00 \mathrm{~b}$ & 93,00 a & 97,00 a & 96,00 a & 8,12 a \\
\hline 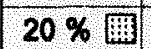 & $95,00 \quad b$ & 92,00 a & 97,00 a & 95,00 a & 7,90 a \\
\hline $100 \%$ 国 & $94,00 \mathrm{c}$ & $89,00 \mathrm{~b}$ & 95,00 b & $93,00 \mathrm{~b}$ & $7.72 \mathrm{a}$ \\
\hline
\end{tabular}

As médias seguidas das mosmas letras minúsculas na coluna năo diferem entre si pelo teste de Duncan ao nivel de $1 \%$ de probabilidade. 
Ao mesmo tempo em que a elevação da taxa de contaminação prejudicou a germinação, a emergência em campo e o vigor (testes de frio, envelhecimento artificial) foram afetados de modo negativo, exclusivamente, nos tratamentos com contaminações de $100 \%$ (Figura 14).

Os resultados, apresentados na Figura 14, representam a média conjunta dos híbridos. Assim, houve a interferência dos resultados obtidos com $100 \%$ de contaminação do híbrido C 901 que, representando uma linhagem, foram inferiores em todos os testes utilizados para a avaliação da qualidade físiológica.

\subsection{Ensaio de Campo}

Na Tabela 7, está apresentado o resumo da análise de variância para os resultados de alturas de plantas, espigas e produção de grãos por planta. Para todos os parâmetros estudados verificou-se efeitos significativos para locais, híbridos, taxas de contaminação e interação entre os fatores, com exceção da interação tripla.

Na Figura 15 estão apresentados os resultados médios de altura das plantas híbridas em populações com diferentes taxas de contaminação com plantas autofecundadas. Para todos os híbridos estudados, a altura de plantas não variou entre os tratamentos com contaminações de até $20 \%$ que, por sua vez superaram o de $100 \%$. 


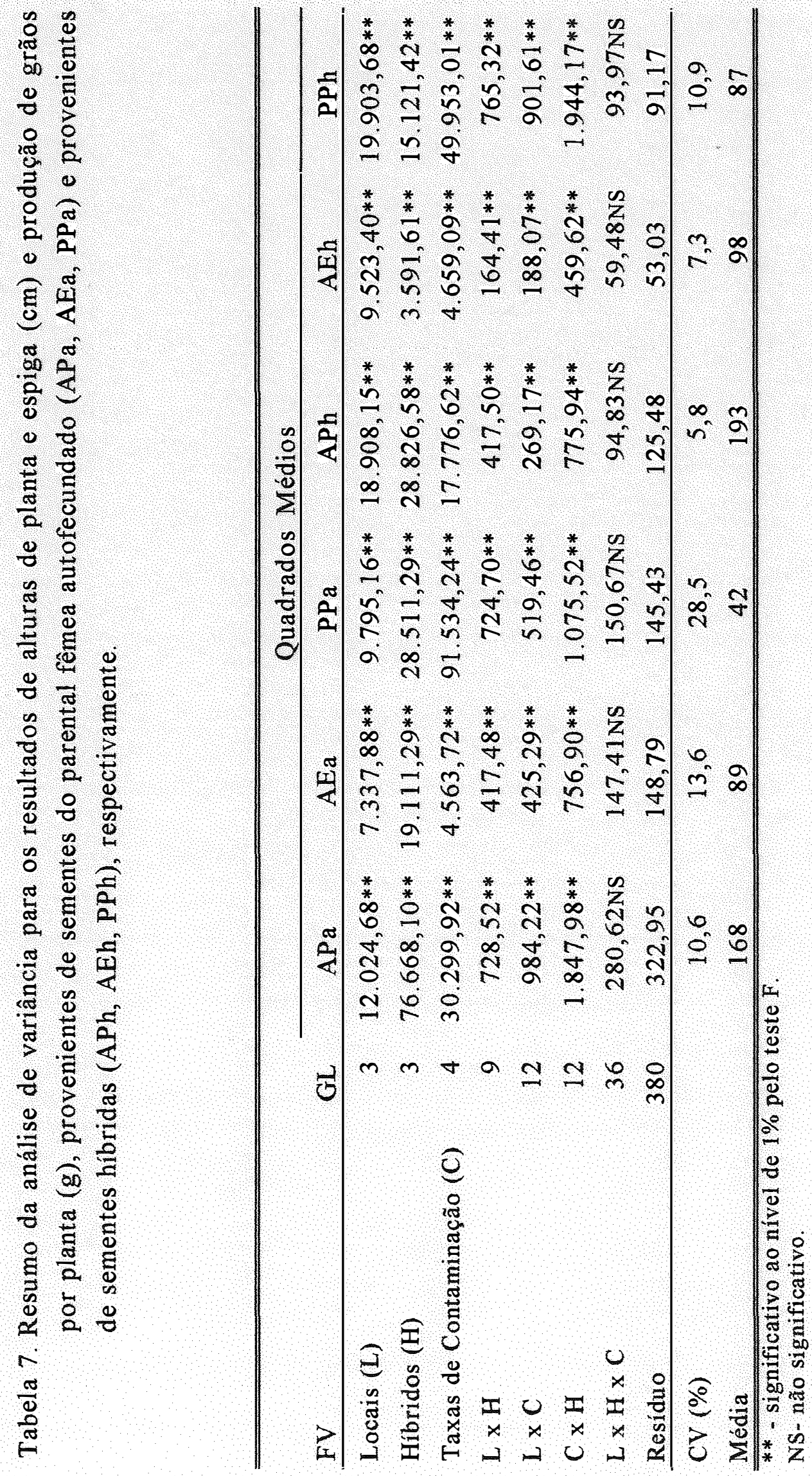


As plantas híbridas, por serem mais vigorosas, apresentaram maior altura independentemente da taxa de contaminação de plantas provenientes do parental fêmea autofecundado. Em várias pesquisas, envolvendo autofecundação, foi observada redução no vigor das plantas decorrente da depressão por endogamia (SHULL, 1909; JUGENHEIMER, 1958; HALLAUER \& MIRANDA FILHO, 1981). A inferioridade de altura, observada em plantas provenientes do parental fềmea autofecundado, representou a redução no vigor oriunda da depressão por endogamia, que se constitui no processo inverso da heterose.

Os resultados apresentados na Figura 16 referem-se às alturas de plantas autofecundadas que atuaram, em diferentes taxas, como contaminantes em populações de plantas híbridas. Resultados de altura de plantas foram maiores quando os tratamentos apresentavam contaminação de 0 $\%$, ou seja, $100 \%$ de sementes híbridas. A altura de plantas autofecundadas nos híbridos C 701 e C 901 foi maior nos tratamentos contendo $100 \%$ de contaminação. A altura das plantas autofecundadas foi sendo elevada à medida em que a concorrência, com as plantas híbridas, foi diminuindo. As plantas híbridas, por serem mais vigorosas, competem por água, luz e nutrientes, desfavorecendo o desenvolvimento das plantas contaminantes.

Os resultados de altura das plantas autofecundadas nos híbridos C 425 e C 808 A, não apresentaram diferenças entre os tratamentos, significando que as plantas autofecundadas não foram influenciadas, na altura, pela competição com as plantas híbridas. 
Figura 15. Resultados médios de altura de plantas hibridas $(\mathrm{cm}) \mathrm{em}$ populações com diferentes taxas de contaminação com plantas provenientes de autofecundação.

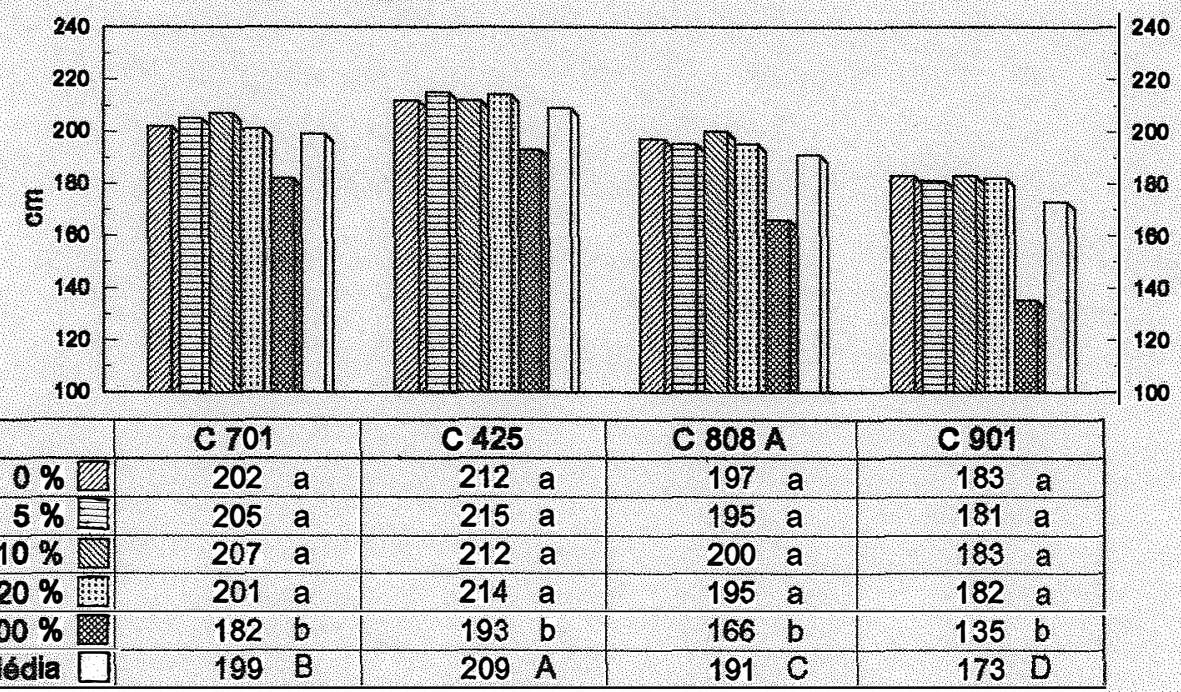

As médias seguidas das mesmas letras minúsculas na coluna e maiúsculas na linha nâo diferem entre si pelo teste de Duncan ao nivel de $1 \%$ de probabilidade.

Figura 16. Resultados médios de altura de plantas autofecundadas $(\mathrm{cm})$ atuando como contaminantes, em diferentes taxas, em populações de plantas hibridas.

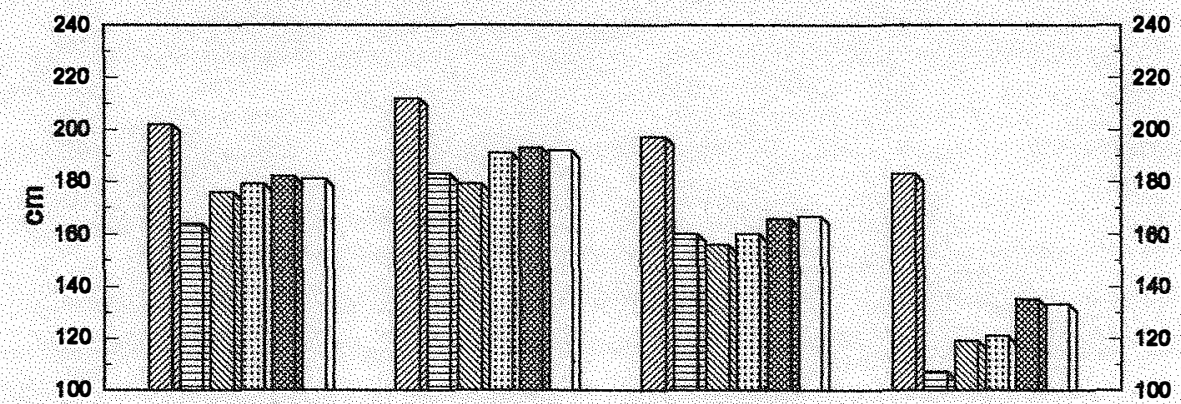

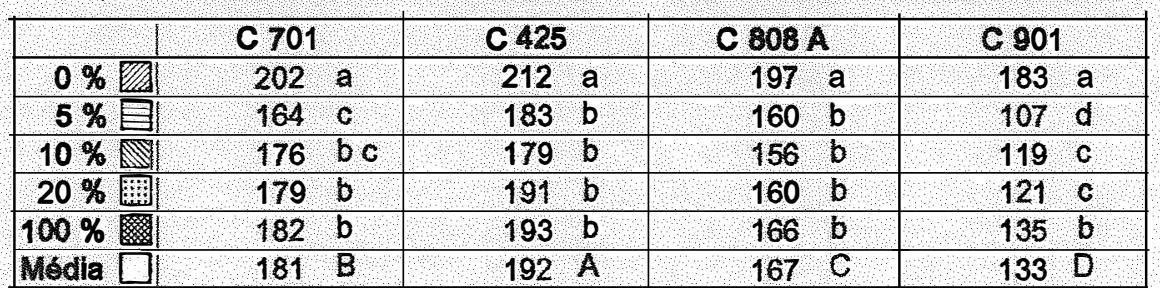

As módias seguidas das mesmas letras minúsculas na coluna e maiúsculas na linha näo díferem entre si pelo teste de Duncan ao nivel de $1 \%$ de probabilidade. 
WERF et al. (1989) observaram reduções de 40-45 kg/ha na produção de matéria verde para cada $1 \%$ de elevação na taxa de participação de plantas autofecundadas em populações de plantas híbridas. Ao considerar a altura de plantas, como um dos fatores influenciadores do peso de matéria verde, os resultados obtidos no presente trabalho, mostraram que a redução desta, decorrente da presença de plantas oriundas de sementes provenientes do parental fêmea autofecundado, depende da capacidade de competição destas plantas com as plantas híbridas.

A comparação entre as alturas das plantas híbridas com as autofecundadas indicou diferenças aproximadas, em favor das primeiras, de 20 cm (C 701 e C 425), $31 \mathrm{~cm}$ (C 808 A) e de $48 \mathrm{~cm}$ (C 901). A desuniformidade na altura de plantas, em uma lavoura, é um fator negativo quanto ao aspecto, além de poder proporcionar redução no rendimento de matéria verde, importante característica em lavouras destinadas à silagem.

Nas Figuras 17 e 18 estão apresentados os resultados de altura das plantas híbridas e autofecundadas combinadas, populacionalmente, em diferentes locais. Independentemente do local, a altura das plantas no híbrido C 425 foi superior, seguida pelas dos híbridos C 701 e C 808 A; a menor altura foi observada no híbrido C 901 . Maior altura de planta proveniente tanto de sementes híbridas como de sementes do parental fêmea autofecundado foi observado em Paranapanema seguido por Ituverava, Guaíra e Piracicaba (Figuras 17 e 18). As precipitações pluviais ocorridas durante o ciclo da cultura em Paranapanema (Figura 6) provavelmente tenham contribuído para o melhor desenvolvimento das plantas. 
Figura 17. Resultados médios de altura de plantas híbridas $(\mathrm{cm})$ de diferentes hibridos de milho em diferentes locais.

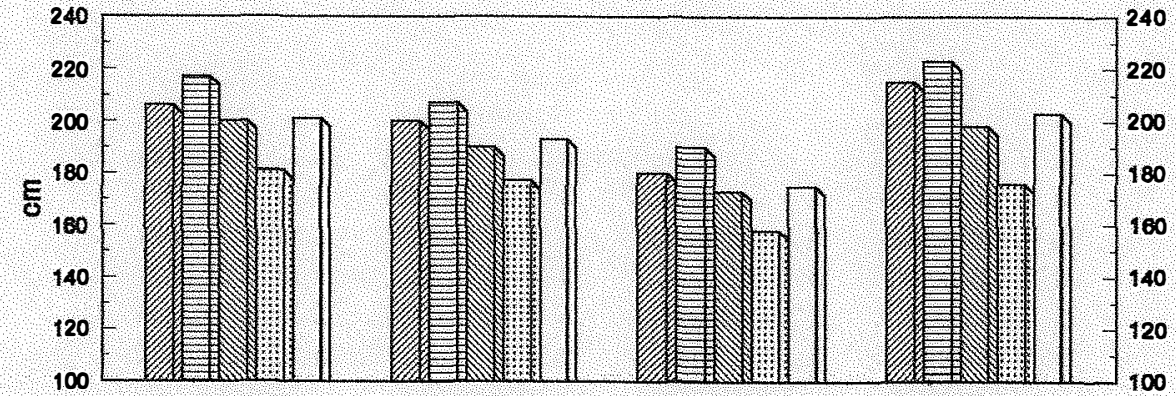

\begin{tabular}{|c|c|c|c|c|}
\hline & ITUVERAVA & GUAIRA & PIRACICABA & PARANAPANEMA \\
\hline C 701 V & 206 b & 200 a & $180 \mathrm{~b}$ & $215 \mathrm{~b}$ \\
\hline C $425 \square$ & 217 a & 207 a & 190 a & 223 a \\
\hline C $808 \mathrm{~A}$ & $200 \mathrm{c}$ & $190 \mathrm{~b}$ & $173 \mathrm{~b}$ & 198 c \\
\hline C 901 汗 & $181 \mathrm{~d}$ & $177 \mathrm{C}$ & 158 c & $176 d$ \\
\hline Módia $\square$ & $201 \mathrm{~A}$ & $193 \mathrm{~B}$ & $175 \mathrm{C}$ & 203 A \\
\hline
\end{tabular}

As médias seguidas das mesmas letras minúsculas na coluna e maiúsculas na linha não diferem entre si pelo teste de Duncan ao nivel de $1 \%$ de probabilidade.

Figura 18. Resultados médios de altura de plantas $(\mathrm{cm})$ provenientes do parental fêmea autofecundado de diferentes híbridos em diferentes locais.

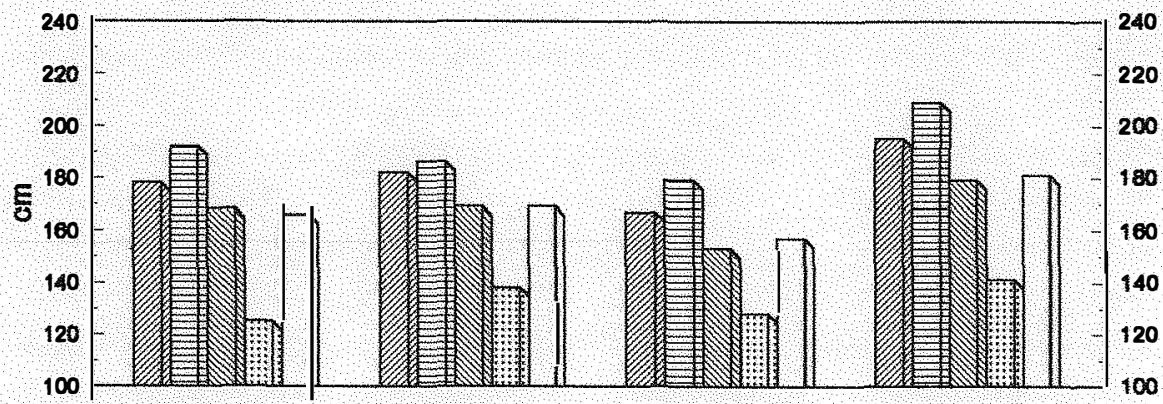

\begin{tabular}{|c|c|c|c|c|}
\hline & ITUVERAVA & GUAIRA & PIRACICABA & PARANAPANEMA \\
\hline C 701 Q & $178 \mathrm{~b}$ & 182 a & 167 a & $195 \mathrm{~b}$ \\
\hline C 425 $⿴$ & 192 a & 186 a & 179 a & $209 a$ \\
\hline C 808 AN & $168 \mathrm{~b}$ & $169 \mathrm{~b}$ & $153 \mathrm{~b}$ & 179 c \\
\hline $\mathrm{C} 901 \mathrm{~B}$ & $125 \mathrm{c}$ & $138 \mathrm{c}$ & $128 \mathrm{C}$ & $141 \mathrm{~d}$ \\
\hline Média $\square$ & 166 B & $169 \mathrm{~B}$ & $157 \mathrm{C}$ & $181 \mathrm{~A}$ \\
\hline
\end{tabular}

As médias seguidas das mesmas letras minúsculas na coluna e maiúsculas na linha não diferem entre si pelo teste de Duncan ao nivel de $1 \%$ de probabilidade. 
A altura das plantas híbridas, nas populações com diferentes taxas de plantas autofecundadas, em diferentes locais, está apresentada na Figura 19. Em todos os locais, as taxas de 5,10 e $20 \%$ de plantas autofecundadas não provocaram diferenças em relação à população exclusivamente formada por plantas híbridas. Contudo, populações com $100 \%$ de plantas autofecundadas foram mais baixas que as demais.

Os resultados de altura das plantas autofecundadas, distribuidas, como contaminantes, em diferentes taxas na população de plantas híbridas, em diferentes locais, estão apresentados na Figura 20. Em Ituverava a altura das plantas foi sendo reduzida à medida em que foi diminuindo a taxa de contaminação. Assim, a competição com plantas híbridas dificultou o crescimento das autofecundadas. Nos demais locais não houve diferenças entre tratamentos.

Os resultados de altura de espiga das plantas híbridas e das plantas autofecundadas, distribuidas em diferentes taxas populacionais, estão apresentados respectivamente, nas Figuras 21 e 22. Para os híbridos C 701, C 808 A e C 901 os tratamentos com $0,5,10$ e $20 \%$ de contaminação não apresentaram diferença quanto à altura de espiga de plantas híbridas (Figura 21).

Os resultados apresentados na Figura 22 mostraram que a altura de espiga de plantas contaminantes ( $100 \%$ de contaminação) foi menor que a altura de espiga de plantas híbridas ( $0 \%$ de contaminação), exceção feita para o híbrido C 425 , onde não foi verificado diferença entre os tratamentos. 
Figura 19. Resultados médios de altura de plantas hibridas $(\mathrm{cm})$ em populações com diferentes taxas de contaminação com plantas provenientes de autofecundação em diferentes locais.

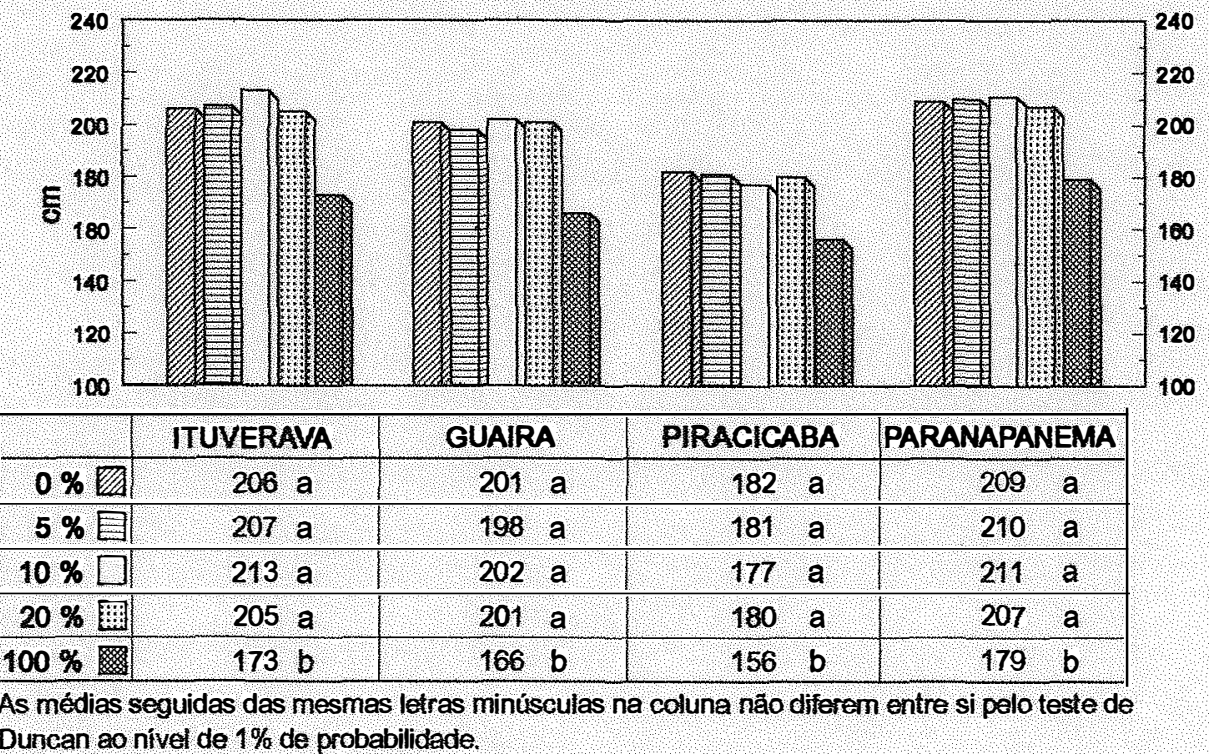

Figura 20. Resultados médios de altura de plantas autofecundadas $(\mathrm{cm})$ atuando como contaminantes, em diferentes taxas, em populações de plantas híbridas em diferentes locais.

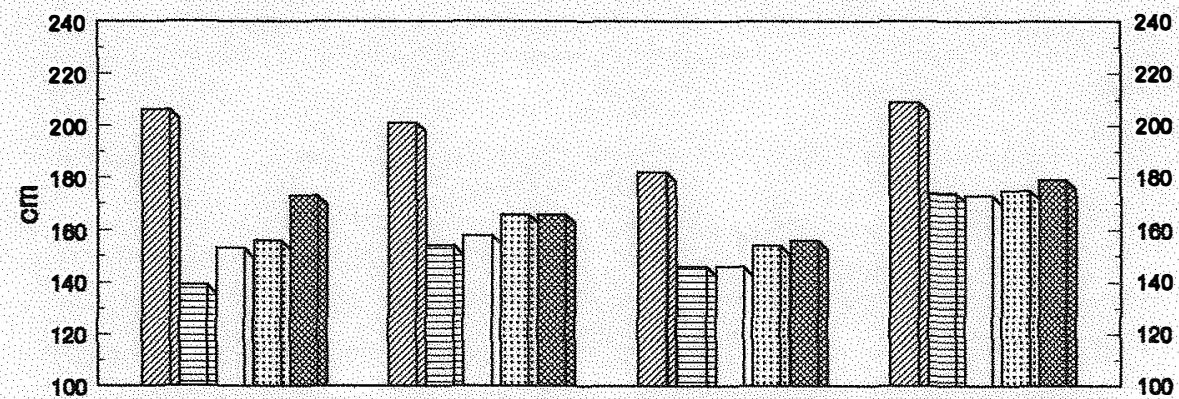

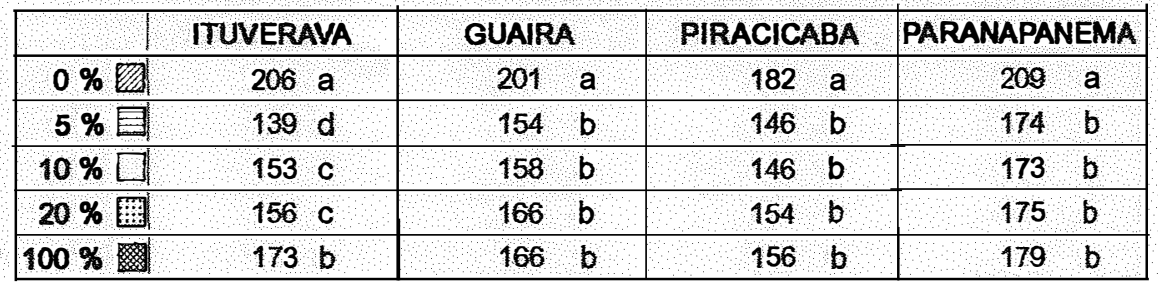

As médias seguidas das mesmas letras minúsculas na coluna não diferem entre si pelo teste de Duncan ao nivel de $1 \%$ de probabilidade. 
Figura 21. Resultados médios de altura de espiga de plantas híbridas (cm) em populações com diferentes taxas de contaminação com plantas provenientes de autofecundação.

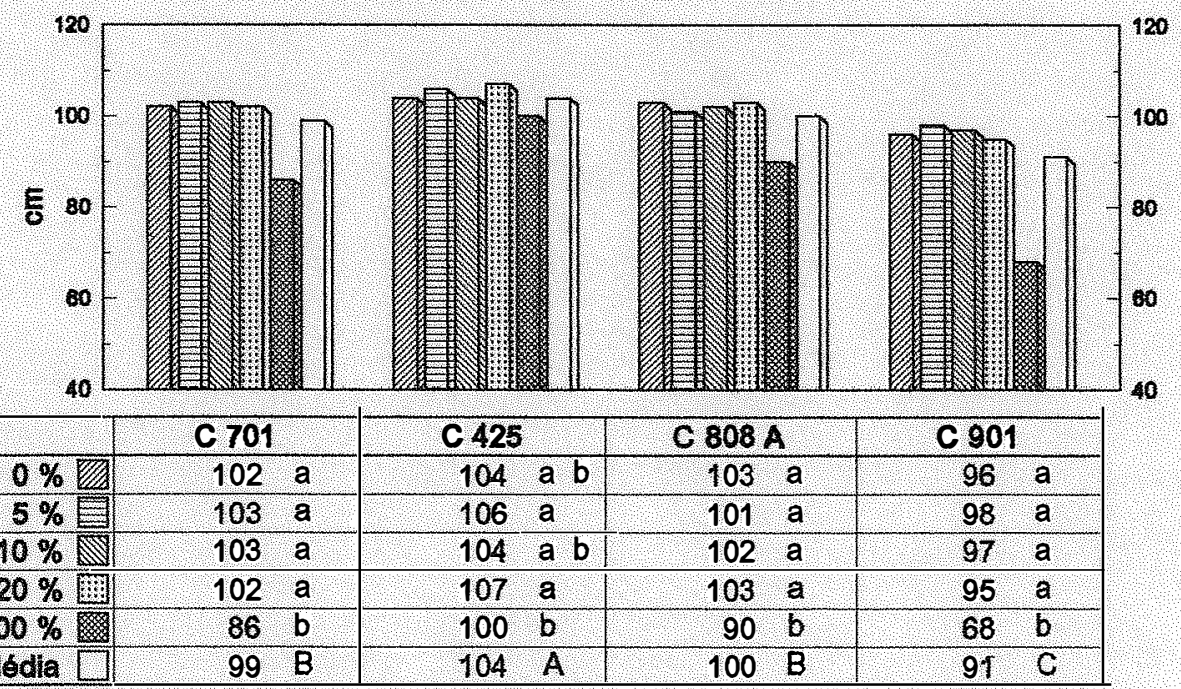

As médias seguidas das mesmas letras minúsculas na coluna e maiúsculas na linha náo diferem entre si pelo teste de Duncan ao nivel de $1 \%$ de probabilidade.

Figura 22. Resultados médios de altura de espiga de plantas autofecundadas $(\mathrm{cm})$ atuando como contaminantes, em diferentes taxas, em populações de plantas híbridas.

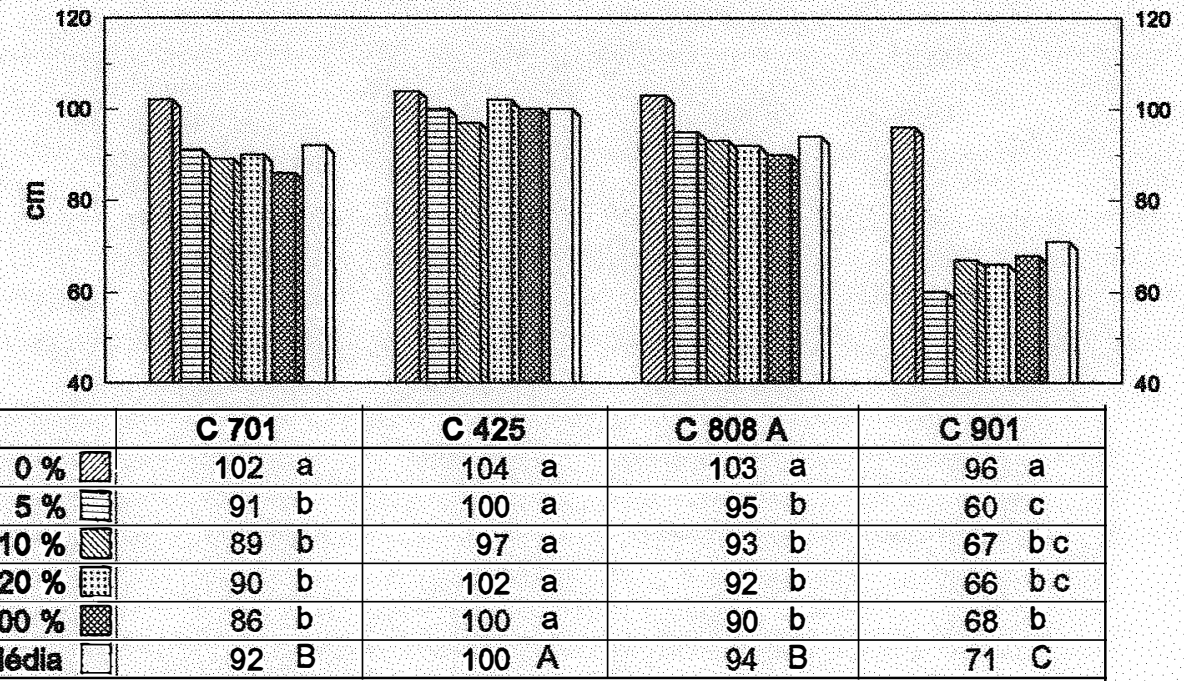

As médias seguidas das mesmas letras minúsculas na coluna e malúsculas na linha não diferem entre si pelo teste de Duncan ao nivel de $1 \%$ de probabilidade. 
Nos híbridos C 701, C 425 e C 808 A, não houve variação na altura de espiga das plantas autofecundadas entre tratamentos com $5,10,20$ e $100 \%$ de contaminação. No híbrido C 901, a altura de espiga tendeu a aumentar com a redução da contaminação (Figura 22) indicando, da mesma forma que o verificado com a altura de plantas, que a elevação da competição com as plantas híbridas reduziu a altura de espiga das plantas autofecundadas. As plantas híbridas, por serem mais altas e vigorosas do que as autofecundadas competem por luz, água e nutrientes desfavorecendo o desenvolvimento das plantas provenientes de autofecundação.

Ao analisar os dados da altura de espiga obtidos em plantas híbridas ( $0 \%$ de contaminação) e em plantas provenientes de autofecundação (100\% de contaminação), verificou-se maior altura de espiga em favor das plantas híbridas (Figura 22).

Com base nestes resultados, são esperadas variações na altura das espigas em populações híbridas contaminadas por plantas autofecundadas; esta desuniformidade, além de afetar negativamente o aspecto da lavoura, pode dificultar a operacionalização das máquinas de colheita.

Os resultados de altura de espiga de plantas híbridas e autofecundadas, em diferentes locais, são apresentados nas Figuras 23 e 24 respectivamente. A altura de espiga de plantas híbridas foi maior no híbrido C $425 \mathrm{em}$ todos os locais, não havendo, entretanto, diferença estatística em relação ao híbrido C 808 A (Figura 23 ). 
Figura 23. Resultados médios de altura de espigas de plantas híbridas $(\mathrm{cm})$ de diferentes híbridos de milho em diferentes locais.

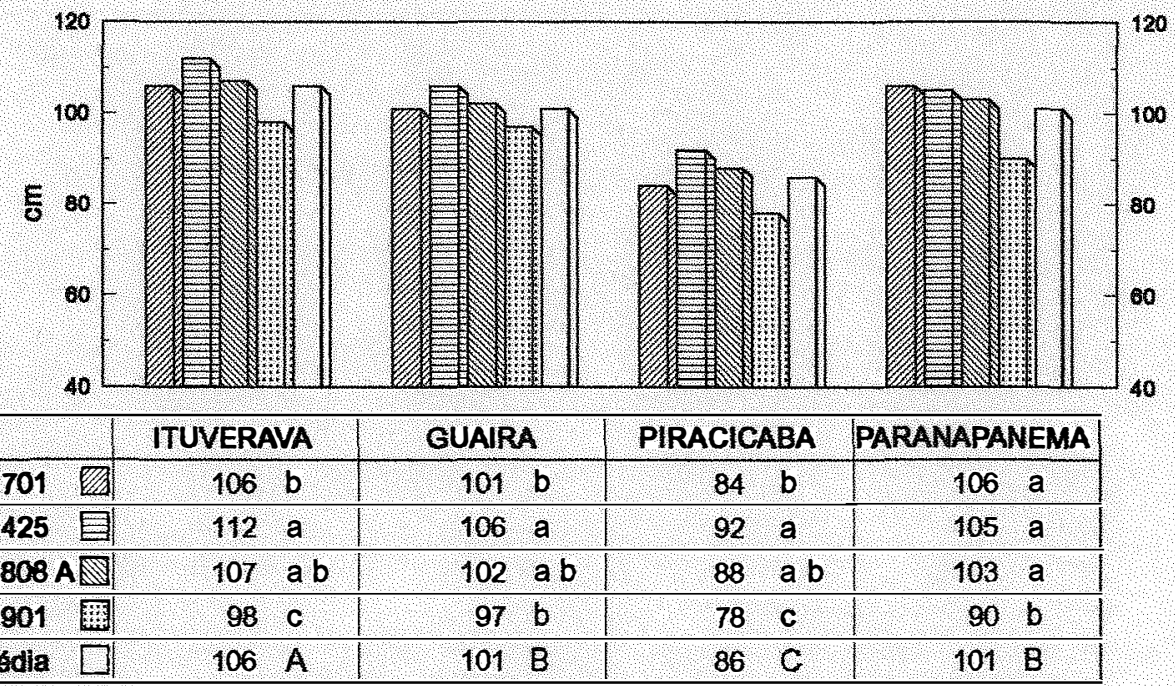

As médias seguidas das mesmas letras minúsculas na coluna e maiúsculas na linha não diferem entre si pelo teste de Duncan ao nivel de $1 \%$ de probabilidade.

Figura 24. Resultados médios de altura de espiga de plantas (cm) provenientes do parental fêmea autofecundado de diferentes híbridos em diferentes locais.

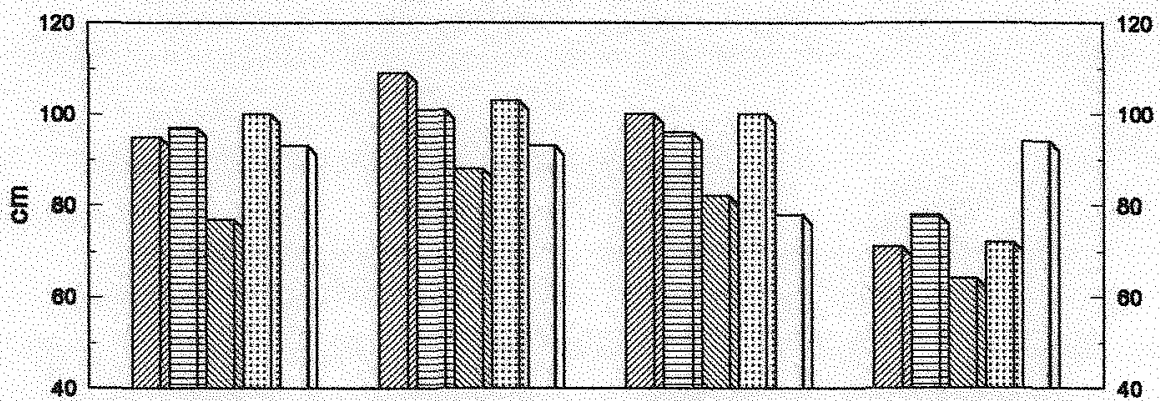

\begin{tabular}{|c|c|c|c|c|c|c|c|c|}
\hline & \multicolumn{2}{|c|}{ ITUVERAVA } & \multicolumn{2}{|c|}{ GUAIRA } & \multicolumn{2}{|c|}{ PIRACICABA } & \multicolumn{2}{|c|}{ PARANAPANENA } \\
\hline C 701 Ш & 95 & b & 109 & a & 100 & b & 71 & a \\
\hline C 425 回 & 97 & a & 101 & a & 96 & a & 78 & a \\
\hline C $808 \mathrm{~A}$ & 77 & $a b$ & 88 & a & 82 & a b & 64 & a \\
\hline C 901 国 & 100 & c & 103 & b & 100 & c & 72 & b \\
\hline Médla $\square$ & 93 & A. & 93 & A & 78 & B & 94 & A \\
\hline
\end{tabular}

As médias seguidas das mesmas letras minúsculas na coluna e maiúsculas na linha não diferem entre si pelo teste de Duncan ao nivel de $1 \%$ de probabilidade. 
Em Paranapanema a altura de espigas desses híbridos não se diferenciou da do híbrido C 701. O híbrido C 901 apresentou a menor altura de espiga, independentemente do local (Figura 23).

A altura de espiga das plantas autofecundadas não apresentou diferenças estatísticas entre os híbridos C 701, C 425 e C 808 A em Guaíra e Paranapanema (Figura 24). Em Piracicaba e Ituverava houve superioridade no híbrido C 425 , que não diferiu estatisticamente do híbrido C $808 \mathrm{~A}$, que por sua vez, não diferiu do híbrido C 701. Em todos os locais, foi observada inferioridade no híbrido C 901.

De uma maneira geral a altura de espiga, tanto de plantas híbridas como de plantas contaminantes, foi maior no híbrido C 425 , seguido pelos híbridos C 701 e C 808 A que não diferiram entre si. Menor altura de espiga foi observada no híbrido C 901 (Figuras 23 e 24).

A menor altura de espigas foi observada em Piracicaba (Figuras 23 e 24). Analisando os dados apresentados na Figura 25 foi observada em todos os locais, menor altura de espiga no tratamento com $100 \%$ de contaminação, em relação aos demais.

Os dados de altura de espiga de plantas autofecundadas, distribuidas em variadas taxas em populações de plantas híbridas, em diferentes locais, estão apresentados na Figura 26. Em Ituverava, Piracicaba e em Paranapanema, os tratamentos com 5, 10, 20 e $100 \%$ de contaminação foram equivalentes. 
Figura 25. Resultados médios de altura de plantas hibridas $(\mathrm{cm}) \mathrm{em}$ populações com diferentes taxas de contaminação com plantas provenientes de autofecundação.

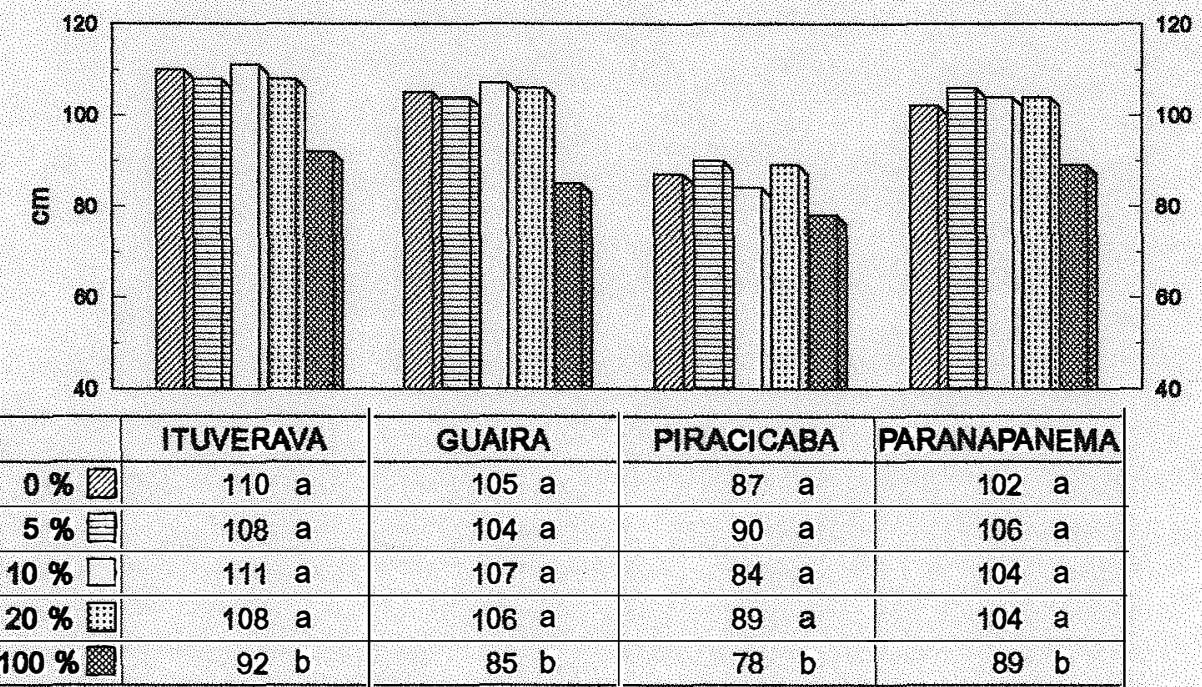

As médias seguidas das mesmas letras minúsculas na coluna não diferem entre si pelo teste de Duncan ao nivel de $1 \%$ de probabilidade.

Figura 26. Resultados médios de altura de plantas autofecundadas $(\mathrm{cm})$ atuando como contaminantes, em diferentes taxas, em populações de plantas híbridas.

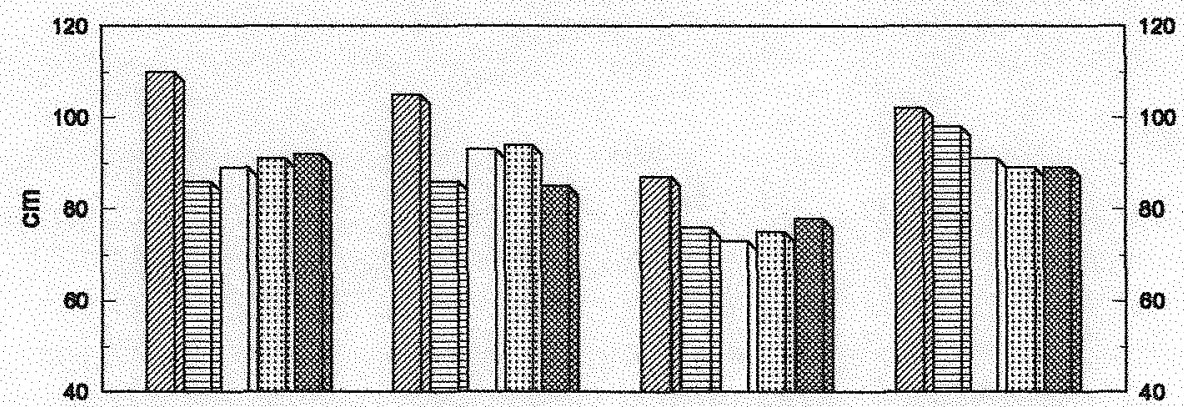

\begin{tabular}{|c|c|c|c|c|}
\hline & ITUVERAVA & GUAIRA & PIRACICABA & PARANAPANEMA \\
\hline $0 \%$ & $110 \mathrm{a}$ & 105 a & 87 a & 102 a \\
\hline $5 \%$ & $86 \mathrm{~b}$ & $86 \mathrm{bc}$ & $76 \mathrm{~b}$ & 98 a b \\
\hline $10 \% \square$ & $89 \mathrm{~b}$ & $93 \mathrm{bc}$ & $73 \mathrm{~b}$ & $91 \mathrm{~b}$ \\
\hline $20 \%$ 冊 & $91 \mathrm{~b}$ & 94 b & $75 \mathrm{~b}$ & $89 \mathrm{~b}$ \\
\hline $100 \%$ & $92 \mathrm{~b}$ & 85 c & $78 \quad \mathrm{ab}$ & $89 b$ \\
\hline
\end{tabular}

As médias seguidas das mesmas letras minúsculas na coluna não diferem entre si pelo teste de Duncan ao nivel de $1 \%$ de probabilidade. 
Escassez de trabalhos relacionados ao assunto, limita a discussão desses resultados. CAPELARO (1992) avaliou as alturas de espiga e de planta de híbridos, que durante o processo de produção de sementes, sofreram diferentes taxas de despendoamento sem que, contudo, fosse conhecido o nível de contaminação provocado, por falta do controle da polinização. As alturas de espiga e de plantas híbridas foram maiores que os observados em plantas autofecundadas em três dos quatro híbridos estudados.

Na presente pesquisa foi observada menores alturas de planta e de espiga nas plantas contaminantes em relação às híbridas.

A Figura 27 apresenta os resultados de produção de grãos por planta híbrida, em vários híbridos, em populações com diferentes taxas de contaminação. Nos híbridos C 425 e C 808 A, os tratamentos com $0,5,10$ e $20 \%$ de contaminação foram equivalentes entre si e superaram em todos os híbridos o de $100 \%$.

O principal efeito, esperado com a heterose, é o aumento no rendimento. Autofecundações conduzem à perdas de vigor e à consequente redução de rendimento. O nível de redução, com a endogamia, varia com o genótipo envolvido.

Plantas híbridas, dos híbridos C 701 e C 901, apresentaram comportamento diferenciado na produção de grãos por planta que tendeu a decrescer com a redução da participação de plantas contaminantes na população (Figura 27); neste caso a presença de plantas contaminantes menos vigorosas e menos competitivas podem ter favorecido o desenvolvimento 
e a produção das plantas híbridas. Os dados de produção de grãos por planta autofecundada (Figura 28), indicaram menor produção nos tratamentos com 5,10 e $20 \%$ em relação aos demais, em todos os híbridos, o que confírma a capacidade de compensação produtiva presumida para as plantas híbridas. Esta situação seria comparada à da encontrada nas falhas de estande em que a capacidade de compensação da planta depende do genótipo. Como observado na Figura 27, a capacidade de compensação, das plantas híbridas, nos híbridos C 425 e C 808 A não foi expressiva, apesar da redução produtiva das plantas autofecundadas quando distribuidas entre os híbridos (Figura 28). Este comportamento foi similar ao observado na altura de plantas (Figura 26).

De uma maneira geral, houve maior produção de grãos por planta híbrida no híbrido C 808 A, seguido pelos híbridos C 701, C 901 e C 425 (Figura 27). A produção de grãos por planta contaminante foi maior no híbrido C 808 A, seguido pelos cultivares C 701, C 425 e C 901 (Figura 28).

Na Figura 29, estão apresentados os dados de produção de grãos por planta híbrida dos híbridos em diferentes locais. Observou-se, de uma maneira geral, maior produção no híbrido C 808 A em relação aos demais e menor produção no híbrido C 425. A produção de grãos por planta contaminante, na maior parte dos casos foi maior no híbrido C 808 A seguido pelo híbrido C 701 e menor no híbrido C 901 (Figura 30). A menor produção, observada para plantas contaminantes do híbrido C 901 , era esperada por se tratar de linhagem, que geralmente, abriga genótipo desfavorável à produtividade. 
Figura 27 . Resultados médios de produção de grãos por planta híbrida (g) em populações com diferentes taxas de contaminação com plantas provenientes de autofecundação.

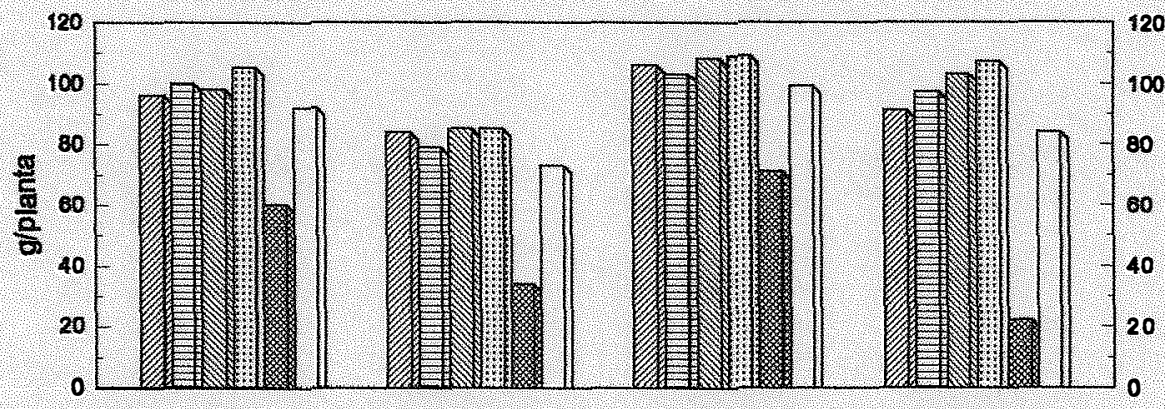

\begin{tabular}{|c|c|c|c|c|c|}
\hline & C 701 & C 425 & C 808 A & C 901 & \\
\hline $0 \%$ & 96 b & & $106 \quad \mathrm{a}$ & 91 & c \\
\hline $5 \%$ 目 & $100 \mathrm{ab}$ & 79 & $103 \mathrm{a}$ & 97 & $\mathrm{bcc}$ \\
\hline $10 \% \mathbb{\mathbb { N }}$ & $98 \mathrm{ab}$ & 85 & $108 \quad a$ & 103 & $a b$ \\
\hline $20 \%$ & 105 a & 85 & $109 \mathrm{a}$ & 107 & a \\
\hline $100 \%$ 圂 & $60 \mathrm{c}$ & 34 & & 22 & d \\
\hline Média L & 92 B & $73 \mathrm{C}$ & $99 \mathrm{~A}$ & 84 & C \\
\hline
\end{tabular}

As médias seguidas das mesmas letras minúsculas na coluna e maiúsculas na linha não diferem entre si pelo teste de Duncan ao nivel de $1 \%$ de probabilidade.

Figura 28. Resultados médios de produção de grãos por planta autofecundada (g) atuando como contaminante, em diferentes taxas, em populações de plantas híbridas.

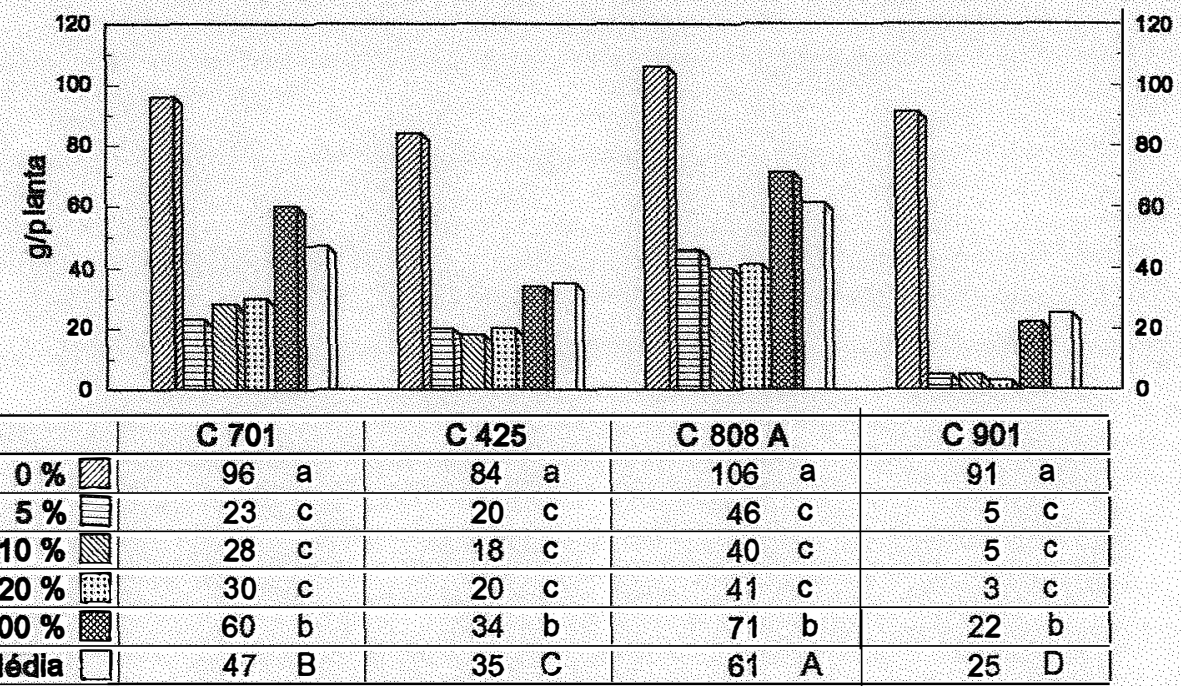

As médias seguidas das mesmas letras minúsculas na coluna e maiúsculas na linha não diferem entre si pelo teste de Duncan ao nivel de $1 \%$ de probabilidade. 
Figura 29. Resultados médios de produção de grãos por planta híbrida (g) de diferentes hibridos de milho em diferentes locais.

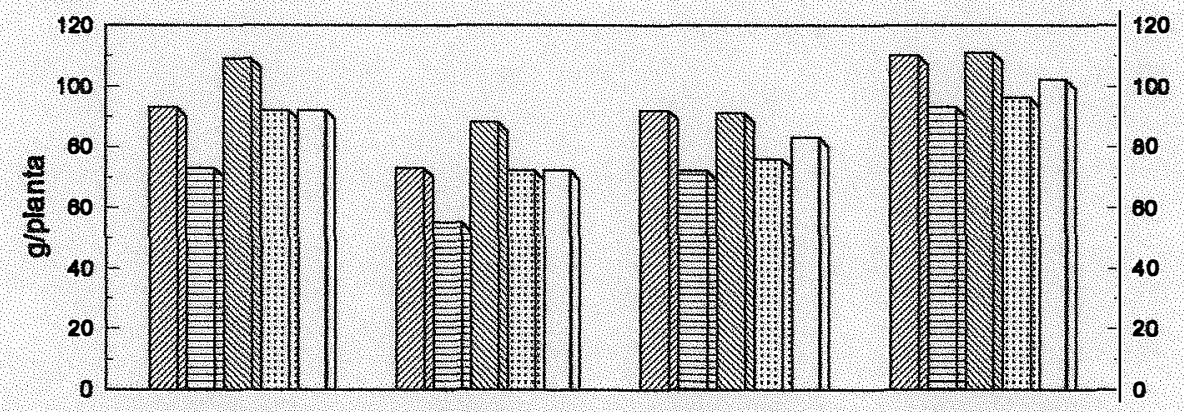

\begin{tabular}{|c|c|c|c|c|}
\hline & ITUVERAVA & GUAIRA & PIRACICABA & PARANAPANEMA \\
\hline C 701 D & $93 \mathrm{~b}$ & $73 \mathrm{~b}$ & 92 a & 110 a \\
\hline C 425 目 & $73 \mathrm{C}$ & 55 C & $72 \mathrm{C}$ & $93 \quad b$ \\
\hline C 808 A & 109 a & 88 a & 91 a & 111 a \\
\hline C 901 北 & $92 \mathrm{~b}$ & $72 \mathrm{~b}$ & 76 b & $96 \mathrm{~b}$ \\
\hline Media $\square$ & $92 \mathrm{~B}$ & $72 \mathrm{D}$ & $83 \mathrm{C}$ & $102 \mathrm{~A}$ \\
\hline
\end{tabular}

As médias seguidas das mesmas letras minúsculas na coluna e maiúsculas na linha não diferem entre si pelo teste de Duncan ao nivel de $1 \%$ de probabilidade.

Figura 30. Resultados médios de produção de grãos por planta (g) proveniente do parental fêmea autofecundado de diferentes híbridos de milho em diferentes locais.

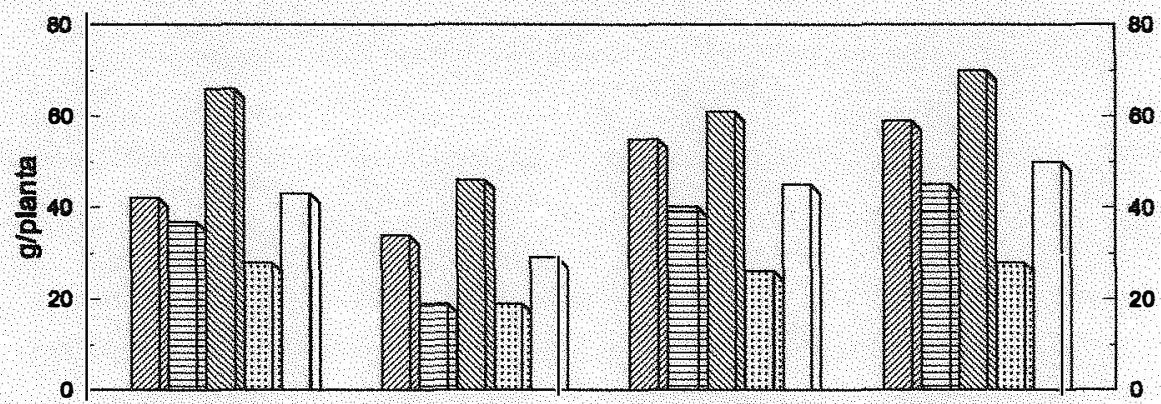

\begin{tabular}{|c|c|c|c|c|}
\hline & ITUVERAVA & GUAIRA & PIRACICABA & PARANAPANEMA \\
\hline c 701 Q & $42 \mathrm{~b}$ & $34 \mathrm{~b}$ & 55 b & 59 b \\
\hline C 425 圆 & $37 \mathrm{c}$ & 19 C & 40 C & $45 c$ \\
\hline C 808 A@ & 66 a & 46 a & 61 a & 70 a \\
\hline C901 [in] & $28 \mathrm{~d}$ & 19 C & $26 d$ & $28 d$ \\
\hline Media $\square$ & $43 \mathrm{~B}$ & $29 \mathrm{C}$ & $45 \mathrm{~B}$ & $50 \mathrm{~A}$ \\
\hline
\end{tabular}

As médias seguidas das mesmas letras minúsculas na coluna e maiúsculas na linha não diferem entre si pelo teste de Duncan ao nivel de $1 \%$ de probabilidade. 
Os dados de produção de grãos por planta híbrida, em população com diferentes taxas de contaminação, estão apresentados na Figura 31 para cada local. Independentemente dos híbridos, os dados obtidos em Piracicaba não apresentaram diferenças significativas entre contaminações. Nos demais locais, os tratamentos com $20 \%$ de contaminação proporcionaram maior produção por planta híbrida, sendo que este não diferiu estatisticamente do tratamento com $10 \%$ de contaminação em Ituverava, Guaíra e Paranapanema, e ainda do tratamento com $5 \%$ de contaminação em Paranapanema. Em Ituverava e Guaíra menor produção de grãos por planta foi observada no tratamento com $0 \%$ de contaminação.

Na produção de grãos por planta contaminante, observou-se que os tratamentos com $100 \%$ de contaminação foram superiores aos demais. Não foram verificadas diferenças entre os tratamentos com 5,10 e $20 \%$ de contaminação (Figura 32). A produção de grãos de plantas híbridas (nível $0 \%$ de contaminação) superou invariavelmente todos os demais tratamentos.

Na Tabela 8, está apresentado o resumo da análise de variância para os resultados de produção total de grãos dos híbridos apresentando diferentes níveis de misturas decorrente de autofecundação e para plantas acamadas e quebradas provenientes de sementes híbridas e de sementes do parental fêmea autofecundado.

Para os parâmetros, produção total de grãos e porcentagem de plantas acamadas e quebradas provenientes de autofecundação (PQa) verificaram-se efeitos significativos para local, híbrido, taxas de contaminação e interação entre os fatores, com exceção da interação tripla. 
Figura 31. Resultados médios de produção de grãos por planta híbrida (g) em populações com diferentes taxas de contaminação com plantas provenientes de autofecundação em diferentes locais.

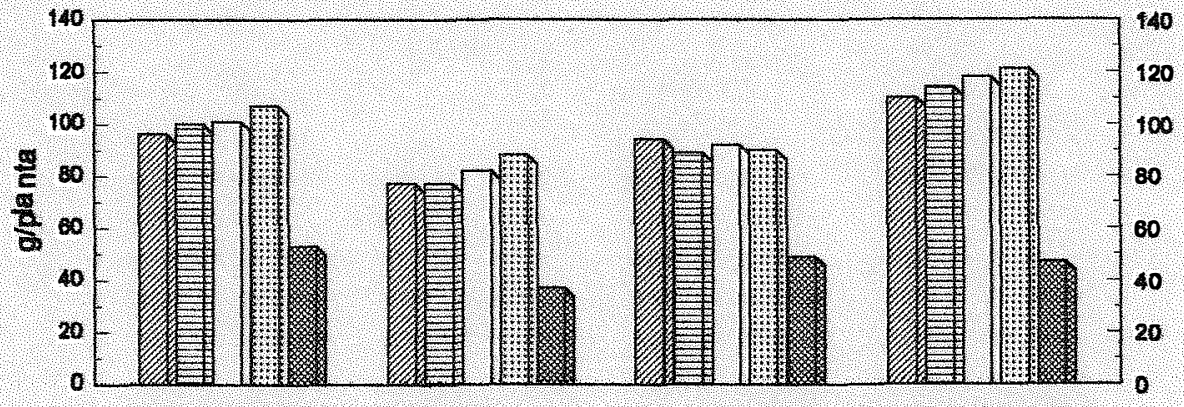

\begin{tabular}{|c|c|c|c|c|c|c|c|c|}
\hline & \multicolumn{2}{|c|}{ ITUYERAVA } & \multicolumn{2}{|c|}{ GUAIRA } & \multicolumn{2}{|c|}{ PIRACICABA } & \multicolumn{2}{|c|}{ PARANAPANEMA } \\
\hline $0 \%$ & 96 & b & 77 & b & 94 & a & 110 & b \\
\hline $5 \%$ & 100 & b & 77 & b & 89 & a & 114 & a b \\
\hline $10 \% \square$ & 101 & $a b$ & 82 & $a b$ & 92 & a & 118 & a \\
\hline $20 \%$ 嘈 & 107 & a & 88 & a & 90 & a & 121 & a \\
\hline $100 \%$ & 53 & c & 37 & c & 49 & b & 47 & c \\
\hline
\end{tabular}

As médias seguidas das mesmas letras minúsculas na coluna não diferem entre si pelo teste de Duncan ao nivel de $1 \%$ de probabilidade.

Figura 32. Resultados médios de produção de grãos por planta autofecundada (g) atuando como contaminante, em diferentes taxas, em populações de plantas híbridas em diferentes locais.

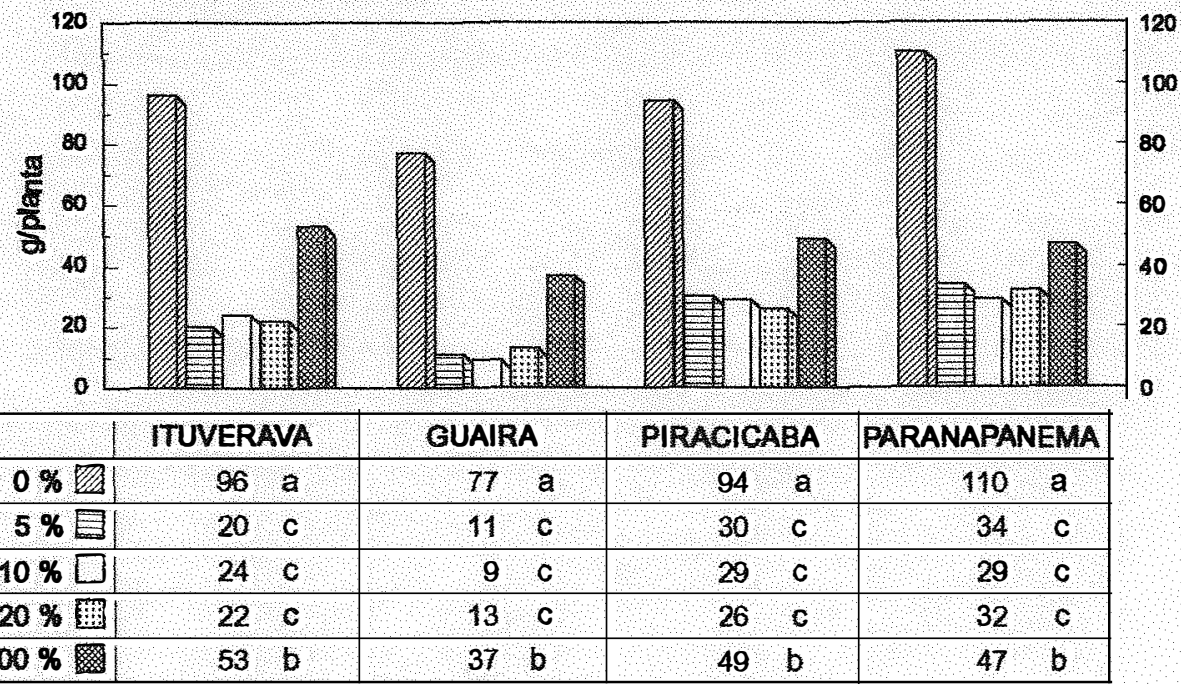

As médias seguidas das mesmas letras minúsculas na coluna não diferem entre si pelo teste de Duncan ao nivel de $1 \%$ de probabilidade. 
Para o parâmetro porcentagem de plantas acamadas e quebradas provenientes de sementes híbridas, observaram-se efeitos significativos para locais, híbridos, interações locais $\mathrm{x}$ híbridos e híbridos $\mathrm{x}$ taxas de contaminação.

Tabela 8. Resumo da análise de variância para os resultados de produção total de grãos (kg/ha) (PTG) e de plantas acamadas e quebradas (\%) obtidas de sementes do parental fêmea autofecundado (PQa) e de sementes híbridas (PQh).

\begin{tabular}{lcrrrr}
\hline & & \multicolumn{4}{c}{ Quadrados Médios } \\
\cline { 2 - 6 } F V & GL & \multicolumn{1}{c}{ PTG } & PQa & PQh \\
\hline Locais (L) & 3 & $6.222 \times 10^{* *}$ & $67 \times 10^{-3 * *}$ & $48 \times 10^{-3 * *}$ \\
Híbridos (H) & 3 & $5.265 \times 10^{* *}$ & $1 \times 10^{-3 * *}$ & $3 \times 10^{-3} 3^{* *}$ \\
Taxas de Contaminação (C) & 4 & $12.097 \times 10^{* *}$ & $5 \times 10^{-3} * *$ & $25 \times 10^{-5} \mathrm{NS}$ \\
L x H & 9 & $205 \times 10^{* *}$ & $1 \times 10^{-3 * *}$ & $1 \times 10^{-3 * *}$ \\
H x C & 12 & $609 \times 10^{* *}$ & $1 \times 10^{-3 *}$ & $33 \times 10^{-5 *}$ \\
L x C & 12 & $234 \times 10^{* *}$ & $1 \times 10^{-3 * *}$ & $83 \times 10^{-6} \mathrm{NS}$ \\
L x H x C & 36 & $231 \times 10^{3} \mathrm{NS}$ & $30 \times 10^{-5} \mathrm{NS}$ & $19 \times 10^{-6} \mathrm{NS}$ \\
Resíduo & 380 & $239 \times 10^{3}$ & $31 \times 10^{-5}$ & $12 \times 10^{-5}$ \\
\hline C V (\%) & & 10,76 & 40,45 & 32,15 \\
Média & & $4.548,62$ & 27,96 & 17,30 \\
\hline \hline
\end{tabular}

**- significativo ao nível de $1 \%$ de probabilidade.

* - significativo ao nível de $5 \%$ de probabilidade.

NS- não significativo.

Na Figura 33 estão apresentados os resultados médios de produção total de grãos dos híbridos obtidos sob diferentes taxas de contaminação. Para o híbrido C 701 , não houve diferença significativa quanto à produção de grãos entre os tratamentos com 0 e $5 \%$ de contaminação. Redução de $7,3 \%$ correspondendo à $394 \mathrm{~kg} / \mathrm{ha}$ foi observada no tratamento com $20 \%$ de contaminação, em relação ao tratamento com $0 \%$ de 
contaminação. Para o mesmo híbrido, plantas provenientes do parental fêmea autofecundado produziram $40 \%$ menos do que as híbridas.

O tratamento com $5 \%$ de contaminação reduziu $8,5 \%$ o rendimento de grãos do híbrido C 425 , sendo que este tratamento não diferiu estatisticamente do tratamento com $10 \%$ e $20 \%$ de contaminação. Redução de $621 \mathrm{~kg} / \mathrm{ha}$ correspondendo a $13,3 \%$ da produção foi observada em tratamentos com $20 \%$ de contaminação. No tratamento com $100 \%$ de plantas provenientes do parental fêmea autofecundado houve redução de $40 \%$ no rendimento, correspondendo ao mesmo valor em porcentagem que o apresentado para 0 híbrido C 701.

Figura 33. Resultados médios de produção total de grãos ( $\mathrm{kg} / \mathrm{ha}$ ) obtidos de diferentes híbridos de milho sob diferentes taxas de contaminação.

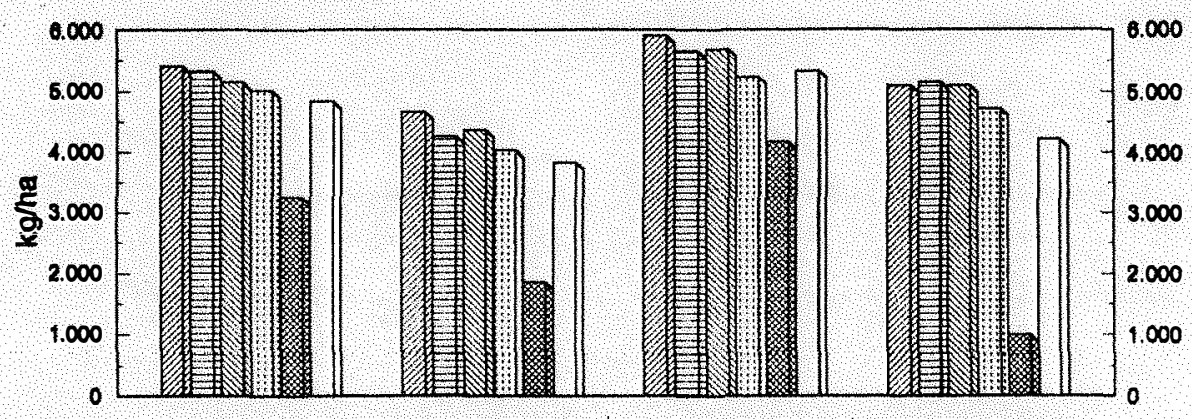

\begin{tabular}{|c|c|c|c|c|c|c|c|c|}
\hline & C 701 & & C 425 & & C $808 \mathrm{~A}$ & & C 901 & \\
\hline $0 \% \mathbb{Z}$ & 5.404 & a & 4.653 & a & 5.895 & a & 5.097 & $a$ \\
\hline $5 \%$ 目 & 5.330 & a & 4.257 & bc & 5.657 & a & 5,146 & $a$ \\
\hline $10 \% \mathbb{\mathbb { N }}$ & 5.139 & $a b$ & 4.362 & b & 5.687 & a & 5.087 & a \\
\hline $20 \%$ & 5.010 & b & 4.032 & c & 5.231 & b & 4.709 & $b$ \\
\hline $100 \%$ & 3.251 & c & 1.857 & d & 4.174 & C & 993 & C \\
\hline Médla $\square$ & 4.827 & B & 3.829 & D & 5.329 & A & 4.206 & C \\
\hline
\end{tabular}

As médias seguidas das mesmas letras minúsculas na coluna e maiúsculas na linha năo diferem entre si pelo teste de Duncan ao nivel de $1 \%$ de probabilidade. 
Os resultados de rendimento de grãos apresentados na Figura 33 para o híbrido C 808 A mostraram redução na produção de $11,2 \%$ correspondendo a $664 \mathrm{~kg} / \mathrm{ha}$ em populações de plantas híbridas com $20 \%$ de plantas provenientes do parental fềmea autofecundado. O tratamento com $100 \%$ de contaminação reduziu o rendimento em $29 \%$, quando comparado ao do tratamento com $0 \%$ de contaminação. Entretanto, não foi observada diferença estatística significativa entre os tratamentos com 0,5 e $10 \%$ de contaminação.

Nos resultados de rendimento de grãos obtidos no híbrido C 901, detectou-se redução de $7,6 \%$ correspondendo a $388 \mathrm{~kg} / \mathrm{ha}$ no tratamento com $20 \%$ de plantas contaminantes. Redução de $80 \%$ foi observado no tratamento com $100 \%$ de plantas contaminantes. Diferenças não foram observadas nos tratamentos com 0,5 e $10 \%$ de contaminação. Nos resultados de produção total obtidos em populações de plantas híbridas com $20 \%$ de contaminação, observaram-se menores reduções nos híbridos C 701 e C 901 (7,3 e 7,6\% respectivamente) e maiores nos híbridos C 808 A e C 425 (11,2 e $13,3 \%$ respectivamente), quando comparado ao tratamento com $0 \%$ de contaminação.

Os resultados de produção de grãos por planta híbrida apresentados na Figura 27, para os híbridos C 701 e C 901, explicam os resultados abordados acima. A produção por planta nos tratamentos com $20 \%$ de contaminação foi maior que nos tratamentos com 0,5 e $10 \%$, sendo que o mesmo não ocorreu para os híbridos C 425 e C 808 A. Isto significa que, os híbridos C 901 e C 701 apresentaram boa capacidade de compensação, 
diminuindo assim os riscos com a perda de produção, decorrente da mistura com sementes de plantas autofecundadas. A abordagem feita acima é válida para o tratamento com $20 \%$ de contaminação.

As equações de regressão para produção total de grãos para cada híbrido, em relação às taxas de contaminação encontram-se na Figura 34. Para a característica produção total de grãos, a regressão linear foi significativa para todos os híbridos. Os coeficientes de determinação $\left(R^{2}\right)$ que representam, em porcentagem, quanto da variação na resposta é explicada pela regressão, foi superior a $96 \%$ para todos os híbridos. De uma maneira geral, à medida em que foi aumentada a contaminação com plantas autofecundadas, houve redução do rendimento de grãos para todos os híbridos. A intensidade de redução variou com o híbrido estudado. Menor intensidade foi observada no híbrido C 808 A seguido pelos híbridos C 701 e C 425 e C 901. Estes resultados corroboram os obtidos por PINTÉR (1984) em que a redução no rendimento dos grãos por contaminação foi maior nos híbridos simples, do que nos duplos.

Comparando-se os resultados de produção do híbrido C 901 obtidos pela equação de regressão para valores de 0 a $100 \%$ de contaminação, com os do tratamento com $20 \%$ de contaminação (Figura 33), observou-se que apesar das plantas híbridas do híbrido C 901 apresentarem boa capacidade de compensação, a produção por planta contaminante foi baixa, reduzindo a produção total de grãos em lotes com alto porcentual de contaminação, e contribuindo com o aumento do valor de b da equação de regressão. 


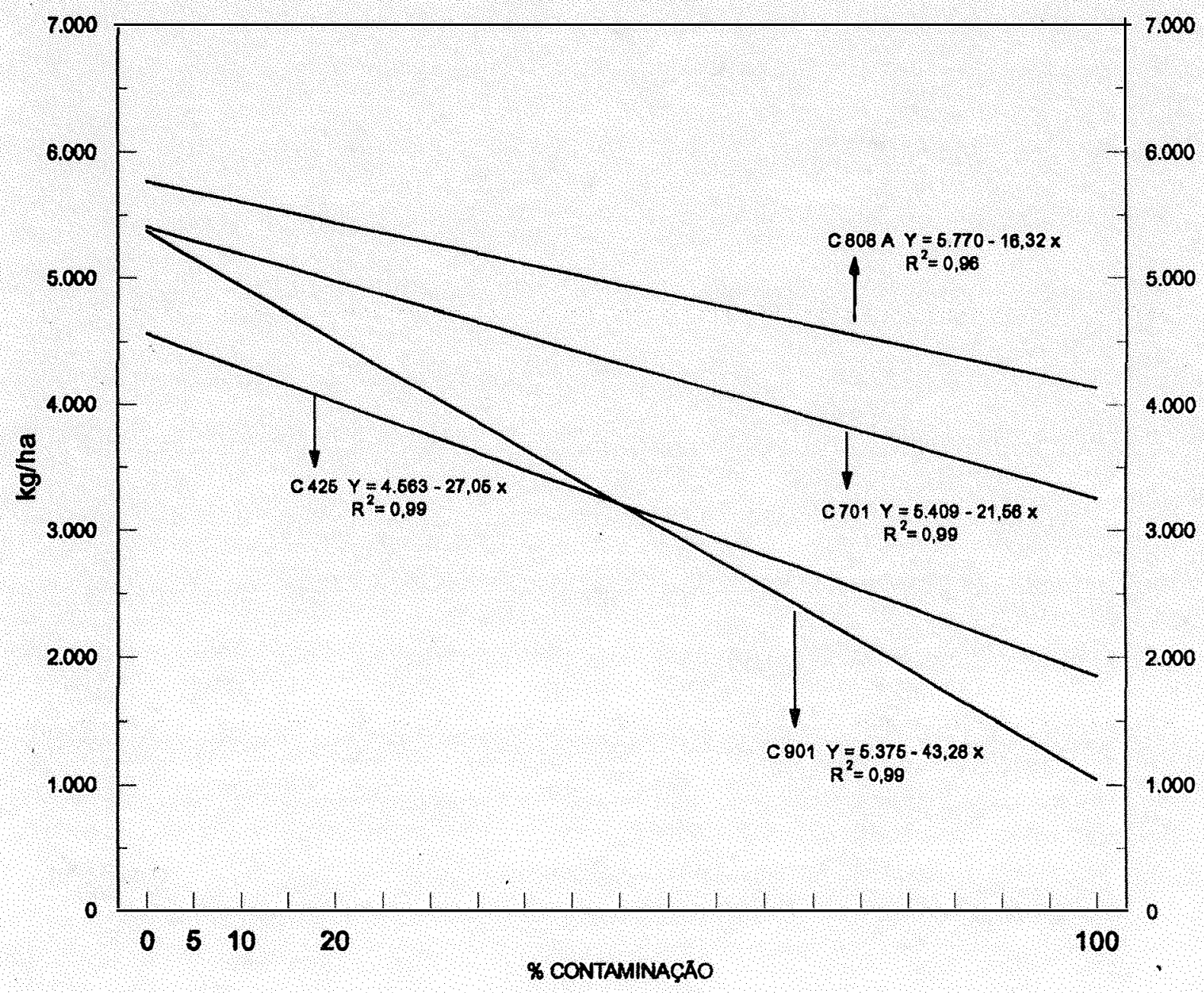

Figura 34. Representação gráfica das equações de regressão para os resultados de produção total de grãos $(\mathrm{kg} / \mathrm{ha})$, que expressam o efeito das taxas de contaminação dentro do fator hibridos. 
A redução observada para cada $1 \%$ de contaminação nos tratamentos com $20 \%$ de contaminação foi de $21 \mathrm{~kg} /$ ha (Figura 33 ).

O valor de b da equação de regressão para produção total de grãos do híbrido C 808 A foi menor $(16,32)$, comparado aos valores dos outros híbridos. Isto significa que, para cada $1 \%$ de contaminação houve redução de $16,32 \mathrm{~kg} / \mathrm{ha}$ de grãos. Nos resultados de produção total de grãos, obtidos no tratamento com $20 \%$ de contaminação (Figura 33), observou-se redução de $31 \mathrm{~kg} / \mathrm{ha}$ de grãos para cada $1 \%$ de contaminação, quando comparado ao tratamento com $0 \%$.

Os resultados observados para o híbrido C 808 A concordam com aqueles obtidos por PINTÉR (1984), em que o efeito de uma unidade de contaminação sobre o rendimento de grãos dos híbridos foi mais pronunciado sob baixas porcentagens de contaminação. Este comportamento não foi verificado para os híbridos C 901 , C 701 e C 425. A redução na produção de grãos dos dois últimos híbridos para cada unidade de contaminação foi relativamente constante nos tratamentos com diferentes taxas de contaminação.

Os resultados de produção de grãos por planta híbrida e planta contaminante do híbrido C 808 A foi maior, contribuindo com a redução do valor de b da equação de regressão. A proporção da produção entre planta híbrida ( $0 \%$ de contaminação) e planta contaminante (100\% de contaminação) do híbrido C 808 A foi de 1,49 , ao passo que para o híbrido C 901 foi de 4,1 (Figuras 33 e 34 ). 
PINTÉR (1984) afirmou em seu trabalho que a intensidade de redução no rendimento de grãos depende do rendimento das plantas provenientes de autofecundação, além da capacidade de compensação das plantas híbridas, o que foi confirmado no presente trabalho.

Na Figura 35, está apresentada a equação de regressão considerando a produção total de grãos na média dos quatro híbridos nos quatro locais estudados. Para cada $1 \%$ de contaminação com sementes provenientes do parental fêmea autofecundado ocorreu redução de $27 \mathrm{~kg} / \mathrm{ha}$, correspondendo à $0,5 \%$ da produção.

Se adotarmos um padrão de tolerância de $6 \%$ de sementes provenientes do parental fêmea autofecundado como é adotado em algumas empresas americanas, reduziríamos o rendimento em $162 \mathrm{~kg} / \mathrm{ha}$, considerando os quatro híbridos. Se considerarmos reduções referentes ao híbrido simples C 901, baseado na equação de regressão, a redução seria mais significativa. Neste caso, além da redução na produção de grãos, um aspecto de importância que deve ser considerado, é a exposição da linhagem em lavouras comerciais, decorrente de autofecundações em campos de produção de sementes. A exposição das linhagens poderá prejudicar o trabalho realizado durante vários anos pelos melhoristas.

Na Figura 36 estão apresentados os resultados de produção total de grãos, obtidos em diferentes locais, para os tratamentos com diferentes taxas de contaminação. 


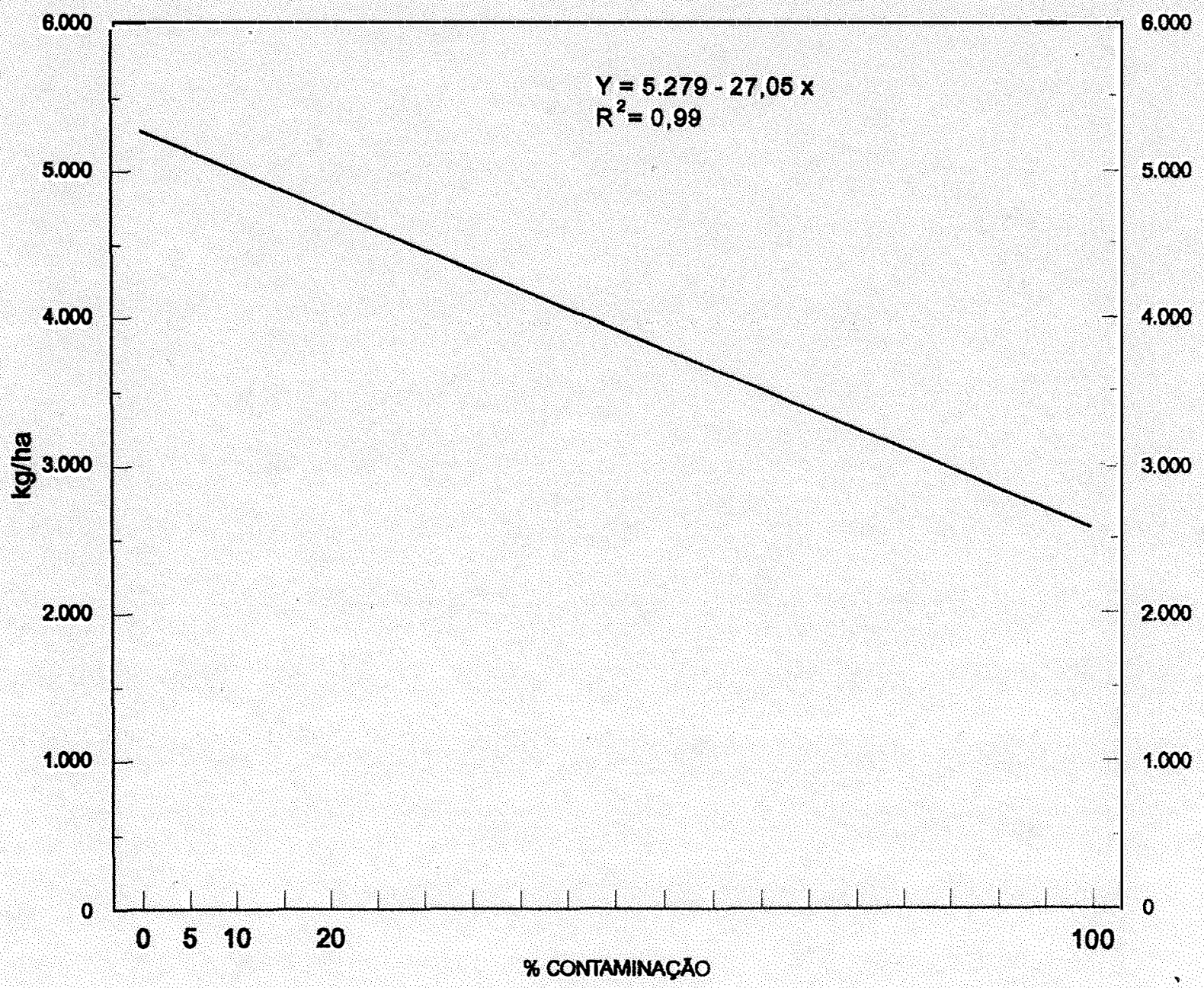

Figura 35. Representação gráfica da equação de regressão para os resultados de produção total de grãos $(\mathrm{kg} / \mathrm{ha})$, que expressam o efeito médio das taxas de contaminação dentro dos fatores hibridos e locais. 
Figura 36. Resultados médios de produção total de grãos (kg/ha) obtidos sob diferentes taxas de contaminação em diferentes locais.

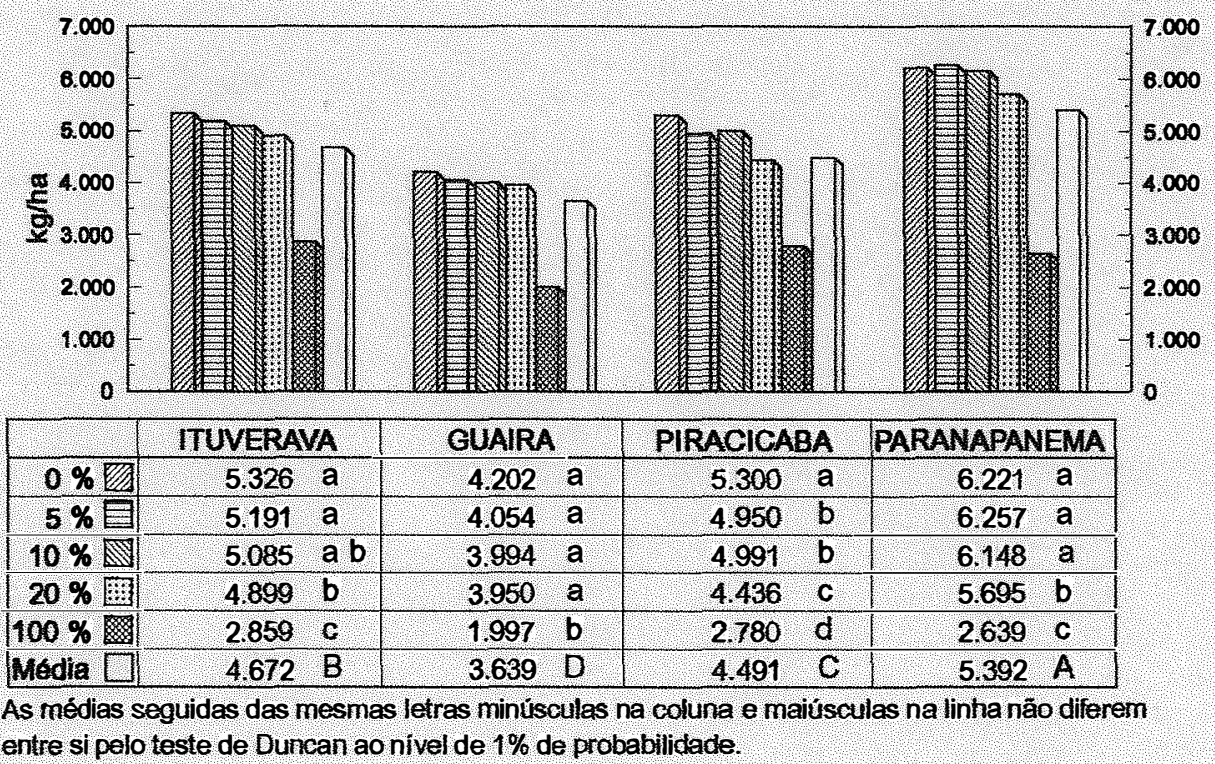

Em Ituverava, taxas de contaminação de 0,5 e $10 \%$ não apresentaram diferença significativa entre si para a produção total de grãos; o tratamento com $20 \%$ de contaminação apresentou redução de $8 \%$, correspondendo a $427 \mathrm{~kg} / \mathrm{ha}$, em relação ao tratamento com $0 \%$ de contaminação.

Resultados de produção total de grãos obtidos em Guaíra não apresentaram diferença significativa entre os tratamentos com 0,5 e 10 e $20 \%$ de contaminação. Entretanto, em Piracicaba, populações de plantas híbridas com $5 \%$ de plantas provenientes de autofecundação apresentaram redução na produção de grãos de $350 \mathrm{~kg} / \mathrm{ha}$, não diferindo estatisticamente do tratamento com $10 \%$ de contaminação. Redução na produção de grãos de $16,3 \%$ foi 
verificado neste local, quando $20 \%$ de plantas provenientes de autofecundação estavam presentes na população híbrida, que correspondeu a $864 \mathrm{~kg} / \mathrm{ha}$. Em Paranapanema este valor foi de $526 \mathrm{~kg} / \mathrm{ha}$ que correspondeu à redução de $8,4 \%$. Em todos os locais a redução foi maior em tratamentos com $100 \%$ de contaminação, variando em 54, 86, 84 e $86 \%$ em Ituverava, Guaíra, Piracicaba e Paranapanema, respectivamente.

As equações de regressão correspondentes à produção total de grãos, em relação às taxas de contaminação nos quatro locais, encontram-se na Figura 37; houve redução no rendimento de grãos à medida que se aumentou o taxa de contaminação. Os valores de $b$ da equação foram semelhantes em Guaíra, Ituverava e Piracicaba. Maior valor de b foi observado em Paranapanema $(37,4 \mathrm{~kg} / \mathrm{ha})$, o que, provavelmente tenha ocorrido, devido a maior proporção entre o valor de produção de grãos por planta híbrida e por planta proveniente de autofecundação (Figura 29).

Na Figura 38, estão apresentados os resultados de produção total de grãos dos híbridos em diferentes locais. Em Guaíra e Ituverava, o híbrido C 808 A apresentou-se mais produtivo, seguido pelos híbridos C 701, C 901 e C 425. Em Piracicaba e Paranapanema, representando a semeadura em época normal, maiores rendimentos foram observados nos híbridos C 808 A e C 701 e menores nos híbridos C 901 e C 425. 


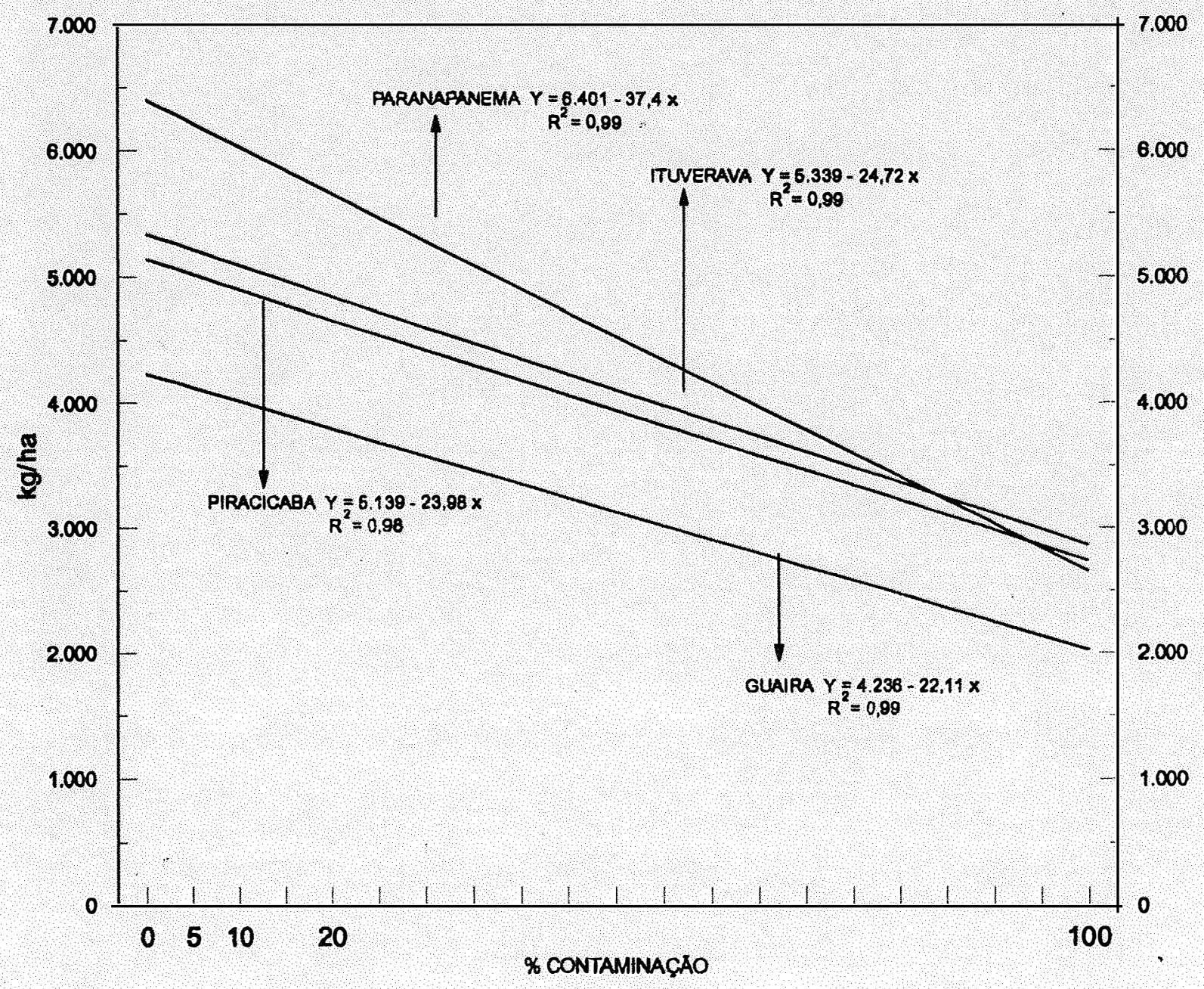

Figura 37. Representação gráfica das equações de regressão para os resultados de produção total de grãos ( $\mathrm{kg} / \mathrm{ha})$, que expressam o efeito das taxas de contaminação dentro do fator locais. 
Figura 38. Resultados médios de produção total de grãos (kg/ha) obtidos de diferentes híbridos de milho em diferentes locais.

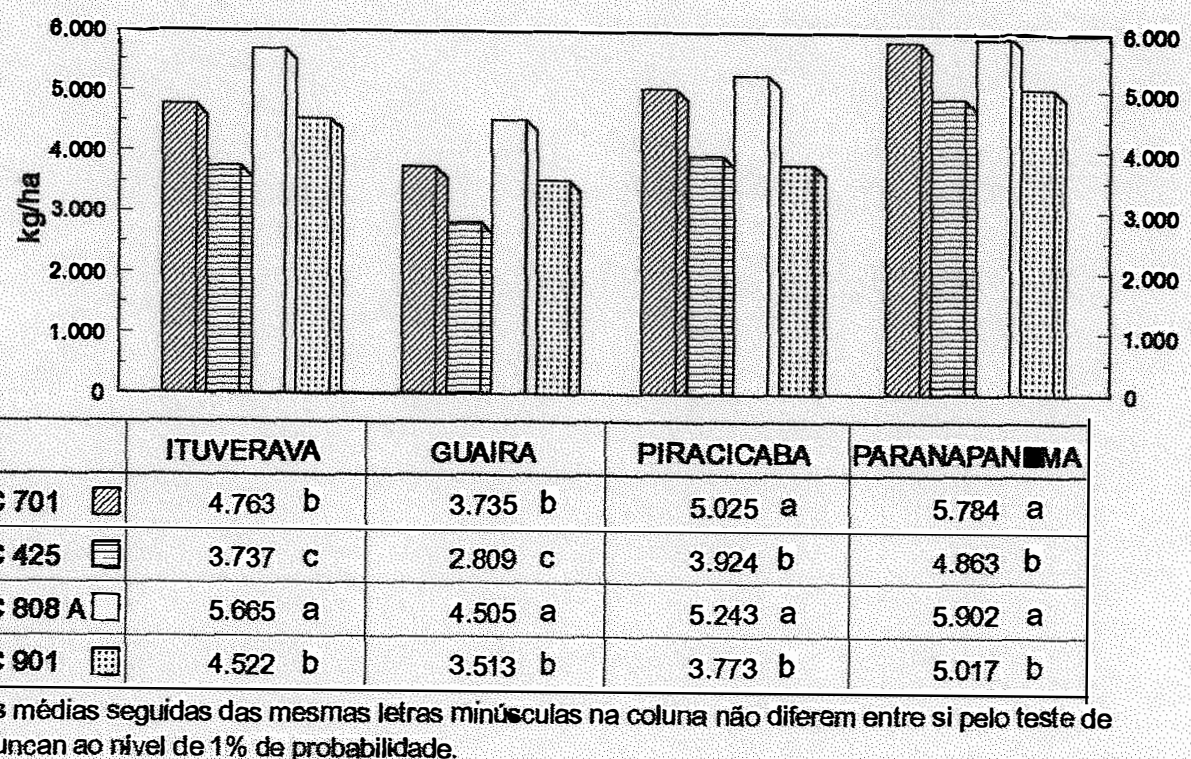

Duncan ao nivel de $1 \%$ de probabilidade.

O híbrido triplo C 808 A mostrou-se mais produtivo nos quatro locais, apresentando estabilidade de produção inclusive no cultivo de safrinha. Maiores rendimentos de grãos foram observados em Paranapanema, seguidos por Ituverava, Piracicaba e Guaíra. Em Paranapanema ocorreram maiores precipitações por decêndio (Figura 6), e com a utilização da irrigação, não houve déficit hídrico durante os estádios de desenvolvimento. Em Piracicaba, ocorreu pouca precipitação após a semeadura (Figura 5), o que retardou a emergência das plantas. Durante todo o ciclo da cultura houve má distribuição de chuvas, inclusive no florescimento e na fase de enchimento dos grãos, comprometendo assim, a produção de grãos.

No cultivo de safrinha, maior produção foi observada em Ituverava do que em Guaíra. Fatores como a precipitação e temperatura mínima podem explicar em parte estes resultados. Durante os estádios de florescimento 
e enchimento de grãos (maio e junho), ocorreu maior precipitação em Ituverava (Figura 1) do que em Guaíra (Figura 2). Em Guaíra as temperaturas mínimas ocorridas durante os meses de maio, junho e julho (Figura 4), foram mais baixas que aquelas predominantes em Ituverava (Figura 3); entretanto, os resultados obtidos neste trabalho, no cultivo de safrinha, indicam a viabilidade de plantio nesta época, apesar da baixa tecnologia empregada.

Os resultados médios de plantas híbridas, quebradas e acamadas apresentados na Figura 39, no híbrido C 425, indicaram diferenças significativas entre os tratamentos, onde menor índice foi observado no tratamento com $20 \%$ de contaminação. Plantas provenientes de autofecundação ( $100 \%$ de contaminação), apresentaram maior índice de quebramento e acamamento quando comparado às plantas híbridas. Durante as avaliações das plantas no campo, observou-se que, aquelas provenientes do parental fêmea autofecundado, apresentavam-se menos vigorosas e com menor espessura do colmo, quando comparado às plantas híbridas. Provavelmente a menor espessura do colmo tenha proporcionado menor tolerância ao quebramento e acamamento.

$\mathrm{Na}$ Figura 40, estão apresentados os resultados médios de plantas quebradas e acamadas provenientes de plantas do parental fêmea autofecundado. Plantas dos híbridos C 701, C 425 e C 901 ( $0 \%$ de contaminação) apresentaram menor índice de quebramento e acamamento que aquelas provenientes de autofecundação, nos tratamentos com 5, 10 e $20 \%$ de contaminação; entretanto, os resultados de quebramento e acamamento em 
plantas híbridas ( $0 \%$ de contaminação), não apresentaram diferenças daqueles obtidos em plantas provenientes de autofecundação ( $100 \%$ de contaminação).

Estes resultados mostraram que, plantas provenientes do parental fêmea autofecundado, quando estão presentes, em menores taxas dentro de populações de plantas híbridas, apresentam-se menos vigorosas, uma vez que, são dominadas pelas plantas híbridas, ficando assim, mais predispostas ao quebramento e acamamento. Na ausência de plantas híbridas (100\% de contaminação), plantas provenientes de autofecundação apresentaram-se mais vigorosas, reduzindo o porcentual de plantas quebradas e acamadas.

Os resultados de plantas quebradas e acamadas dos híbridos nos diferentes locais estão apresentados na Figura 41.

Figura 39. Resultados médios de plantas híbridas quebradas e acamadas (\%) em populações com diferentes taxas de contaminação com plantas autofecundadas.

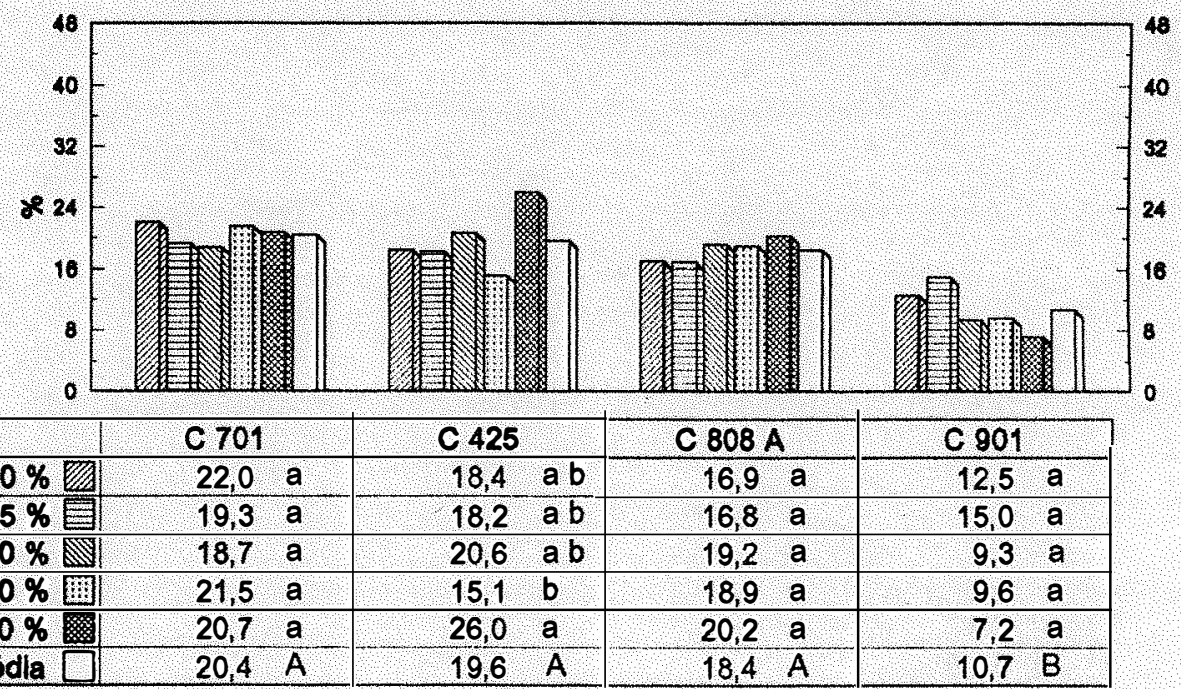

As médias seguidas das mesmas letras minúsculas na coluna e maiúsculas na linha nâo diferem entre si pelo teste de Duncan ao nivel de $1 \%$ de probabilidade. 
Figura 40. Resultados médios de plantas autofecundadas quebradas e acamadas (\%), atuando como contaminante, em diferentes taxas, em populações de plantas híbridas.

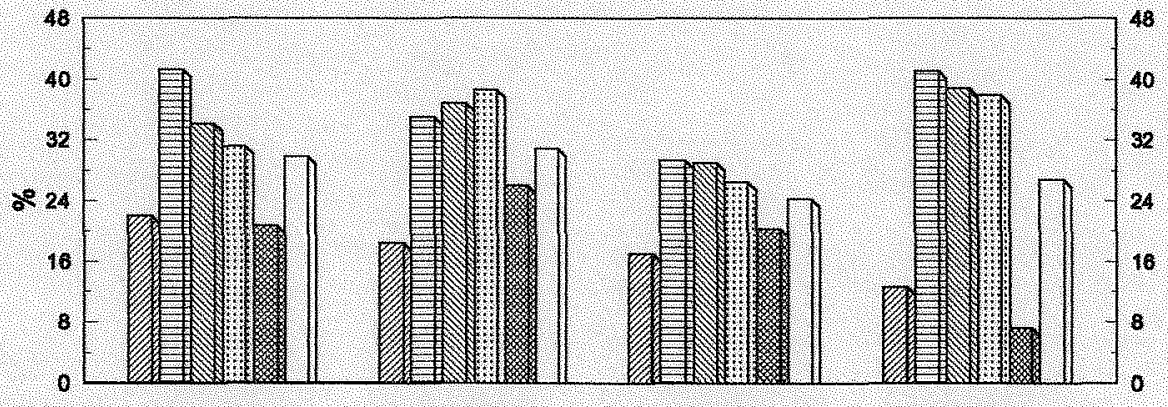

\begin{tabular}{|c|c|c|c|c|c|c|c|c|}
\hline & \multicolumn{2}{|l|}{ C 701} & \multicolumn{2}{|c|}{ C 425} & \multicolumn{2}{|l|}{ C $808 \mathrm{~A}$} & \multicolumn{2}{|l|}{ C 901} \\
\hline $0 \%$ & 22,0 & b & 18,4 & b & 16,9 & a & 12,5 & b \\
\hline $5 \%$ 国 & 41,3 & a & 35,0 & a & 29,3 & a & 41,0 & a \\
\hline $10 \%$ & 34,1 & $a b$ & 36,8 & a & 28,9 & a & 38,7 & a \\
\hline $20 \%$ 雷 & 31,1 & $a b$ & 38,5 & a & 26,4 & a & 37,8 & a \\
\hline $100 \%$ & 20,7 & b & 26,0 & $a b$ & 20,2 & a & 7,2 & b \\
\hline Médla & 29,8 & A B & 30,8 & A & 24,2 & B & 26,8 & $A B$ \\
\hline
\end{tabular}

As médias seguidas das mesmas letras minúsculas na coluna e maiúsculas na linha não diierem entre si pelo teste de Duncan ao nivel de $1 \%$ de probabilidade.

Figura 41 . Resultados médios de plantas híbridas quebradas e acamadas (\%) de diferentes híbridos de milho em diferentes locais.

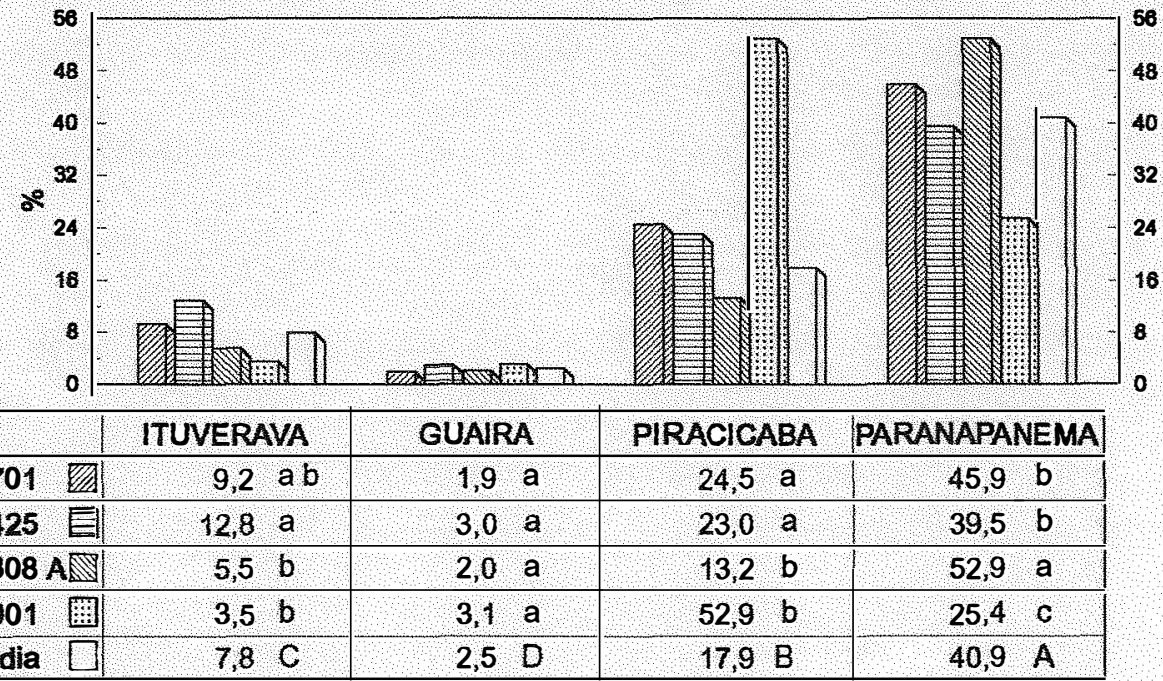

As médias seguidas das mesmas letras minúsculas na coluna e maiúsculas na linha não diferem entre si pelo teste de Duncan ao nivel de $1 \%$ de probabilidade. 
Os híbridos apresentaram comportamento variável quanto a porcentagem de plantas híbridas quebradas e acamadas nos diferentes locais. Variações para esta característica, também foram observadas para plantas provenientes de autofecundação nos diferentes locais (Figura 42). Em Ituverava e Guaíra, não houve diferença quanto à porcentagem de plantas quebradas e acamadas. Em Piracicaba, menor índice foi observado para o híbrido C 808 A e em Paranapanema para o híbrido C 901. De uma maneira geral, foi observado maior porcentagem de plantas quebradas e acamadas em Paranapanema e Piracicaba. Estes resultados ocorreram devido à uma tempestade, com vento, observada no final do ciclo da cultura nos dois locais.

Como indicado no resumo da análise de variância na Tabela 8 , a interação taxas de contaminação $\mathrm{x}$ locais, para plantas híbridas quebradas e acamadas, não foi significativa. Os resultados dessa interação estão apresentados na Figura 43.

Os resultados de plantas quebradas e acamadas, obtidos do parental fêmea autofecundado variaram nos locais com as diferentes taxas de contaminação (Figura 44). Em Ituverava, Piracicaba e Paranapanema, menores índices de plantas quebradas e acamadas foram observadas nos tratamentos com 0 e $100 \%$ de contaminação.

Em Guaíra, apesar de não ter sido observado diferença significativa entre os tratamentos com $0,5,10,20$ e $100 \%$ de contaminação, menores valores de plantas quebradas e acamadas foram verificadas nos tratamentos com 0 e $100 \%$ de contaminação. 
Figura 42. Resultados médios de plantas quebradas e acamadas (\%), provenientes do parental fêmea autofecudado de diferentes hibridos de milho em diferentes locais.

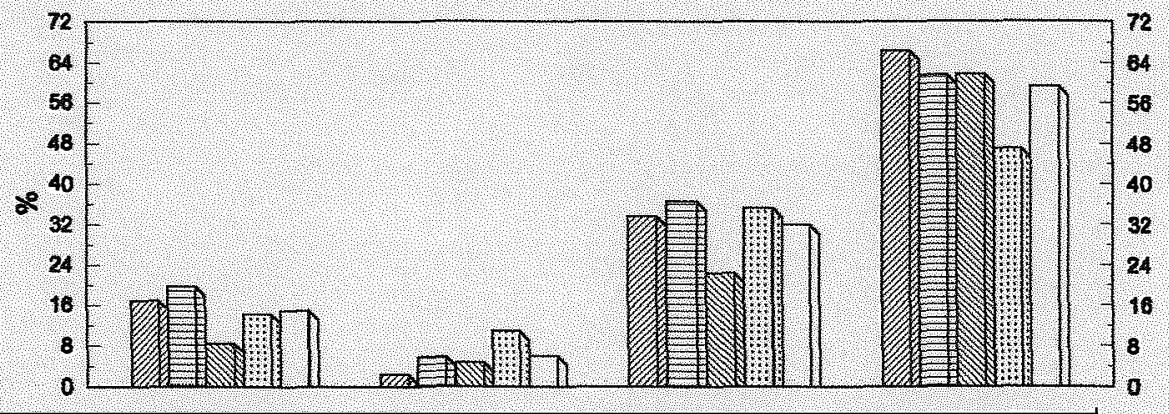

\begin{tabular}{|c|c|c|c|c|}
\hline & ITUVERAVA & GUAIRA & PIRACICABA & PARANAPANEMA \\
\hline C 701 V & $16,9, a$ & $2,3 \quad a$ & 33,6 a b & 66,3 a \\
\hline C 425 目 & 19,6 a & 5,8 a & 36,5 a & 61,5 a \\
\hline C $808 \mathrm{AM}$ & 8,5 a & 4,6 a & 22,3 , b & 61,6 a \\
\hline C 901. [.] & 14,3 a & 10,9 a & 35,2 a & $46,9, \mathrm{~b}$ \\
\hline Média प] & $14,9, \mathrm{C}$ & $5,9, \mathrm{D}$ & 31,9 B & 59,1 A \\
\hline
\end{tabular}

As médias seguidas das mesmas letras minúsculas na coluna e maiúsculas na linha não diferem entre si pelo teste de Duncan ao nivel de $1 \%$ de probabilidade.

Figura 43. Resultados médios de plantas híbridas quebradas e acamadas (\%), em populações com diferentes taxas de contaminação com plantas provenientes de autofecundação em diferentes locais.

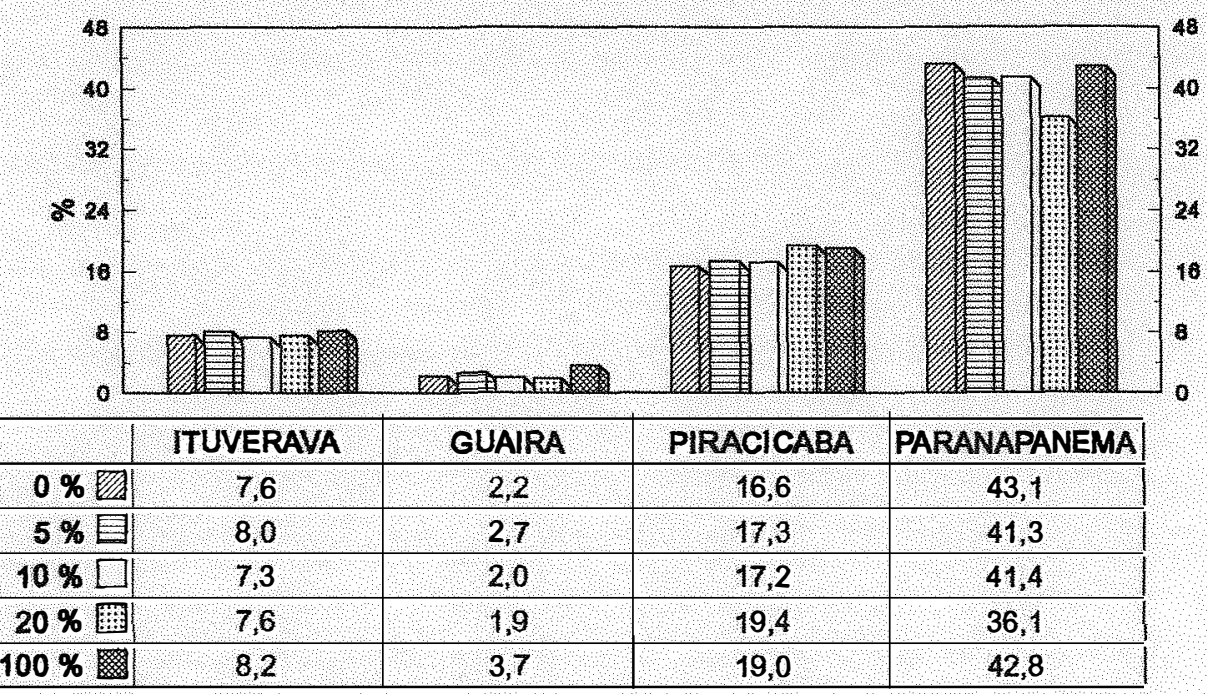

As médias seguidas das mesmas letras minúsculas na coluna não diterem entre si pelo teste de Duncan ao nivel de $1 \%$ de probabilidade. 
Figura 44. Resultados médios de plantas autofecundadas quebradas $e$ acamadas, atuando como contaminante, em diferentes taxas, em populações de plantas híbridas em diferentes locais.

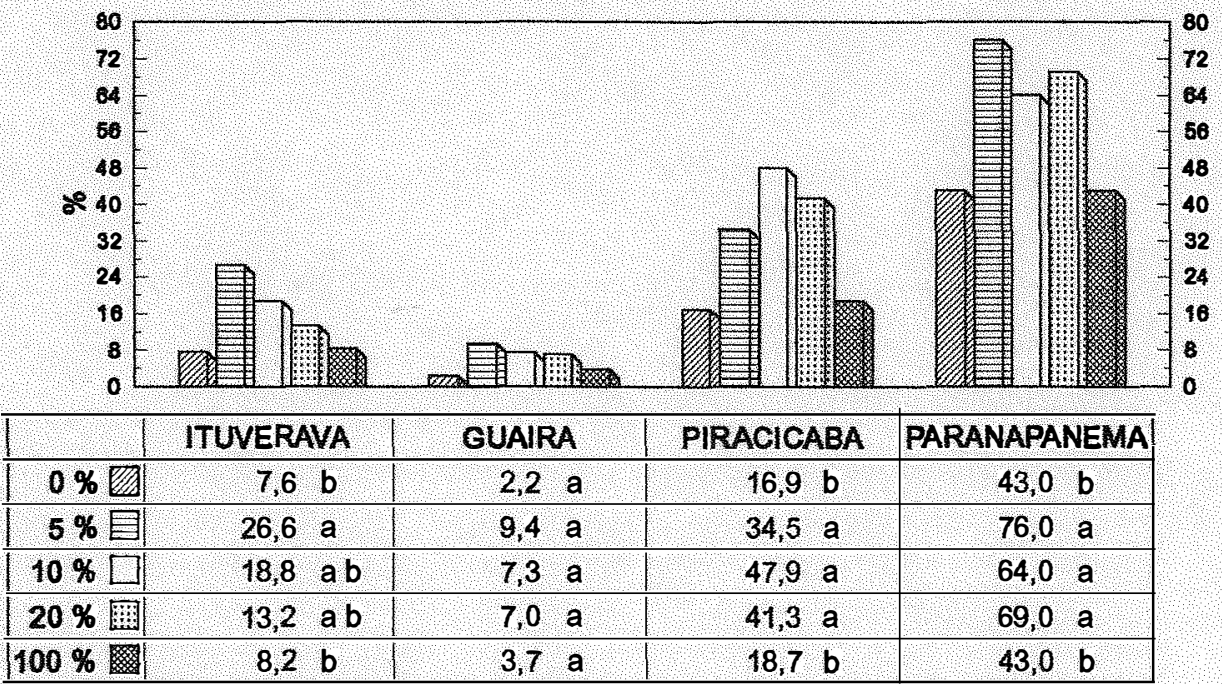

As médias seguidas das mesmas letras minúsculas na coluna não diferem entre si pelo teste de Duncan ao nivel de $1 \%$ de probabilidade.

A ausência de trabalhos referentes ao porcentual de plantas quebradas e acamadas nas condições do presente trabalho, dificultou a discussão dos resultados obtidos. Entretanto, no trabalho desenvolvido por CAPELARO (1992), houve aumento no número de plantas acamadas à medida que aumentou-se o número de plantas não despendoadas no campo de produção de sementes.

A não realização do despendoamento ou o despendoamento mal conduzido, pode proporcionar a ocorrência de autofecundação, cujas sementes podem dar origem a plantas menos vigorosas devido a depressão por endogamia, ficando mais sujeitas ao quebramento e acamamento. Por outro lado, plantas híbridas por serem mais vigorosas e por apresentarem geralmente maiores diâmetros de colmo, estão menos sujeitas ao quebramento e acamamento. Outro aspecto que deve ser levado em consideração é que, altos 
índices de plantas quebradas e acamadas em lavouras de milho, podem inviabilizar a colheita mecânica.

\subsection{Avaliação da Pureza Genética}

A metodologia utilizada para a identificação de sementes provenientes do parental fêmea autofecundado, empregando a coloração do endosperma com solução de iodo, não foi eficiente.

A viabilidade de utilização desta técnica foi observada por JUGENHEIMER (1958). O autor atribuiu as diferenças de coloração do endosperma às variações no teor de amido entre as sementes. Provavelmente, a diferença no teor de amido, entre as sementes híbridas e as provenientes do parental fêmea autofecundado dos híbridos estudados no presente trabalho, não tenha sido suficientemente acentuada para permitir a separação.

Na Tabela 9, estão apresentados os resultados médios, dos porcentuais de acerto e erro, obtidos nas identificações de plantas provenientes do parental fêmea autofecundado.

No hibrido C 701, maior porcentagem de acerto e menor porcentagem de erro foi observada durante a avaliação das espigas em pós colheita. A principal característica utilizada para separação foi a cor do grão. Espigas das plantas contaminantes apresentavam grãos com coloração laranja escura. Enquanto, os das híbridas, apresentavam-se com tons laranja mais claros (Figura 1a). Esta mesma característica foi adotada durante a colheita, onde as espigas foram avaliadas nas plantas, com índice de acerto de $92,3 \%$. A 
avaliação das espigas em pós colheita foi feita à sombra, o que pode ter facilitado a avaliação da cor em relação à realizada na planta que reuniria a incidência de raios solares.

Tabela 9. Resultados de identificação (\% de acerto e \% erro) de plantas provenientes do parental fêmea autofecundado de diferentes híbridos em várias épocas de avaliação.

\begin{tabular}{llrrrrr}
\hline & & \multicolumn{5}{c}{ Épocas de Avaliação } \\
\cline { 3 - 7 } Hibrido & & Plântula & $5-7$ folhas & Florescimento & Colheita & Pós-Colheita \\
\hline C 701 & \% acerto & $90,0 \pm 4,1 *$ & $84,7 \pm 5,1$ & $93,8 \pm 2,5$ & $92,3 \pm 1,7$ & $97,1 \pm 2,5$ \\
& $\%$ erro & $7,5 \pm 1,0$ & $8,5 \pm 3,1$ & $3,6 \pm 0,5$ & $2,6 \pm 0,5$ & $1,1 \pm 0,6$ \\
\hline C 425 & \% acerto & $37,5 \pm 2,5$ & $67,8 \pm 7,0$ & $58,3 \pm 6,6$ & $63,1 \pm 5,1$ & $58,8 \pm 7,4$ \\
& \% erro & $30,0 \pm 4,7$ & $17,9 \pm 3,1$ & $22,1 \pm 1,6$ & $12,1 \pm 1,5$ & $17,2 \pm 2,1$ \\
\hline C 808 A \% acerto & $95,0 \pm 2,9$ & $84,6 \pm 5,9$ & $96,8 \pm 2,0$ & $92,6 \pm 2,0$ & $97,9 \pm 2,5$ \\
& $\%$ erro & $3,1 \pm 1,1$ & $8,6 \pm 2,9$ & $1,1 \pm 0,4$ & $3,3 \pm 1,4$ & $0,8 \pm 0,5$ \\
\hline C 901 & $\%$ acerto & $95,0 \pm 2,9$ & $98,5 \pm 1,2$ & $98,3 \pm 0,6$ & $98,2 \pm 2,3$ & $81,7 \pm 5,4$ \\
& $\%$ erro & $1,2 \pm 0,7$ & $1,7 \pm 0,4$ & $0,6 \pm 0,1$ & $0,6 \pm 0,6$ & $6,4 \pm 1,0$ \\
\hline
\end{tabular}

*-Desvio padrão da média

$\mathrm{Na}$ avaliação durante o florescimento houve acerto de $93,8 \%$ das plantas contaminantes. A principal característica utilizada para a separação das plantas foi a pigmentação das anteras. Anteras de plantas contaminantes mostravam-se com coloração violeta devido à presença de antocianina, ao passo que as plantas híbridas mostravam-se verdes, como o indicado na Figura 2a.

Durante a avaliação, algumas plantas contaminantes apresentavam anteras com coloração verde; no entanto, na conexão das glumas, que envolvem os estames havia anel com coloração avermelhada, ausente nas 
plantas híbridas (Figura 3a). Este anel foi citado por PAUKSENS \& DHESI (1978) como sendo um marcador adequado para a identificação de híbridos.

No estádio de 5-7 folhas não foi observada nenhuma característica específica que permitisse separar plantas híbridas das contaminantes. Esta avaliação considerou o vigor das plantas. Geralmente, as plantas contaminantes mostravam-se menos vigorosas, quando comparadas às híbridas. A avaliação nesse estádio foi a menos eficiente, com índice de acerto de $84,7 \%$ e de erro de $8,5 \%$.

O vigor das plantas neste estádio, considerando a altura da planta e a espessura do colmo, pode variar com a fertilidade do solo, estande e outros fatores, influenciando na precisão da avaliação.

A avaliação no estádio de plântula foi mais eficiente do que no estádio de 5-7 folhas, com índice de acerto de $90 \%$. Neste estádio, a principal característica utilizada foi a intensidade da pigmentação de antocianina na bainha da primeira folha. Plântulas, provenientes de autofecundação, apresentavam a bainha da primeira folha com cor púrpura acentuada, principalmente nas partes mediana e superior, como mostrado na Figura 4a; essa cor, na maioria das vezes, se estendia à nervura central da primeira folha. A bainha da primeira folha da plântula híbrida apresentava-se com tom rosado, mais claro que o descrito para as plantas provenientes de autofecundação; a nervura central da primeira folha, geralmente apresentava-se com coloração esverdeada.

Quanto aos resultados encontrados nas avaliações das plantas no híbrido C 425 , a fase que proporcionou maior porcentagem de acerto foi a 
de colheita com $63,1 \%$. Em todas as épocas de avaliação, não foi observada nenhuma característica que permitisse separação precisa entre os dois tipos de planta. No estádio de plântula, a bainha da primeira folha das plantas contaminantes apresentava-se arroxeada como esverdeada, dificultando a adoção de um padrão para avaliação.

No estádio de 5-7 folhas, a avaliação foi feita observando a altura da planta e a espessura do colmo. No florescimento, características observadas nas flores masculinas e femininas não permitiram a diferenciação entre plantas híbridas e plantas contaminantes; nesse estádio, a avaliação também foi baseada no vigor das plantas, principalmente considerando espessura do colmo.

Durante as avaliações das espigas em colheita e pós colheita, procurou-se separar os materiais quanto ao tipo e cor dos grãos. Entretanto, foram observadas variações do tipo de grãos entre as plantas contaminantes. Algumas espigas mostravam grãos com endosperma mole do tipo dentado e, outras, grãos com endosperma duro (Figura 5a).

Quanto ao híbrido C 808 A, maiores porcentagens de acerto foram observadas, nas avaliações realizadas em espigas em pós colheita, florescimento e estádio de plântula. No estádio de plântula, a cor da bainha da primeira folha foi a principal característica utilizada; plântulas híbridas apresentavam a bainha da primeira folha com coloração esverdeada ou púrpura em tons claros; plântulas provenientes do parental fêmea autofecundado, apresentavam a bainha da primeira folha com coloração púrpura intensa como o indicado a Figura 6a. Outra característica utilizada, para a identificação das 
plântulas, foi o vigor; geralmente, as plântulas híbridas apresentavam três folhas expostas e desenroladas, ao passo que as plântulas contaminantes apresentavam duas folhas expostas. Quando ocorriam dúvidas, quanto à coloração da bainha da primeira folha, esta característica auxiliava na identificação das plântulas.

A menor porcentagem de acerto foi verificada, nas avaliações realizadas em plântulas com $5-7$ folhas $(84,6 \%)$, onde foi observado maior índice de erro $(8,6 \%)$; neste estádio, o vigor das plantas foi a característica utilizada. No florescimento, características das flores femininas foram empregadas na diferenciação. Plantas provenientes de autofecundação apresentavam estilo-estigmas com coloração vermelha intensa, enquanto os das plantas híbridas apresentavam coloração esverdeada ou rosada, como o indicado na Figura 7a. Outra característica, utilizada nesse estádio foi a data de florescimento das plantas femininas; plantas híbridas floresciam três a quatro dias antes das plantas contaminantes.

Nas avaliações realizadas nas espigas, em colheita e pós colheita, o tipo de grão foi a característica utilizada para a separação dos materiais. Espigas de plantas híbridas apresentavam grãos do tipo dentado, enquanto os das plantas contaminantes apresentavam grãos duro como o indicado na Figura 8a.

Para o híbrido C 901, as avaliações realizadas foram eficientes na separação, com excę̧ão da realizada em espigas em pós colheita. No estádio de plântulas a característica utilizada foi a coloração entre as nervuras do coleoptilo. Plântulas híbridas apresentavam coleoptilo com coloração arroxeada 
enquanto as contaminantes o apresentavam com coloração esverdeada, como indicado na Figura 9a. Para facilitar a avaliação, os coleóptilos foram removidos das plântulas, objetivando evitar que a coloração do mesocótilo pudesse interferir na identificação.

No estádio de plântula, a avaliação apresentou índice de acerto de $98,5 \%$, superior aos nesse estádio para os híbridos C 808 A, C 701 e C 425. A principal característica utilizada foi o vigor das plântulas. Por tratarse de um híbrido simples, as plantas provenientes de sementes oriundas do parental fêmea autofecundado eram linhagens que, em geral, são pouco vigorosas, o que facilitou a sua separação das demais. As plantas contaminantes apresentavam-se com menores altura e diâmetro do colmo. A diferença de vigor, entre plantas híbridas e contaminantes, persistiu durante o ciclo da cultura, facilitando as avaliações subseqüentes. No florescimento, as plantas contaminantes apresentavam estilo-estigmas com coloração esverdeada ou rósea clara, enquanto as plantas híbridas apresentavam estílo-estigmas com coloração avermelhada. O florescimento feminino, das plantas híbridas, foi mais precoce do que o das plantas contaminantes.

A avaliação na fase de colheita foi realizada considerando o vigor das plantas, uma vez que os grãos das plantas eram, invariavelmente, dentados (Figura 10a). Houve diferença entre o tamanho das primeiras espigas das plantas híbridas e contaminantes. No entanto, quando as plantas híbridas apresentavam a segunda, muita das vezes esta não se diferenciava da espiga da linhagem. Isso, provavelmente, tenha contribuído para a redução do acerto na avaliação em espigas $(81,7 \%)$. Este resultado mostrou que a avaliação das 
plantas pode ser, além da de espigas, importante para a identificação de plantas em final de ciclo.

A avaliação, nesse híbrido, foi mais eficiente na colheita, do que em pós colheita, ocasião em que características da planta, como o vigor, não foram avaliadas.

Em um programa de controle de qualidade, na produção de sementes de milho, é mais interessante a identificação de contaminantes no estádio de plântulas por permitir a análise da pureza genética após a colheita e anteriormente à comercialização das sementes. No entanto, a avaliação em estádios mais avançados permite a aferição do trabalho de despendoamento nos campos de produção, que, inclusive, pode orientar alterações metodológicas em safras subseqüentes.

Principalmente nos híbridos C 808 A e C 901, a avaliação da pureza genética, no estádio de plântula, mostrou-se relativamente precisa.

Características selecionadas, na presente pesquisa, para a identificação de plantas, tais como as cores dos estilo-estigmas, da antera e do grão foram apontadas por SMITH \& SMITH (1989) como sendo de alta repetibilidade em vários locais e anos. Dessa maneira, parece válida a utilização dessas características como descritores de genótipos de milho.

Apesar de alguns autores terem enfatizado a ocorrência de variações na pigmentação em várias partes das plantas, dificultando a identificação de cultivares de milho (SRIVASTAVA \& AGRAWAL, 1985; STYLES, 1993), os resultados obtidos na presente pesquisa mostraram-se promissores principalmente nos híbridos C 901 e C 808 A. A possibilidade de 
utilização de características morfológicas para a avaliação da pureza genética, deve ser estudada para cada híbrido. Como foi abordado por SMITH \& SMITH (1987), a variabilidade em cada população híbrida, depende, sobretudo, da diferença genética entre as linhas parentais.

SMITH \& WYCK (1988), fizeram comparações entre os usos da eletroforese e das características morfológicas de plantas para estimar a contaminação de sementes provenientes do parental fêmea autofecundado em lotes de sementes híbridas de milho. Os autores basearam-se, principalmente, na estimativa do vigor das plantas nos estádios de 5-7 folhas e na antese. Na presente pesquisa, no florescimento a observação da coloração das flores masculinas e femininas foi mais interessante que a observação do vigor de plantas.

Ainda sobre o trabalho de SMITH \& WYCK (1988), vale ressaltar que não foi computada a taxa erro ocorrida durante as avaliações. Assim, plantas hibridas podem ter sido computadas como contaminantes, uma vez que não houve os controles de posição e do número de plantas contaminantes nas parcelas experimentais.

Na Tabela 10 estão apresentados os resultados do teste de quiquadrado, utilizado para verificar a significância dos desvios entre os resultados obtidos pelos três avaliadores.

Nos híbridos, C 701 e C 808 A, apenas o resultado dos desvios observados no estádio de 5-7 folhas foi significativo. Os desvios observados nos demais estádios, não significativos, indicaram que os erros foram devidos ao acaso (erro amostral). 
Tabela 10. Resultados do teste de qui-quadrado $\left(\lambda^{2}\right)$ aplicados aos dados de identificação de plantas provenientes do parental fêmea autofecundado de diferentes híbridos, em várias épocas de avaliação, obtidos por três avaliadores.

\section{Epocas de Avaliação}

Híbrido Avaliador Plântula 5-7 folhas Florescimento Colheita Pós-Colheita

\begin{tabular}{llccccc}
\hline \multirow{3}{*}{ C 701 } & 1 & 0,10 & 3,11 & 0,69 & 1,03 & 0,11 \\
& 2 & 0,40 & 2,79 & 0,08 & 1,03 & 0,11 \\
& 3 & 0,00 & 2,49 & 0,05 & 0,21 & 0,01 \\
\cline { 2 - 7 } & $\lambda^{2}$ & $0,50 \mathrm{NS}$ & $8,39 *$ & $0,82 \mathrm{NS}$ & $2,27 \mathrm{NS}$ & $0,23 \mathrm{NS}$ \\
\hline \multirow{3}{*}{ C 425 } & 1 & 3,60 & 14,49 & 19,21 & 13,23 & 16,20 \\
& 2 & 4,90 & 13,21 & 13,11 & 15,21 & 12,01 \\
& 3 & 4,60 & 13,79 & 30,01 & 19,04 & 12,80 \\
\cline { 2 - 7 } & $\lambda^{2}$ & $13,10 * *$ & $41,49 * *$ & $62,33^{* *}$ & $47,48^{* *}$ & $41,01 * *$ \\
\hline \multirow{3}{*}{ C 808 A } & 1 & 0,00 & 2,45 & 0,03 & 0,69 & 0,01 \\
& 2 & 0,00 & 4,10 & 0,21 & 0,14 & 0,11 \\
& 3 & 0,10 & 1,91 & 0,54 & 1,43 & 0,01 \\
\cline { 2 - 8 } & $\lambda^{2}$ & $0,10 \mathrm{NS}$ & $8,46 *$ & $0,78 \mathrm{NS}$ & $2,26 \mathrm{NS}$ & $0,13 \mathrm{NS}$ \\
\hline \multirow{3}{*}{ C 901 } & 1 & 0,00 & 0,03 & 0,08 & 0,08 & 1,51 \\
& 2 & 0,00 & 0,03 & 0,00 & 0,03 & 6,61 \\
& 3 & 0,10 & 0,01 & 0,08 & 0,01 & 1,25 \\
\hline
\end{tabular}

** - Significativo ao nível de $1 \%$ de probabilidade.

* - Significativo ao nivel de $5 \%$ de probabilidade.

NS - Não significativo.

No híbrido C 425 , os resultados de qui-quadrado encontrados foram significativos ao nível de $1 \%$ de probabilidade em todas as épocas de avaliação e no híbrido C 901 , houve significância dos desvios na avaliação realizada em espigas na pós colheita. Nestes casos os erros não foram devidos 
ao acaso e, sim, a outras causas como, por exemplo a ausência de características morfológicas diferenciais.

Comparando os resultados obtidos no teste de qui-quadrado (Tabela 10) com os das taxas de acerto e erro (Tabela 9), observou-se que nas épocas em que os desvios foram significativos, corresponderam aos de menores taxas de acerto. Assim, as características morfológicas permitem a identificação dos genótipos, com alto índice de acerto, e pode ser esperada a ocorrência de baixos valores de qui-quadrado, indicando variações aceitáveis entre os resultados obtidos pelos avaliadores. 


\section{CONCLUSÕES}

- Lotes de sementes do híbrido simples, apresentando contaminações com sementes provenientes do parental fêmea autofecundado, apresentam redução na qualidade fisiológica.

- Plantas provenientes de autofecundação apresentam-se mais baixas, com menor altura de espigas e menos produtivas do que as plantas híbridas.

- Redução no rendimento de grãos dos híbridos estudados, decorrente de contaminações com sementes dos parentais fêmeas autofecundados, depende, sobretudo, do rendimento das plantas provenientes de autofecundação, da capacidade de compensação das plantas híbridas e do local de semeadura.

- É possível separar, através de características morfológicas, as plantas provenientes de autofecundação das plantas híbridas. A fase de desenvolvimento mais adequada para avaliação da pureza genética das populações varia com o híbrido. 


\section{REFERÊNCIAS BIBLIOGRÁFICAS}

AIRY, J. Current problems of detasseling. In: ANNUAL CORN AND SORGHUM RESEARCH CONFERENCE, 5., Washington, 1950. Proceedings. Washington, American Seed Trade Association, 1950. p.717

ALLARD, R.W. Principios do melhoramento genético das plantas. São Paulo, Edgard Blucher, 1971. 381p.

ASSOCIATION OF OFFICIAL SEED ANALYSTS - AOSA. Seed vigor testing handbook. Lansing, 1983. 88p. (Contribution, 32).

BANZATTO, D.A. \& KRONKA, S.N. Experimentação agrícola. Jaboticabal, FUNEP, 1994. 247p.

BARROS, A.S.R. Maturação e colheita de sementes. In: SEMANA DE ATUALIZAÇÃO EM PRODUÇÃO DE SEMENTES, 1., Piracicaba, 1986. Trabalhos apresentados. Campinas, Fundação Cargill, 1986. p.107-34.

BASAVARAJAPPA, B.S.; SHETTY, H.S.; PRAKASH, H.S. Membrane deterioration and other biochemical changes, associated with accelerated ageing of maize seeds. Seed Science \& Technology, Zurich, 19:279-86, 1991. 
BATISTA, L.A.R. Uso de sementes autofecundadas e de polinização livre no melhoramento do conteúdo de óleo em duas subpopulações de milho (Zea mays L.). Piracicaba, 1981. 132p. (Doutorado- Escola Superior de Agricultura "Luiz de Queiroz"/USP)

BERNSTEIN, L. Hybrid vigor in corn and the mobilization of endosperm reserves. American Journal of Botany, Madison, 30:801-9, 1943.

BEWLEY, J.D. \& BLACK, M. Seeds; physiology of development and germination. New York, Plenum Press, 1985. 367p.

BRASIL. Ministério da Agricultura. Secretaria Nacional de Defesa Agropecuária. Regras para análise de sementes. Brasília, 1980. 188p.

BRINK, D.E.; PRICE, S.C.; NUGYEN, H.; FUREST, G.; MARTINEZ, C. Genetic purity assessment of commercial single cross maize hybrids: Isolelectric focusing of zeins. Seed Science \& Technology, Zurich, 17:91-8, 1989.

BRUCE, A.B. The mendelian theory of heredity and the augmentation of vigor. Science, Washington, 32:627-8, 1910.

BRUGGINK, H.; KRAAK, H.L.; DIJKEMA, M.H.G.E.; BEKENDAM, J. Some factors influencing electrolyte leakage from maize (Zea mays L.) Kernels. Seed Science Research, Wallingford, 1(1):15-20, 1991.

BURRIS, J.S. \& NAVRATIL, R.J. Relationship between laboratory cold-test methods and field emergence in maize inbreds. Agronomy Journal, Madison, 71:985-8, 1979. 
CAPELLARO, A.D. Comportamento de híbridos comerciais com diferentes origens. Uberlândia, Sociedade Agrícola Germinal Ltda, 1992. 4p.

CARDY, B.J. \& KANNENBERG, L.W. Allozymic variability among maize inbred lines and hybrids: Applications for cultivar identification. Crop Science, Madison 22:1016-20, 1982.

CARRARO, D.M. Variação e herança dos padrões eletroforéticos em grãos e estágios de desenvolvimento em milho (Zea mays L.). Piracicaba, 1990. 132p. (Mestrado- Escola Superior de Agricultura "Luiz de Queiroz"/USP).

CHEN, L.F.O. \& CHEN, L.C. Inheritance of two endosperm loc in rice (Oryza sativa L.). Theoretical and Applied Genetics, Berlin, 78:788-92, 1989.

CÍCERO, S.M. Mistura de lotes de diferentes idades e sua relação com a qualidade fisiológica e sanidade das sementes e desempenho das plantas de milho (Zea mays L.). Piracicaba, 1987. 119p. (Livre Docência - Escola Superior de Agricultura "Luiz de Queiroz"/USP).

COCCIOLONE, S.M. \& CONE, K.C. PL-BL, an anthocyanin regulatory gene of maize that leads to variegated pigmentation. Genetics, Princeton, 135:575-88, 1993.

COCHRAN, D.E. Progress of cytoplasmic and genetic sterility in hybrid seed corn production. In: ANNUAL CORN AND SORGHUM RESEARCH CONFERENCE, 30., Washington, 1975. Proceedings. Washington, American Seed Trade Association, 1975. p.116-30. 
CRAIG, W.F. Production of hibrid corn seed. In SPRAGUE, G.F. Corn and corn improvement. Madison, American Society of Agronomy, 1977. p. 671-9.

DAMEVAL, C.; HEBERT, Y.; VIENNE, D. Is the polymorphism of protein amounts related to phenotypic variabilitty? Acomparison of two dimensional electrophoresis data with morphological traits in maize. Theoretical and Applied Genetics, Berlin, 74:194-202, 1987.

DARWIN, C. Des effets de la fécondation croisé et de la fécondation direte la fégne végétal. Paris, C. Reinwald, 1877. 496p.

DELOUCHE, J.C. \& BASKIN, C.C. Accelerate aging techniques for predicting the relative storability of seed lots. Seed Science and Technology, Zurich, 1(2):427-52, 1973.

DITMER, W.P. Varietal determination made in the seed laboratory. Journal of Seed Technology, Zurich, 3(2):42-7, 1979.

DURÃES, F.O.M. Fatores ecofisiológicos afetando o comportamento de milho em semeadura tardia (safrinha) no Brasil central. Piracicaba, 1993. 91 p. (Doutorado - Escola Superior de Agricultura "Luiz de Queiroz"/USP).

DUVICK, D.N. Genetic and environmental interactions with cytoplasmic pollen sterility of corn. In: ANNUAL CORN AND SORGHUM RESEARCH CONFERENCE, 14., Washington, 1959. Proceedings. Washington, American Seed Trade Association, 1959. p.42-52. 
EAGLES, H.A. \& HARDACRE, A.R. Genetic variation in maize (Zea mays L.) for germination and emergence at $10^{\circ} \mathrm{C}$. Euphytica, Wageningen, 28:28795, 1978.

EAST, E.M. Heterosis. Genetics, Princeton, 21:375-97, 1936.

EBERHART, S.A. Yield stability of single cross genotypes. In: ANNUAL CORN AND SORGHUM RESEARCH CONFERENCE, 24, Washington, 1969. Proceedings. Washington, American Seed Trade Association, 1969. p. 22-35.

EBERHART, S.A. \& RUSSEL, W.A. Yield and stability for a 10 line diallel of single cross and double cross maize hybrids. Crop Science, Madison, 9:357-61, 1969.

EDNIE, A.B.; DHESI, N.S.; PAUKENS, J. Cultivar verification testing as an integral part of seed testing in Canada. Journal of Seed Technology, Lansing, 3(2):49-56, 1978.

FAKOREDE, M.A.B. \& AGBANA, S.B. Heterotic effects and association of seedling vigor with mature plant characteristics and grain yild in some tropical maize cultivars. Maydica, Bergamo, 28:327-38, 1983.

FEHR, W.R. Principles of cultivar development. New York, MacMillian Publ., 1987. v. 1, 736p.

FERREIRA FILHO, J.B.S. \& PERES, F.C. A produção de sementes de milho no Estado de São Paulo: Setor Público x Setor Privado. Revista Brasileira de Sementes, Brasília, 10(3):91-109, 1988. 
FRATIN, P. Comparação entre métodos para avaliação da qualidade fisiológica de sementes de milho (Zea mays L.). Piracicaba, 1987. 191p. (Mestrado Escola Superior de Agricultura "Luiz de Queiroz"/USP).

GILL, N.S. \& DELOUCHE, J.C. Determination of seed corn during storage. Proceedings of the Association of Official Seed Analysis, Lansing, 63(1):35-50, 1973.

GOODMAN, M.M. \& PATERNIANI, E. The races of maize. III. Choices of appropriate characters for racial classification. Economic of Botany, New York, 31:265-71, 1969.

GOODMAN, M.M. \& STUBER, C.W. Genetic identification of lines and crosses using isoenzyme electrophoresis. In: ANNUAL CORN AND SORGHUM RESEARCH CONFERENCE, 35., Washington, 1980. Proceedings. Washington, American Seed Trade Association, 1980. p.1030.

GUPTA, S.K. \& ROBBELEN, G. Identification of rapessed (Brassica napus) cultivars by electrophoresiss. Zeitschrift für Pflanzenzüchtung, Berlin, 96:363-70, 1986.

HAGEMAN, R.H.; LENG, E.R.; DUDLEY, J.W. A biochemical approach to corn breeding. Advances in Agronomy, New York, 19:45-85, 1967.

HALLAUER, A.R. \& MIRANDA FILHO, J.B. Heterosis. In: HALLAUER, A.R. \& MIRANDA FILHO, J.B. Quantitative genetics in maize breeding. Ames, Iowa State University Press, 1981a. p.337-73. 
HALLAUER, A.R. \& MIRANDA FILHO, J.B. Inbreeding. In: HALLAUER, A.R. \& MIRANDA FILHO, J.B. Quantitative genetics in maize breeding. Ames, Iowa State University Press, 1981b. p.299-336.

HALlAUER, A.R.; RUSSEL, W.A.; LAMKEY, K.R. Corn breeding. In: SPRAGUE, G.F. \& DUDLEY, J.W. Corn and corn improvement. 3.ed. Madison, American Society of Agronomy, 1988. v. 1, p.469-554.

HERTER, V. \& BURRIS, J.S. Evaluating drying injury on corn seed with a condutivity test. Seed Science \& Technology, Zurich, 17(2):625-38, 1989.

HOPPE, P.E. Cold testing. In: ANNUAL CORN AND SORGHUM RESEARCH CONFERENCE, 11., Washington, 1956. Proceedings. Washington, American Seed Trade Association, 1956. p.68-74.

HOPE, H.J.; WHITE, R.P.; DWYER, L.M.; MAAMARI, R.; SÉGUIN, S.; HAMILTON, R.I. Low temperature emergence potential of short season corn hybrids grown under controlled environment and plot conditions. Canadian Journal of Plant Science, Otawa, 72:83-91, 1992.

HUTCHCROFT, C.D. Contamination in seed fields of corn resulting from incomplete detasseling. Agronomy Journal, Madison, 51:267-71, 1959.

JOHNSON, I.J. \& MILLER, E.S. Immediate effect of cross pollination on the carotenoid pigments in the endosperm of maize. Cereal Chemistry, St. Joseph, 16:88-92, 1939. 
JOHNSON, D.R. \& TANNER, J.W. Comparisons of corn (Zea mays L.) inbreds and hybrids grown at equal leaf area index, light penetration and population. Crop Science, Madison, 12:482-485, 1972.

JONES, D.F. The produtiveness of single and double first-generation corn hybrids. Journal of the American Society of Agronomy, Washington, 14:241-52, 1922 .

JOSEPHSON, L.M.; MORGAN, T.E.; ARNOLD, J.M. Genetics and inheritance of fertility restoration of male-sterile cytoplasms in corn. In: ANNUAL CORN AND SORGHUM RESEARCH CONFERENCE, 33., Washington, 1978. Proceedings. Washington, American Seed Trade Association, 1978. p. $48-59$.

JUGENHEIMER, R.W. Hybrid maize breeding and seed production. FAO Agricultural Delopment Paper, Rome 62:157, 1958.

JUGENHEIMER, R.W. Obtención de maiz hibrido y producción de semila. Roma, FAO, 1959. 395p.

KEEBLE, F. \& PELLEW, C. The mode of inheritance of stature and time of flowering in peas. Journal of Genetics, Calcutta, 1:47-56, 1910.

KORANYI, P. Characterisation of maize (Zea mays L.) seed samples by the eletrophoretic patterns of their protein monomers, Seed Science \& Technology, Zurich, 10:153-9, 1989.

KRZYZANOWSKI, F.C. \& FRANÇA NETO, J.B. Situação atual do uso de testes de vigor como rotina em programas de sementes no Brasil. In: 
WORKSHOP BRASILEIRO DE CONTROLE DE QUALIDADE DE SEMENTES, 1., Lavras, 1991. Lavras, ESAL, ABRATES, 1991. n.p.

LIN, S.S. \& PEARCE, R.S. Changes in lipids of bean seeds (Phaseolus vulgaris) and corn caryopses (Zea mays L.) aged in contrasting environments. Annals of Botany, London, 65:451-6, 1990.

LOPEZ-PEREZ, E. Comparisons among maize hybrids made from unselected lines developed by selfing and full-sibbing. Ames, 1977. 91p. (M.S. - Iowa State University).

LOWENBERG, D.H. Impact of purity on ultimate hybrid performance. Aurora, Cargill, 1986. 3p.

MANGELSDORF, A.J. The effects of a lethal on the heterozygote in maize. Journal of Heredity., Washington, 19:123-31, 1928.

MARCOS FILHO, J. Teste de envelhecimento acelerado. In: VIEIRA, R.D. \& CARVAlHo, N.M. de. Testes de vigor em sementes. Jaboticabal, FUNEP, 1994. p.133-49.

MARCOS FILHO, J.; CICERO, S.M.; SILVA, W.R. DA. Avaliação da qualidade das sementes. Piracicaba, ESALQ, 1987. 230p.

MARYAM, B. \& JONES, D.A. The genetics of maize (Zea mays L.) growing at low temperatures. Germination of inbred lines and their F1s. Euphytica, Wageningen, 32:535-42, 1983.

McClUER, G.W. Corn crossing III. Agr. Exp. Sta., 1892. n.p. (Bulletin, 12). 
McDONALD Jr., M.B. The influence of seed moisture the accelerated aging seed vigor test. Journal of Seed Technology, Lansing, 2(1):18-28, 1977.

McDONALD Jr., M.B. Assessment of seed quality. Hort Science, Alexandria, 15(6):784-8, 1980.

McDONALD Jr., M.B. Validation of starch gel electrophoresis for corn seed purity determinations. In: ANNUAL CORN AND SORGHUM RESEARCH CONFERENCE, 45., Washington, 1990. Proceedings. Washington, American Seed Trade Association, 1990. p.43-53.

MIRANDA FILHO, J.B. \& VIEGAS, G.P. Milho híbrido. In: PATERNIANI, E. \& VIEGAS, G.P., ed. Melhoramento e produção do milho. 2. ed. Campinas, Fundação Cargill, 1987. v.1, p.277-340.

NUCCA, R. SOAVE, C.; MOTTO, M.; SALAMINI, F. Taxonomic significance of the zein isoeletric focusing pattern. Maydica, Bergamo, 23:239-49, 1978.

ODIEMAH, M. Relation of seed testing traits to grain yield of maize hybrids under different environments. Seed Science \& Tecnology, Zurich, 19:2532,1991 .

ORMAN, B.A.; LAWRANCE, G.D.; DOWNES, P.M.; PHILliPS, D.S.; RIPBERGER, C.J. Assessment of maize inbred genetic purity by isozyme eletrophoresis. Seed Science \& Technology, Zurich, 19:527-53, 1991.

OTTOBONI, L.M. \& STEFFENSEN, O.M. Localization of zein genes in maize. Biochemical Genetics, New York, 25:123-42, 1989. 
PALEG, L.G. Physiological effects of gibberellins. Annual Review of Plant Physiology, Palo Alto, 16:291-322, 1965.

PAUKSENS, J. Field testing of hybrid corn for trueness to variety. Proceedings of the Association of Official Seed Analysts, Lansing, 50:63-5, 1960.

PAUKSENS, J. Methods for determination of cultivar trueness and purity in maize (Zea mays L.). Seed Science \& Technology, Zurich, 3(1):176-85, 1975.

PAUKSENS, J. Determination of cultivar. Seed Science \& Technology, Zurich, 6:579-83, 1978.

PAUKSENS, J. \& DHESI, N.S. Cultivar verification methods used in Canada. Seed Science \& Technology, Zurich, 6:585-92, 1978.

PAYNE, R.C. Variety testing by official AOSA seed laboratories. Journal of Seed Technology, Lansing, 10(1):24-36, 1986.

PESEY, N.V. Genetic factors affecting maize tolerance to low temperatures at emergence and germination. Theoretical and Applied Genetics, Berlin, 40(8):350-6, 1970.

PIMENTEL GOMES, F. Curso de estatística experimental. 12. ed. Piracicaba, ESALQ/USP, Editora Nobel, 1987. 466 p.

PINTÉR, L. Effect of genetic contamination on maize yield (Zea mays L.). Zeitschrift für Pflanzenzüchtung, Berlin, 93:101-5, 1984. 
POPINIGIS, F. Aspectos da qualidade de sementes. Curso para técnicos responsáveis por lavouras de produção de sementes. Documentos. CETREISUL, Pelotas, 2:354-70, 1975.

POPINIGIS, F. Fisiologia da semente. Brasília, Ministério da Agricultura, AGIPLAN, 1985. 289p.

RAMALHO, M.A.; SANTOS, J.B.; PINTO, C.B. Genética na agropecuária. Lavras, FAEPE, 1990. 359p.

RAYNOR, G.S.; OGDEN, E.C.; HAYES, J.V. Dispersion and deposition of corn pollen from experimental sources. Agronomy Journal, Madison, $64: 420-7,1972$.

RHOADES, M.M. The cytoplasmic inheritance of male sterility in Zea mays. Journal of Genetics, Calcutta, 27:71-93, 1933.

RICHEY, F.D. The experimental basis for the present status of corn breeding. Jouranl of American Society of Agronomy, Washington, 14:1-17, 1922.

RINKE, E.H. Cold test germinations. In: ANNUAL CORN AND SORGHUM RESEARCH CONFERENCE, 8, Washington, 1953. Proceedings. Washington, American Seed Trade Association, 1953. p.54-68.

ROGERS, J.S \& EDWARDSON, J.R. The utilization of cytoplasmic male sterile inbreds in the production of corn hybrids. Agronomy Journal, Madison, 44:8-13, 1952.

ROOD, S.B.; BLAKE, T.J. ; PHARIS, R.P. Gibberellins and heterosis in maize. II. Response to gibberellic acid and metabolism of $\left[{ }^{3} \mathrm{H}\right] \mathrm{GA}_{20}$. Plant Physiology, Maryland, 71:645-51, 1983. 
ROOD, S.B.; BUZZELL, R.I.; MAJOR, D.J.; PHARIS, R.P. Gibberellins and heterosis in maize: Quantitative relationships. Crop Science, Madison, $30: 281-6,1990$.

RUSSEL, W.A. Comparative performance for maize hybrids representing different areas of maize breeding. In: ANNUAL CORN AND SORGHUM RESEARCH CONFERENCE, 29, Washington, 1974. Proceedings. Washington, American Seed Trade Association, 1974. p.81-101.

RUSSEL, W.A. \& HALlaUER, A.R. Corn. In: FEHR, W.R. \& HADLEY, H.H. Hybridization of crop plants. Madison, American Society of Agronomy and Crop Science Society of America, 1980. p.299-311.

SCANDALIOS, J.G.; LIU, E.H.; CAMPEAU, M.A. The effects of intragenic and intergenic complementation on catalase structure and function in maize. A molecular approach to heterosis. Archives and Biochemistry and Biophysics, San Diego, 153:695-705, 1972.

SCHELL, L.P.; DANEHOWER, D.A.; ANDERSON, J.R.; PATTERSON, R.P. Rapid isolation and measurement of adenosine triphosphate levels in corn embryos germinated at suboptimal temperatures. Crop Science, Madison, 31:425-30, 1991.

SCHMIDT, J.W. A plant breeder looks at the problem of distinguishing varieties. Journal of Seed Technology, Lansing, 3(2):57-60, 1979.

SCHNELL, F.W. Type of variety and average performance in hybrid maize. Zeitschrift fur Pflanzenzüchtung, Berlin, 74:177-88, 1975. 
SCHWARTZ, D. \& LAUGHNER, W.J. A molecular basis for heterosis. Science, Washington, 166:626-7, 1973.

SHULL, G.H. A pure-line method in corn breeding. American Breeders Association Report, Washington, 5:51-9, 1909.

SHULL, G.H. The genotypes of maize. American Naturalist, Chicago, 45:234-52, 1911.

SHULL, G.H. Hybrid seed corn. Science, Washington, 103:547-50, 1946.

SINGH, N.N. \& SARKAR, K.R. Anthocyanin pigmentation in various parts of the maize plant in relation to line development and seed certification. Seed Reseach, New Delhi, 10(1):18-26, 1982.

SMITH, J.S.C. \& SMITH, O.S. Association among inbred lines of maize using eletrophoretic chromatografic and pedigree data. Theoretical and Applied Genetics, Berlin, 73:654-64, 1987.

SMITH, J.S.C. \& SMITH, O.S. The description and assessment of distances between inbred lines of maize: II. the utility morphological, biochemical and genetic descriptors and scheme for the testing of didtinctiveness between inbred lines. Maydica, Bergamo, 34:151-61, 1989.

SMITH, S. \& WEISSINGER, H. Rapid monitoring of purity in seed lots of hybrid maize: Modifications of current technologies. Maize Genetics Cooperation News Letter, Bloomington, 58:103-5, 1984.

SMITH, J.S.C. \& WYCK, R.D. The identification of female selfs in hybrid maize: a comparison using electrophoresis and morphology. Seed Science \& Technology, Zurich, 14:1-4, 1984. 
SRIVASTAVA, J.M. \& AGRAWAL, B.D. Phenotypic variability in parental lines of some released maize hybrids. Seed Research, New Delhi, 13(1):8$15,1985$.

STUBER, C.W.; WENDEL, J.F.; GOODMAN, M.M. \& SMITH, J.S.C. Techiniques and scoring procedures for starch gel electrophoresis of enzymes from maize. Raleigh, North Carolina State University, 1988. 87p. (Technical Bulletin, 286)

STYLES, E.D. Extending the expression of self-color R1-scm alleles in maize. Maydica, Bergamo, 38:127-33, 1993.

SURESH, K.S. \& HANNA, R. Physiological, biochemical and genetic basis of heterosis. Advances in Agronomy, New York, 27:123-75, 1975.

TAFURI, F. IAA determination in the kernels of four lines of corn and their hybrids. Phytochemistry, Oxford, 5:999-1003, 1966.

TATUM, L.A. \& ZUBER, M.S. Germination on maize under adverse conditions. Journal of the American Society of Agronomy, Washington, 35(1):48-59, 1943.

TAVARES, F.C.A. Componentes de produção relacionados à heterose em híbridos intervarietais de milho (Zea mays L.). Piracicaba, 1972. 106p. (Doutorado- Escola Superior de Agricultura "Luiz de Queiroz"/USP).

TEKRONY, D.M. Seed vigor testing. Journal of Seed Technology, Lansing, $8(1): 55-60,1983$. 
TEKRONY, D.M. \& EGLI, D.B. Relationship between laboratory indices of soybean seed vigor and field emergence. Crop Science, Madison, 17(4):573-7, 1977.

VAN DER WERF, H.M.G.; HOEK, J. \& SOEPBOER, M.J. Undersired selfpollination of the parent plant decreases dry matter yield of silage maize. Journal of Agronomy \& Crop Science, Lelystad, 162:43-8, 1989.

VIEGAS, G.P. \& MIRANDA FILHO, J.B. Milho híbrido. In PATERNIANI, E. Melhoramento e produção do milho no Brasil. Campinas, Fundação Cargill, 1978. p.257-309.

VIEIRA, R.D. Teste de condutividade elétrica. In: VIEIRA, R.D. \& CARVAlHO, N.M. de. Testes de vigor em sementes. Jaboticabal, FUNEP, 1994. p. 103-32.

WEATHERSPOON, J.H. Comparative yields of single, three-way, and double cross of maize. Crop Science, Madison, 10:157-9, 1970.

WHALEY, W.G. The growth of inbred and hybrid maize. Growth, Lakeland, 14:123-54, 1944.

WRIGHT, H. Commercial hybrid seed production. In: FEHR, W.R. \& HADLEY, H.H. Hybridization of crop plants. Madison, American Society of Agronomy and Crop Science Society of America, Madison, 1980. p.162-76.

WYCK, R.D. Prodution of hybrid seed corn. In: SRAGUE, G.F. \& DUDLEY, J.W. Corn and corn improvement. 3. ed. Madison, American Socity of Agronomy, 1988. p. 565-607. 
ZONTA, E.P.; MACHADO, A.A.; SILVEIRA, P. Sistema de análise estatística para microcomputadores - SANEST. Pelotas, UFPEL, 1984. (disquete). 


\section{APÊNDICE}




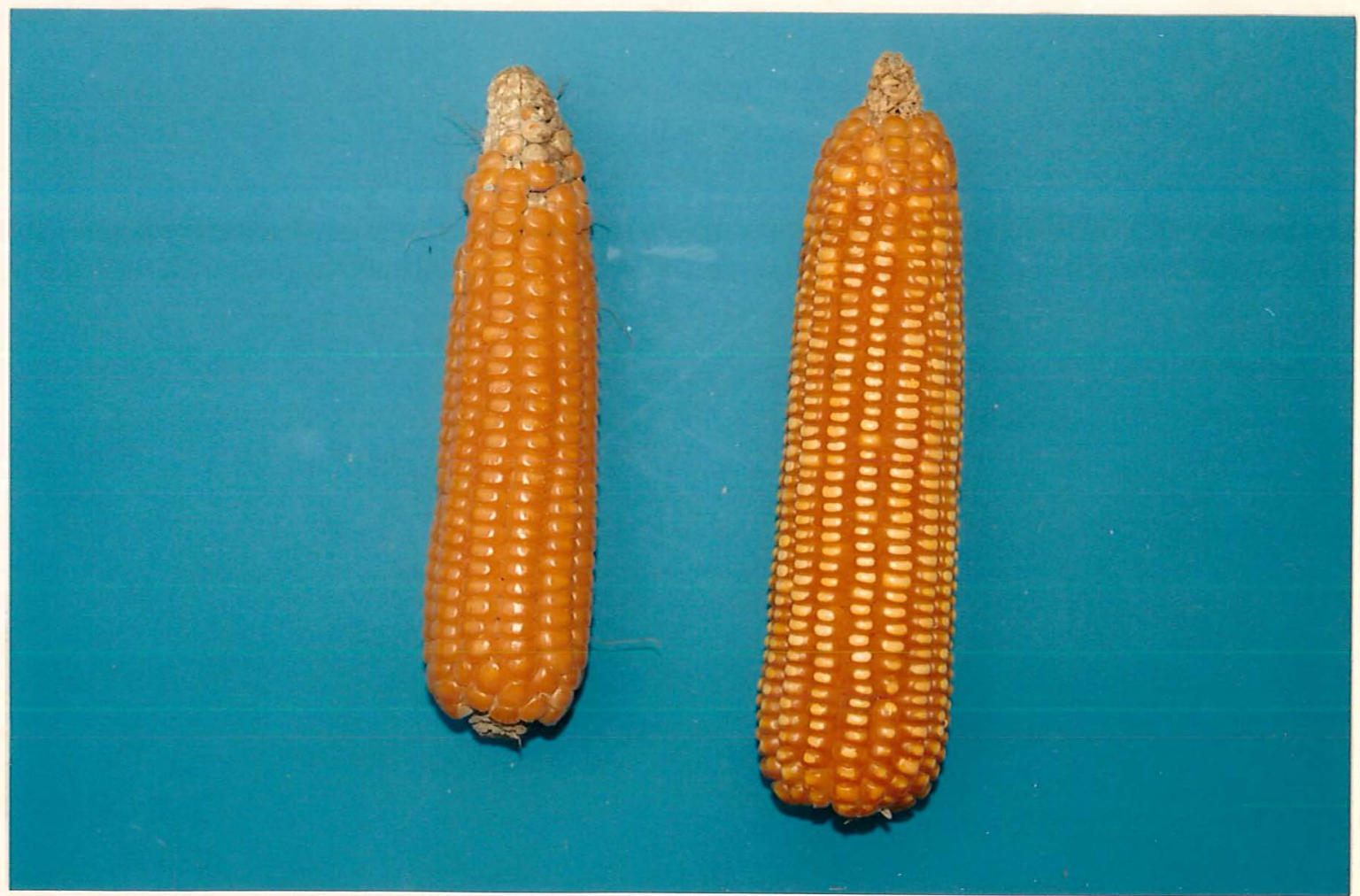

Figura 1a. Espigas oriundas de plantas provenientes do parental fêmea autofecundado (esquerda) e de plantas híbridas (direita), do híbrido C 701.

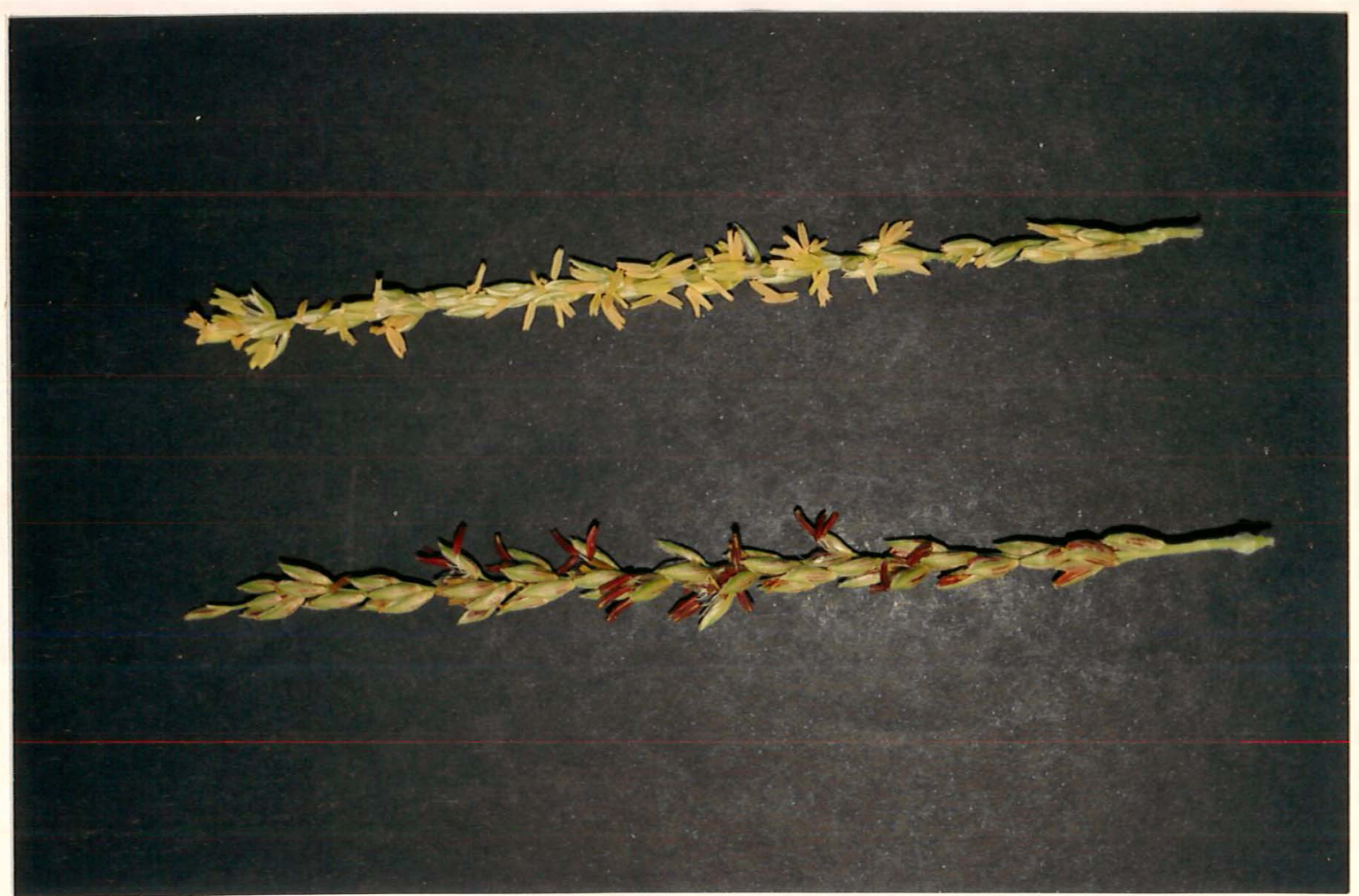

Figura 2a. Pendões com anteras oriundos de plantas provenientes do parental fêmea autofecundado (inferior) e de plantas híbridas (superior), do híbrido C 701 . 


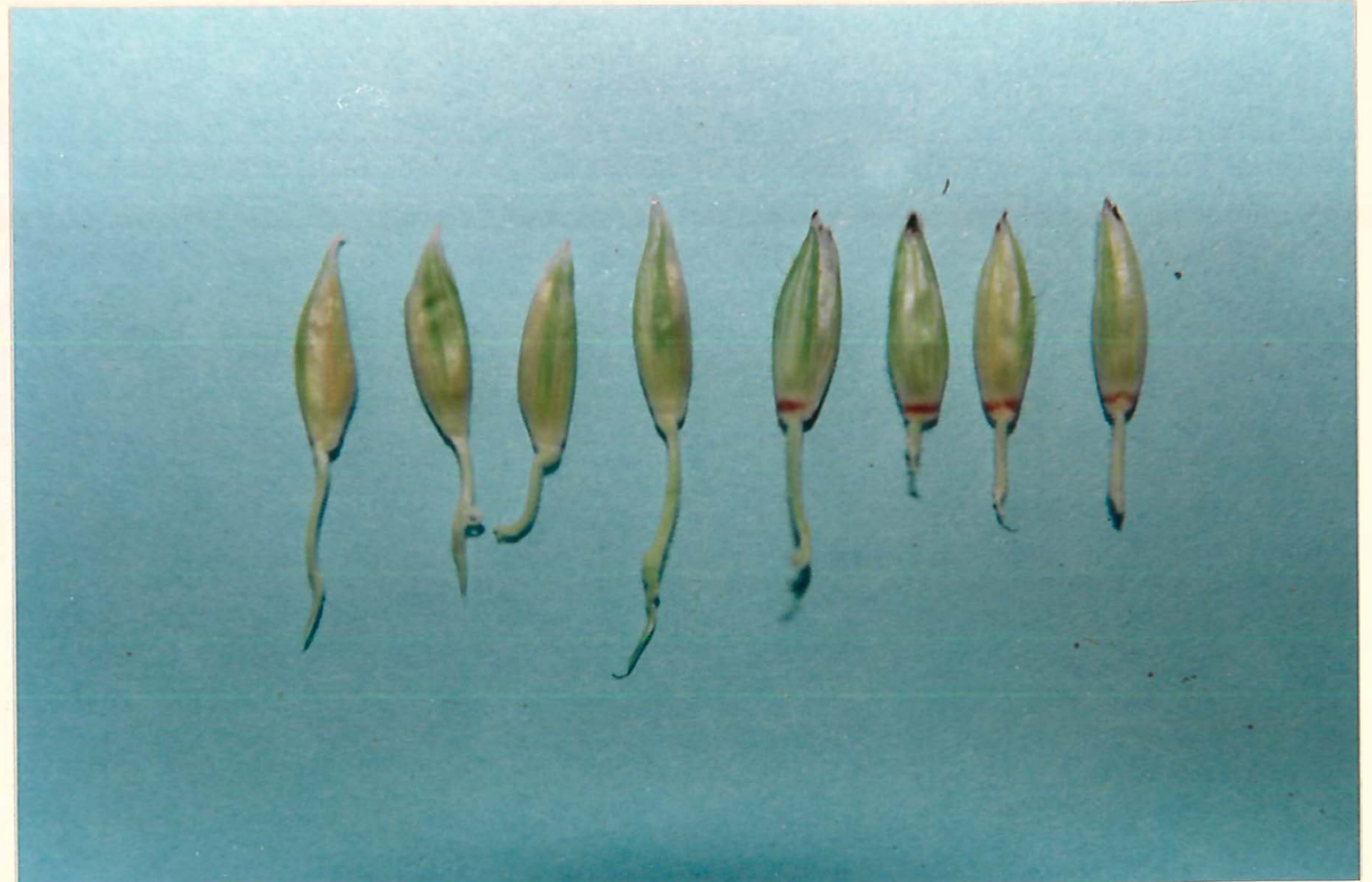

Figura 3a. Glumas oriundas de pendões de plantas provenientes do parental fềmea autofecundado (direita) e de plantas híbridas (esquerda), do híbrido C 701.

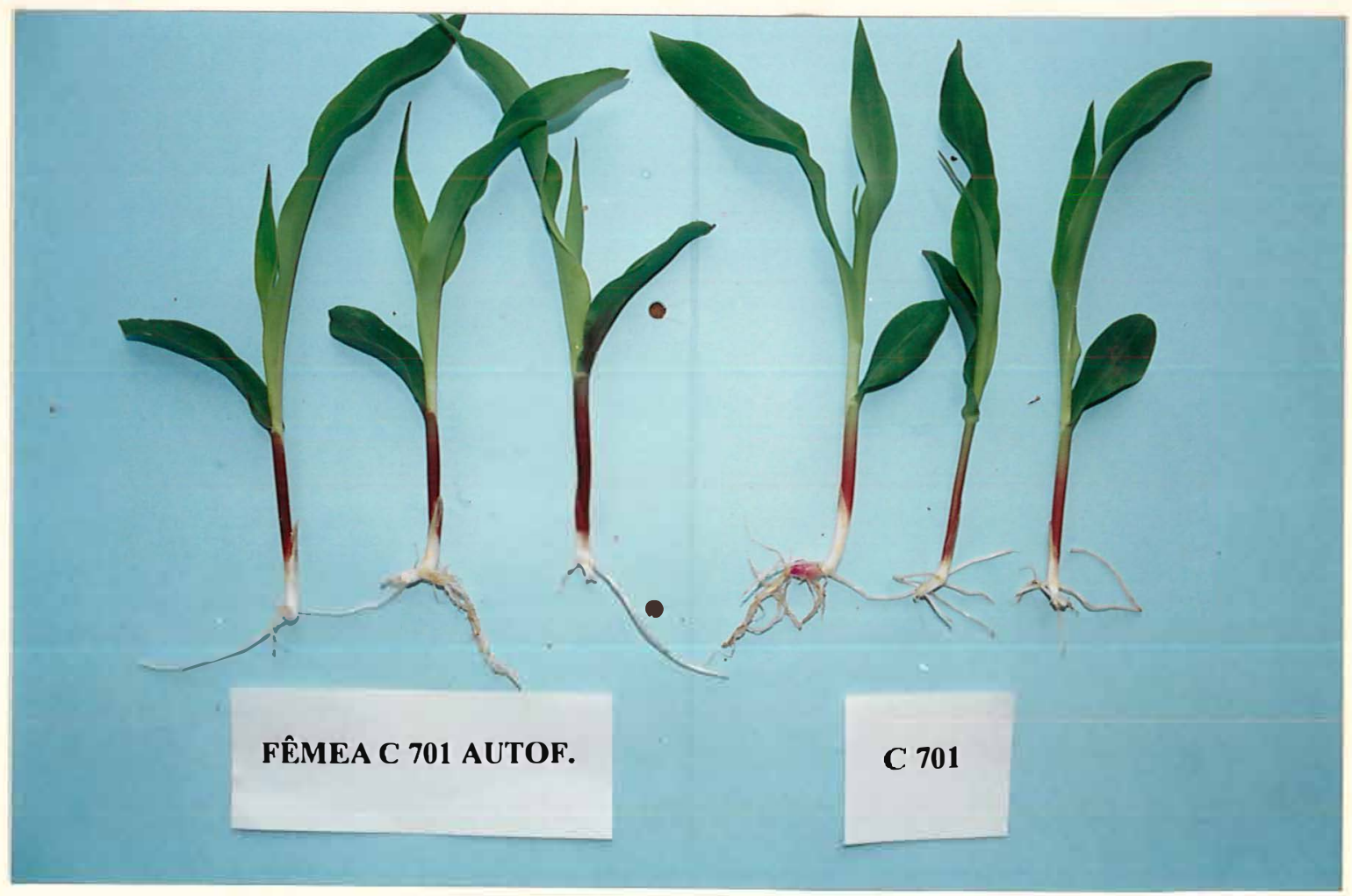

Figura 4a. Plântulas oriundas de sementes provenientes do parental fềmea autofecundado (esquerda) e de sementes híbridas (direita), do híbrido C 701. 


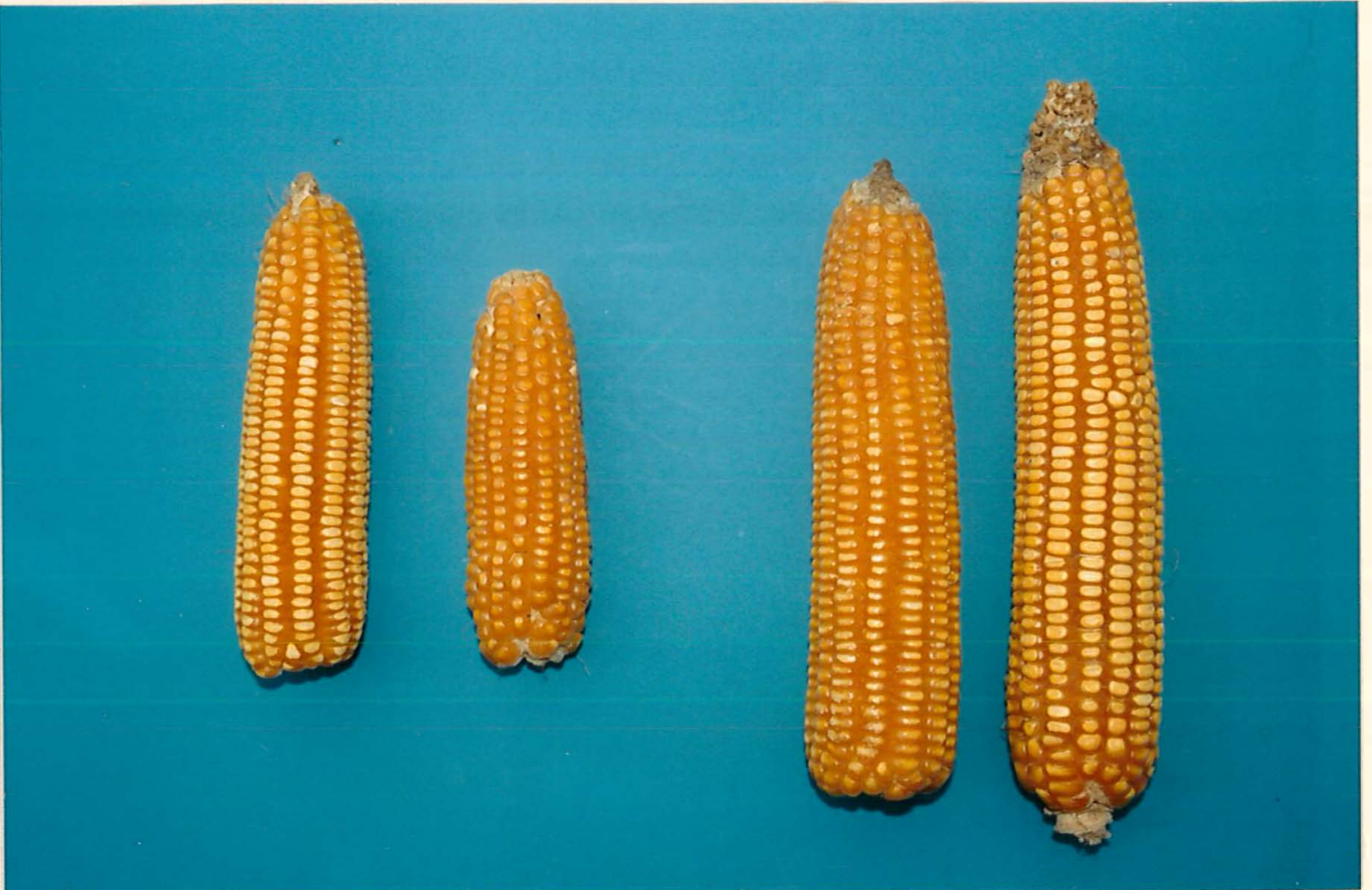

Figura 5a. Espigas oriundas de plantas provenientes do parental fềmea autofecundado (esquerda) e de plantas híbridas (direita), do híbrido C 425.

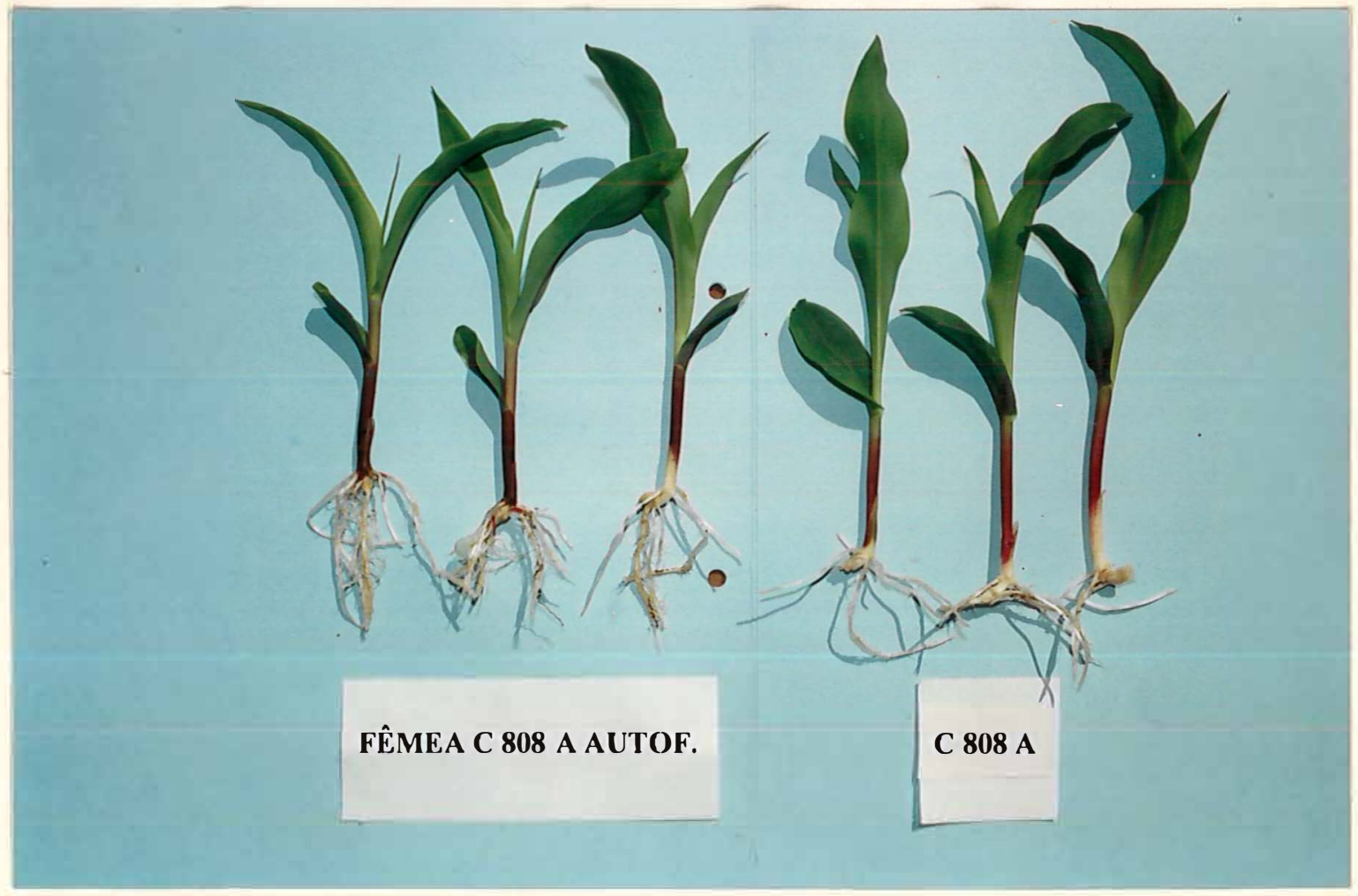

Figura 6a. Plântulas oriundas de sementes provenientes do parental fềmea autofecundado (esquerda) e de sementes híbridas (direita), do híbrido C $808 \mathrm{~A}$. 


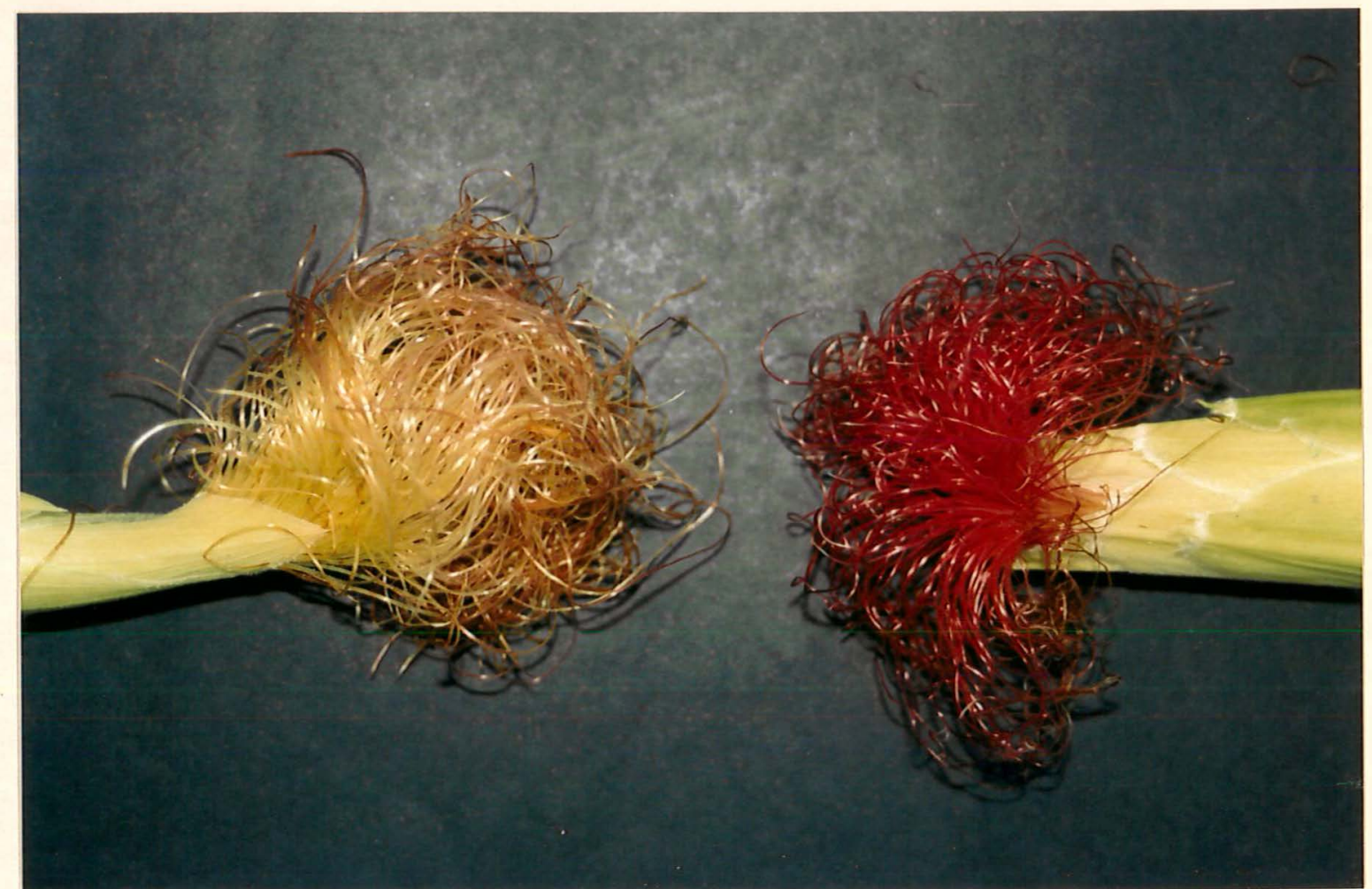

Figura 7a. Estilo-estigmas oriundos de espigas de plantas provenientes do parental fêmea autofecundado (direita) e de plantas híbridas (esquerda), do híbrido C $808 \mathrm{~A}$.

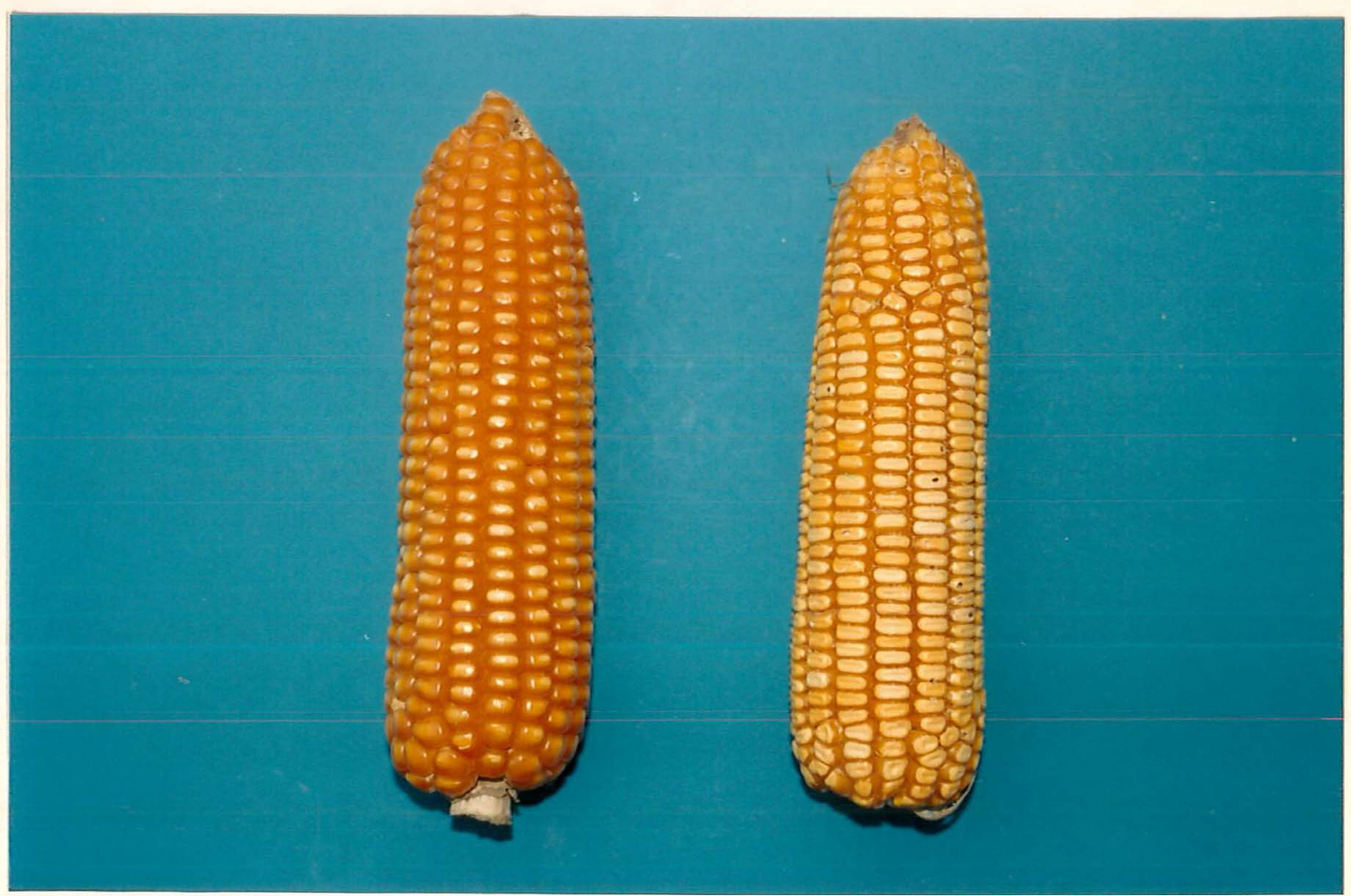

Figura 8a. Espigas oriundas de plantas provenientes do parental fêmea autofecundado (esquerda) e de plantas híbridas (direita), do híbrido C $808 \mathrm{~A}$. 


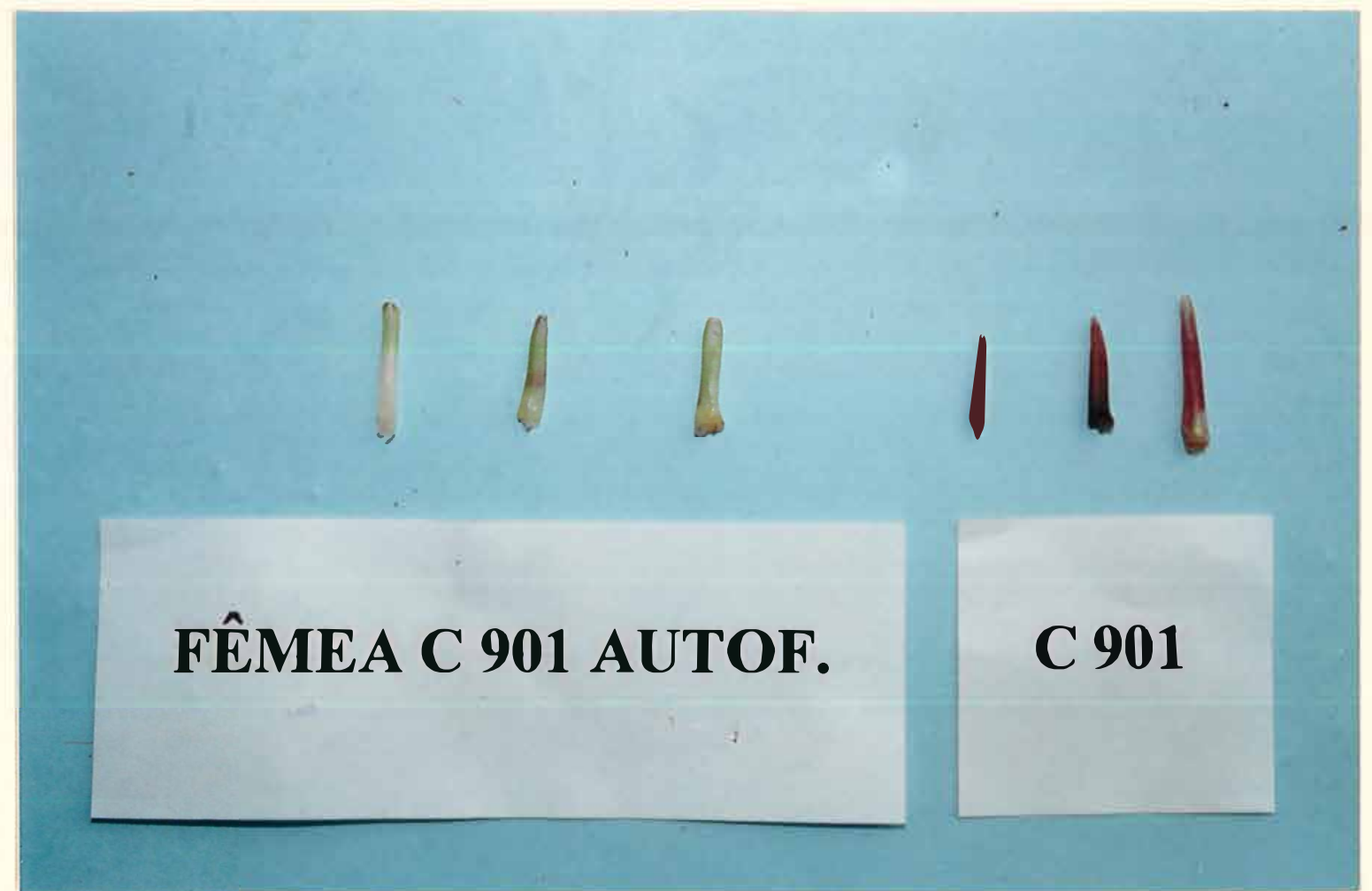

Figura 9a. Coleoptilos oriundos de plântulas provenientes do parental fềmea autofecundado (esquerda) e de plântulas híbridas (direita), do híbrido C 901.

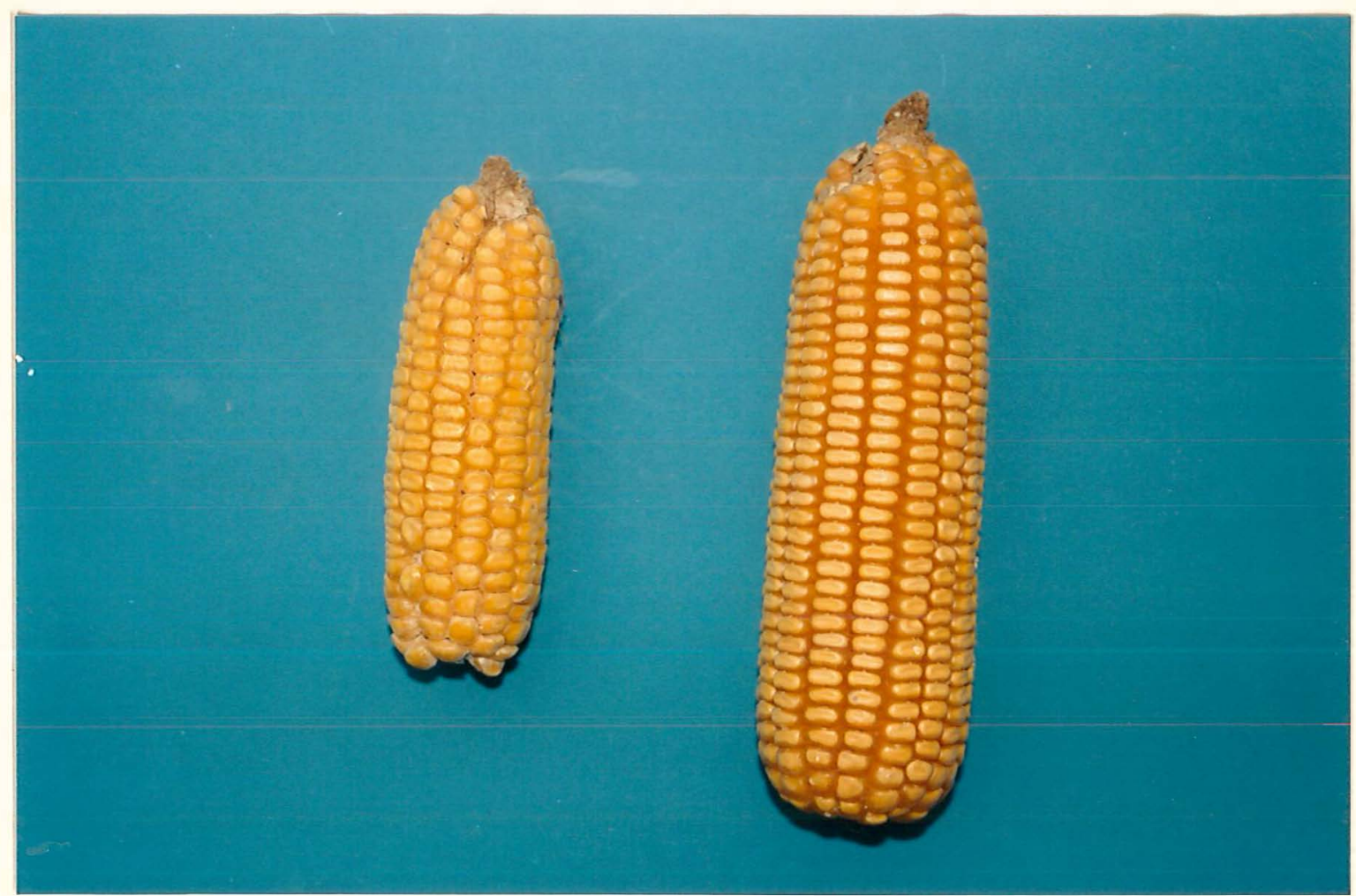

Figura 10a. Espigas oriundas de plantas provenientes do parental fêmea autofecundado (esquerda) e de plantas híbridas (direita), do híbrido C 901. 